NBER WORKING PAPER SERIES

\begin{abstract}
UNOBSERVABLE FAMILY AND INDIVIDUAL CONTRIBUTIONS TO THE DISTRIBUTIONS OF INCOME AND WEALTH
\end{abstract}

$$
\text { J. R. Kearl }
$$

Clayne L. Pope

Working Paper No. 1425

\author{
NATIONAL BUREAU OF ECONOMIC RESEARCH \\ 1050 Massachusetts Avenue \\ Cambridge, MA 02138 \\ August 1984
}

\begin{abstract}
Prepared for the Smith Conference on Economics and Public Policy. Research supported by the National Science Foundation Grant \#SES 8218799 NSF and by the College of Social Science, Brigham Young University. The research reported here is part of the NBER's research program in Development of the American Economy. Any opinions expressed are those of the authors and not those of the National Bureau of Economic Research.
\end{abstract}


Unobservable Family and Individual Contributions to the Distributions of Income and Wealth

\section{ABSTRACT}

This paper uses a data set composed of combinations of full brothers, half brothers as well as fathers and sons to measure the effect of common family background on households' income and wealth. While the data is drawn from a nineteenth century population, the intra-class correlation (after the effects of age, occupation, nativity, residence and duration in the economy have been removed) for income ranges from .13 to.18 which is similar to that found in modern samples. Intra-class correlations for wealth are significantly higher (.18 to .35) than those for income. The addition of fathers' observed characteristics to the sweeping regressions reduces the unobserved common background effect shared by brothers by about twenty percent.

The intra-class correlations of half brothers were lower than those observed for full brothers though the small differences between the two groups suggest that fathers played a dominant role in the transmission of the common family effect. Unobserved background was decomposed into individual and family effects by a variance components procedure. The individual effect was dominant for income while the family effect was dominant for wealth.

J. R. Kearl

Department of Economics 184 Faculty office Building Brigham Young University Provo, UT 84602
Clayne L. Pope

Department of Economics

184 Faculty Office Building

Brigham Young University

Provo, UT 84602 
Family members, except perhaps spouses, are certainly genetically and highly likely to be environmentally more similar than unrelated individuals. This unobserved common background may very well make family members more similar in measured socioeconomic position than would be expected for unrelated individuals with comparable observable individual characteristics. In addition, if parents are egalitarian within the family, they may make compensatory transfers in response to differences among siblings. Parental choices of this sort would ai so make sibilings more similar than comparable unrelated individuals in terms of socioeconomic outcomes. In the first instance, family members are more socioeconomically alike because of similarities in backgrounds and characteristics.

In the second instance family members are more socioeconomically alike because dissimilarities in sibling characteristics trigger compensatory activities by parents.

On the other hand, efficient parental human capital transfers to children would not ameliorate the economic effects of ability differences among siblings assuming ability enhances human capital acquisition. The effect of the family on the distribution of socioeconomic rewards depends, then, on the variation in individual characteristics within and between families, market rewards for those characteristics and the rules of family allocation of parental resources among children (see Becker and Tomes; Behrman, Pollak and Taubman; Ishikawa; Loury; and Sheshinski and Weiss). Behrman, Pollak and Taubman distinguish two allocational models: the wealth model and the separable earnings-bequest model. If there are positive material wealth transfers, the former predicts that such transfers fully compensate for earnings differences. The separable earnings-bequest model predicts equal transfers. Children may, in either 
case, have different expected earnings if they have different abilities even if parents have equal concern for their children.

Failure to account for common family background effects may bias estimates of the effects of measured individual characteristics (e.g. the return to education). Considerable effort has been devoted to this problem using sibling data although Sheshinski and Weiss argue that the importance of the bias depends upon the family resource allocation rule. Moreover, whether the use of sibling data lessens or amplifies bias probiems depends on whether the common family effect fully accounts for all ommitted effects and on the possibility of measurement error and simultaneity problems. (See Griliches, 1979.) Common family background effects are, however, interesting in their own right precisely because of the importance of the family resource allocation rule and its embedded parental preferences. In addition, failure to account for such effects would lead one to overestimate the degree to which the variance in observable socioeconomic indicators is truly stochastic, unless common family background is completely reflected in the observable characteristics that individuals have or choose to acquire. If the potential effects of family background are not completely reflected in observable individual characteristics, ignoring family background may cause one to overlook important aspects of the creation and perpetuation of economic differences among individuals and across generations. Even where the effects are fully or partially reflected in observable individual characteristics, we may view these individual characteristics differently knowing that, in part, they embody a family background shared with other individuals. Finally, if common family background effects are substantial, they may affect greatly policy development aimed at changing the distribution of socioeconomic rewards among individuals since the family then becomes an important 
social institution affecting the distribution of socioeconomic rewards in addition to the government.

In this paper we explore the degree to which family background, whose source may be genetic, environmental and/or behavioral, explains the variance in indicators of socioeconomic position for individuals from an economy that would appear to be quite different from the economy from which modern data are drawn -- 19th century Utah. Our data allow us to consider two different kinds of family relationships, that between fathers and their sons and that between brothers. For the latter, we have samples of full brothers raised in the same home sharing a common father and mother and half brothers raised in separate homes sharing only a common father. We use two indicators of socioeconomic position, wealth holdings and income.

We focus on those aspects of common family background that are not measured directly but whose presence can be inferred from correlations between the observed socioeconomic positions of family members when the effects of individual characteristics have been factored out. We also consider the differences between measured and unmeasured common background by accounting for the observed individual characteristics of a common father, including the father's income or wealth, and for the characteristics of the common family such as family size.

Families can, of course, influence individual choices about individually acquired characteristics. However, in a series of studies over the past several years, it has been found that when the effects of individual characteristics have been accounted for there remains an unmeasured component of the variance in measures of socioeconomic position that can be attributed to membership in a common family by siblings. That is, residuals are correlated when individuals 
are ordered by family membership. For example, Table 1, combined from the summary work of Jencks and his associates and from a survey by Griliches, provides the intraclass correlation coefficients for eight recent studies using sibling data. The intraclass correlation coefficient, which measures the degree of association between individuals who share the attribute of belonging to the same family, also measures the percentage of the variance in the socioeconomic indicator that can be attributed to the common characteristic, in this case family membership. The indicator in these studies is the logarithm of income or earnings al though many of the studies also use occupational status as an indicator.

For each of the samples of brothers, there is a residual correlation that is significant. That is, brothers are unlike randomly paired individuals in their economic position as measured by income. In addition, the variance that can be explained by sibling membership in a common family exceeds that which can be explained by observable individual characteristics -- common family background dominates other measured determinants of a brother's income. Jencks argues that the NORC sample provides the best estimate of the intraclass correlation $(r=.129)$ and that the range of raw estimates of $r$ is likely to be .12 to .28 . That is, family background explains 12 to 28 percent of the variance in the logarithm of income. When suitable adjustments are made for sample and measurement bias, Jencks et al. argue that family background probably explains between 15 and 35 percent of the variance of log income -- a significant addition to the variance explained by observable individual characteristics.

Brittain, using a small sample of brothers from Cleveland, finds a much higher intraclass correlation for log income than any of the studies summarized by Jencks et al. He estimates an intraclass correlation in the $.35-.45$ range 
but his is the only study with estimates this high. The intraclass correlation for occupational status measured by the Duncan scale is still higher, around .48. This may be attributable, in part, to the way that the status measure is created. But in any event, the correlation attributable to family background again exceeds that explainable by individual characteristics ( $R^{2}$ is usually in the .20 to .35 range for occupational status).

The substantial difference that Taubman finds between monozygote and dizygote twins has led him and his associates to explore models that separate the common family background effect into genetic and environmental components. Goldberger has been skeptical of the assumptions necessary to pursue this approach but potential problems in modelling the nature of the family background effect do not call into question the presence of the family effect itself.

Chamberlain, Griliches and others have explored the possibilites that there is a common factor accounting for the family effect in a structural model of ability, schooling, occupational status and $\log$ income, taking advantage of the identifiability properties of multiple indicators for latent variable models. Chamberlain and Taubman et al. have extended the latent variable model so that the unobserved factor has a variance components structure. These efforts have been quite successful in changing the estimates of the returns to schooling but less successful in pushing the various estimates toward a common point. Chamberlain and Griliches have also explored extensions of these models to include the possibility that there are two factors that account for the family effect.

Our aim is initially more modest: Using single equation models, we estimate the variance component or the intraclass correlation attributable to individuals sharing a common family background and explore how the estimates differ with 
6

the nature of the socioeconomic indicator, the nature of the family relationship and the nature of family background measures available. We also consider differences between unobserved individual and family effects.

\section{THE DATA}

Our data are drawn from some or all of the following sources: census manuscripts of $1850,1860,1870,1880$ and 1900; tax assessment records of 1870 , 1880, 1890, and 1900; financial records of the LDS Church for 1855, 1857, $1859,1861,1866,1870,1875,1880,1885,1890,1895,1900$; and family vital records from the Genealogical Library of the LDS Church.

Estimates of wealth were obtained from the Census manuscripts of 1850 , 1860 and 1870 and from tax assessment records for 1870, 1880, 1890 and 1900 . We sampled from both records in 1870 in order to splice the wealth series from 1850 to 1900 at decade intervals. Both tax assessment and census records provide estimates of gross rather than net wealth.

Income estimates are obtained from the financial records of the LDS Church for the 12 years noted earlier. Essentially we cover five year intervals from 1855 to 1900. LDS financial records indicate the contribution an individual made to the Church. Church members accepted the moral obligation to contribute a tithe--ten percent of one's income. In eight of the twelve sample years we have a record of the percentage that an individual's contribution was relative to this full tithe. These assessments of tithing paid versus tithing owed were made by local Church leaders who would personally know the individual contributor. The individual would also be consulted as to the percentage of a full tithe that he or she paid. Families usually made their contribution under the name of the male spouse if there was one although some young men 
contributed independently to the Church. The combination of the amount contributed with the percentage of this amount relative to a full tithe yields an estimate of income. We made adjustments for who those reported income in a particular year but for whom we did not have percentages by averaging the percentage paid from other years.

Occupational data have been collected from each census manuscript, available from 1850 to 1900. Occupations were transcribed into a three-digit code that combined occupations that were essentiaity the same, e.g. lawyer and attorney. We did not create an occupational status scale. Rather, for purposes of analysis, these codes were aggregated into four categories: white collar workers, managers, and proprietors (W); farmers, ranchers, dairy owners, etc. (F); craft workers (C); laborers, farm laborers and other unskilled occupations (L). This left a heterogeneous mixture of occupations that were largely service oriented, such as hotel clerks, policemen, lower level clerks, etc. which we classified in a fifth group as service workers (S).

Both census and genealogical records provide place of birth and age. When these sources disagreed, the genealogical record was used. From these two records we could obtain most of the vital statistics of interest, including birth, death and marriage information as well as the implied information about household location at particular times, family size and family structure. These records also provide sibling names (1 inking brothers) and multiple marriage information (linking half brothers).

We used place information to provide a record of residence and internal migration and to provide an estimate of the length of time a household had been within the economy $(T)$. For analysis purposes, we consider only rural (R) and urban (U) residence where urban is defined as Salt Lake county. 
We have linked individuals through time and across records and we have linked these individual histories by family relationship. The core of the sample was created by linking census wealth records using name, location, age and birth place data. We then added a random sample of the households from each census year that did not appear in more than one of these censuses. We separately coded links that were "certain" from those for which there were some discrepancies in name spellings or age estimates between census years, "uncertains". We were, however, conservative in our efforts and subsequent analysis has shown no statistically significant differences between "certains" and "uncertains" and hence we no longer carry the coding distinguishing the two. To this core of linked and randomly sampled individuals, we added as many LDS financial records as we could, 1 inked by name across the records and through the years from 1855 to 1900 . We then reversed the procedure: first linking households in the Church financial records and then adding as much census information as was possible.

We added to this sample, now linked through time and between census and church financial records, records from either the censuses or financial records that were potentially fathers and sons. We verified these father-son 1 inks using the family vital statistic records from the Genealogical Library. We then searched the family vital statistic records for those in the core sample creating pointers linking those within the sample who were either fathers and sons or brothers. In addition, we added any records from the population data for those we could identify as sons or brothers of those in the sample by using the family vital statistic information.

Not all family links between brothers occur with a link to a father. Since we searched the family vital statistic records for those in our sample, we 
would often find brothers without finding fathers, who might have been dead or who might not have migrated to Utah with their sons. This particular aspect of the sample means that the sibling connections cover the full age range in each year of the sample and are not restricted to be young in the early years. We also found a number of new households that were formed over the fifty year period where we observed the father for a some years and then observed the father and son. Because of the extended period over which we sampled we also observe fathers and sometimes sons who die and a small group of three generation 1 inks.

We added to this linked data additional wealth data from the tax assessments and probates as well as occupational data from the 1880 and 1900 censuses. For these records we have neither population data nor random samples from population data. Rather we sought out only those records for individuals al ready in our sample. Otherwise, however, we have population data for wealth from 1850 to 1870 and income from 1855 to 1900 .

When we added data, anomolies would appear. At each point we purged from the data those links that became questionable with the new information. Obvious checks included: records past death or for an individual who was "too old"; records prior to birth or for an individual who was "too young"; the same name on multiple records from the same source in the same year; substantial age inconsistencies.

We believe that we have been fairly conservative at each point but we should note that all linking is by names with the attendant problems of mispelling and same names for different individuals. We tried to avoid both problems by not selecting or subsequently eliminating those with common names where the probability was high that there would be several individuals with the 
same name (e.g. John Jones, James Green). We have differentially coded "certain" family links from those that were "less certain".

The completed data set is essentially a panel, although an individual need not appear in each year either because the individual migrated in or formed a household later in the period; because the individual migrated out or died during the period; or because we could not make a link in a particular year. It is a panel with the unique characteristic that it is drawn from a fifty year history of an economy and that it has immediate family innks. Tabies 2 and 3 provide means and variances by year for fathers, sons and brothers.

\section{FAMILY EFFECTS AND INDIVIDUAL INCOME}

We test for unobserved family background effects by first estimating several variations of the now standard human capital specification for individual income,

(1) $\ln \left(y_{i j}\right)=x_{i j} B+e_{i j}$ where $i$ indexes sibs and $j$ indexes families and

(2) $e_{i j}=u_{j}+w_{i j}$.

$u_{j}$ is the family component of the variance. For some specifications, we pool the data over all or part of the 50 year period and in these instances impose a fixed effects model on the aggregate yearly effects. The complete set of regressions that serve as a basis for our analysis is found in the appendix. The general properties of the regression results can be seen in the following pooled regression for brothers taken from Table Al in the appendix: 


$$
\begin{aligned}
& \ln (y)=4.50+.062 \mathrm{~A}-.00068 \mathrm{~A}^{2}+.009 \mathrm{~T}-.23 \mathrm{R}+.043 \mathrm{FB} \\
& (.121)(.005)(.00006)(.002)(.029)(.025) \\
& +.56 \mathrm{~W}-.06 \mathrm{C}+.02 \mathrm{~S}-.19 \mathrm{~L}+.58 \mathrm{D} 55+.57 \mathrm{D} 57+.47 \mathrm{D} 59 \\
& (.039)(.037)(.06)(.04)(.08)(.05)(.06) \\
& +.55 \mathrm{D} 61+.48 \mathrm{D} 66+.27 \mathrm{D} 70+.28 \mathrm{D} 75+.24 \mathrm{D} 80+.27085 \\
& (.04)(.05)(.05) \quad(.05)(.05) \quad(.04) \\
& +.16 \mathrm{D} 90+.002 \mathrm{D})(.05) \\
& (.04) \quad(.05)
\end{aligned}
$$

$\mathrm{R}^{2}=.11$

\#OBS $=5580$

The regressions are normalized on farmers living in Salt Lake County in 1900 who are U.S. born. Elsewhere we have discussed the properties of these regressions at length, focusing on the effects of time within the economy (T), 1 ife cycle patterns ( $A$ and $A^{2}$ ) and changes in residence (R) and occupation $(W, C, S, L, F)$ in separate papers. (Kearl, Pope and Wimmer, 1980; Kearl and Pope, 1983a; Kearl and Pope, 1983b.) We note here that virtually all of the individual characteristics that we measure have the expected statistically significant effects on $\ln (y)$ but that like comparable analysis on modern data these individual characteristics do not explain a large percentage of the variance in log income.

Briefly, we find a pronounced concave life cycle in income with the peak occurring around age 45. Time within the economy ( $T$ ) has a positive effect on a household's income while those living in the rural areas (R) have lower incomes, ceteris paribus. Whitecollar workers (W) have higher incomes than do farmers while craft (C) and service (S) workers have incomes that are not significantly different from those of farmers. Laborers (L) have incomes substantially lower than farmers and those in other occupational categories. We find that foreign born have incomes a bit higher than comparable US born households. Finally, the pattern of year effects for income essentially accounts 
for price changes and growth and parallels the price decline over the 50 year period in the rest of the United States. While the relative magnitudes and significance of the coefficients change somewhat with specification and sample, the patterns are essentially the same for all the regressions reported in the appendix.

We used these estimates to sweep from individual incomes the effects of measured individual characteristics. Rather than estimating the variance component directly, we then estimated the intraciass correlation for related pairs using the resulting residuals. The residuals were stacked so that a member of the related pair appears as both a dependent and independent variable in a simple regression of residuals on residuals. This is equivalent to randomly ordering the observations. The resulting coefficient (the intercept should be zero since it is the expected value of the residuals) is an estimate of the intraclass correlation coefficient. A nonzero coefficient indicates that a common omitted effect links the paired observations that does not link observations of individuals who are not related. It therefore provides evidence that there is a "family" effect on individual income that is shared by the related individuals.

We find a significant unobserved family background effect for brothers, Table 4. Sharing a common family background explains around 20 percent of the variance in the logarithm of income. Brothers incomes are simply unlike those of randomly selected unrelated paris of individuals even when we account for similarities between brothers that are observable, including age, nativity and occupational choices. Part of the correlation between the economic position of brothers could be explained by the correlation in the ages (compare specifications 1 and 2, Table 4) reflecting "closer" positions on the income life 
cycle than those shared by randomly paired unrelated individuals. In fact, this effect is unimportant.

While age, residence and birthplace correlations between brothers affect the intraclass correlation estimate very little (compare specifications 1 or 2 with 3), it is clear that part of the influence of family is reflected in occupational choices that brothers make. The intraclass correlation falls about 10 precent when the effect of occupational choice is swept out, implying that brothers' occupational choices are correlated. This is, of course, consistent with the considerable contemporary evidence on unobserved family effects and occupational choices.

The size of the estimated family background effect for brothers' incomes is at the midpoint of the Jencks' range. The importance of the unobserved family background variable(s) relative to that of the observable individual characteristics is also consistent with modern data. Hence, in terms of the size of the estimated famiiy background effect, the importance of this effect relative to observed individual characteristics and the partial transmission of the family effect through occupational choices made by siblings, our data reveal similar patterns to those in modern data even though our sample was created differently and drawn from a dissimilar economy--one that is poor, agrarian with little emphasis on formal education. Differences among families appear to be an important and robust determinant of the variance in the distribution of income among individuals.

In the following sections we consider evidence from our data about the nature of the unobserved family background effect that is not available in contemporary data. We first consider the effect for wealth holdings for essentially the same households for which we have estimated the family effect on 
income. Using both income and wealth as indicators of socioeconomic position, we then consider differences between full and half brothers. This is followed by a section where we use a subsample of the data to explore family effects for brothers and half brothers when we observe the socioeconomic position of their father. Using a different subsample with multiple observations for each sib, we then differentiate between unobserved family and unobserved individual effects.

IV FAMILY EFFECTS AND WEALTH HOLDINGS

We begin with an econometric specification for the logarithm of wealth holdings comparable to specification (1) for log income:

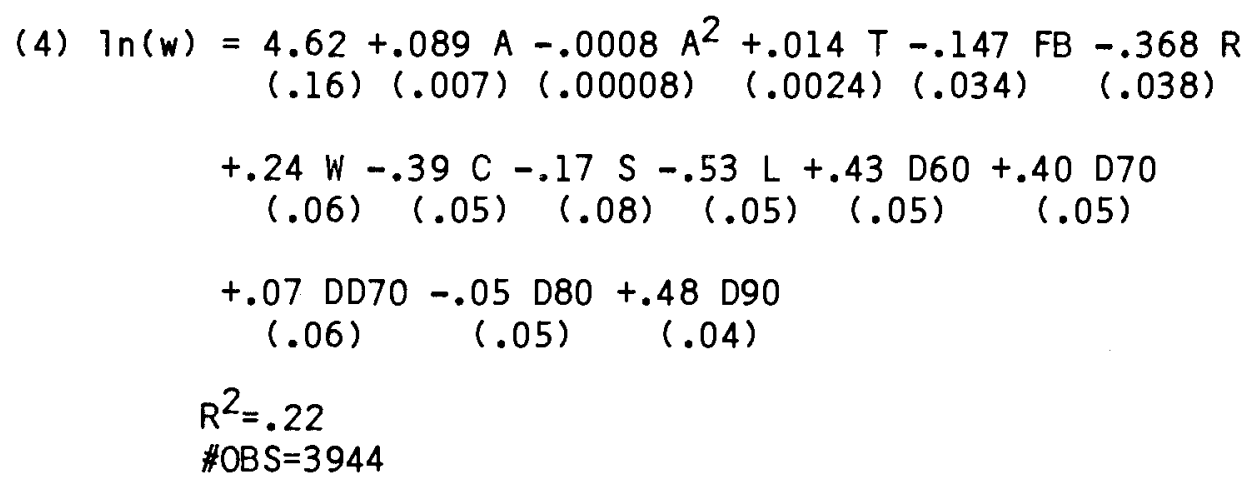

Again, the full set of equations used in the estimation of the intraclass correlation coefficient is found in the appendix. While the relative magnitudes change somewhat with specification and sample, specification (4) provides a general qualitative summary of the results for the wealth specifications and the relationship between the estimates for wealth and those for income. 
There is a pronounced concave lifecycle pattern to wealth holdings in our sample with a peak at age 58 (the comparable age-income peak is at age 45 ). Duration within the economy $(T)$ substantially increases wealth holdings and those who are foreign born or living in the rural area have weal th positions substantialiy below US born or those residing in the urban area. For income we also found a large positive effect for duration and a substantial negative effect for rural residence. However the effect of foreign birth was positive for income while it is negative for wealth. White collar workers have wealth holdings substantially above those for farmers, an effect also seen in income. However, while service and craft workers have incomes that are not significantly different from those of farmers, they have wealth holdings that are significantly lower than those of farmers. Common laborers have substantially lower weal th holdings and incomes than farmers.

The pattern of year dummies for wealth is more difficult to interpret since we essentialiy use them to splice the wealth series in 1870 . Hence they reflect both economic growth and changes in the measured variable between census and tax assessment records.

Table 5 provides estimates for the intraclass correlation coefficient using the logarithm of wealth as an indicator of soctoeconomic position and when the effects of the observed individual characteristics have been swept from $\ln (W)$. We find that unobserved family background explains about 30 percent of the variance in the $\log$ of wealth compared to 20 percent of the variance in the log of income.

The larger intraclass correlation for wealth is consistent with what would be expected if individual consumption behavior were determined by permanent rather than observed income. Transitory elements should be a relatively larger 
component of income than of wealth and hence more of the variance in income should be truly stochastic. If individual consumption were determined by permanent income, savings would fluctuate with transitory income as would wealth holdings but the differences in the means between wealth and income would imply that these fluctuations contributed relatively less to the variance of wealth. Put differently, differences in family backgrounds are relatively more important in determining the variance in a more permanent measure of economic position, wealth, than they are in explaining a measure with a larger transitory component, income. This suggests that family differences tend to be associated more closely with permanent differences rather than transitory differences in the distribution of economic outcomes.

In addition, however, if parents make efficient investment decisions relative to the human capital accumulation of their children, thereby differentially investing in siblings in response to differing individual abilities, but want to be egalitarian within the family, they would compensate those with lesser ability by engaging in differential intra vivos wealth transfers or provide compensatory bequests. This compensatory behavior would imply a larger family background effect on weal th than on income. Indeed, if there were no important constraints on parental ability to differentially invest according to sib ability, the intraclass correlation for earnings would be nonzero only if sibling ability had an unobserved common family component. However, the transitory elements noted earlier, the likely constraints on parental compensatory behavior as well as income from capital, do not allow us to interpret the intraclass correlation for income as measuring only the unobserved family element of individual ability (See Behrman, Pollack and Taubman or Sheshinski and Weiss). We note that recent attempts to test for efficient human capital 
intergenerational transfers suggest that bequests do not appear to compensate for differences in ability (Menchik; Tomes).

For both income and wealth, we used a Chow test for differences in the intraclass correlation by wealth and household size. In neither case did we find significant evidence which would indicate that, for example, the intraclass correlation was higher for brothers with wealthy fathers than for brothers with poor fathers or that family background effects differed systematically and substantially between "large" families and "small" families. The latter is a little surprising since, while common backgrounds differ among families, it would seem that the differences might be correlated with family size. When we examine these results in a slightly different way below we do find some family size effect. We also considered systematic variation in the intraclass correlation with birth order but also failed to find evidence that birth order systematically affected the intraclass correlation. In this area, however, our data present some problems since we have a large number of half brothers which make sib ordering problematic.

These results are based on data pooled from the full fifty year period covered by our sample. It is possible that the estimates change with time as, for example, the economy matures, or that our results reflect a compositional effect. We have estimated comparable intraclass correlations using only cross sections of sib pairs and, while the estimates vary somewhat, there are no systematic patterns different from those of the pooled data set. Another area of concern about reported intraclass correlations is the possiblity of correlation between observed characteristics and errors such that $E\left(U_{i} \mid X_{i j}\right)$ $\neq 0$ so that a random effects specification would involve mismeasurement. Hausman (1978) proposed a specification test which we have applied to some 
of our equations. While the overall $x^{2}$ test based on the decrease in residual sums of squares with augmented transformed variables ( $p$. 1269, Hausman, 1978) is failed with a random effects specification; the problems seem to be centered on the age variables and the life cycle. Further work will be needed to gauge the importance of the relationship between $U_{j}$ and some of the $x_{j}$.

Perhaps the most serious concern, at present, is the omission of education from the sweeping regressions. If formal education has a positive influence on income and wealth as expected, the lack of educational data reduces the variance explained by the regression and increases the measured common background effect if the education of siblings is correlated. The mismeasurement of the intraclass correlation in the sweeping regressions such as occupation, nativity and place of residence proxy for part of the effect of education. While virtually all of the Utah population was classified as literate on the census manuscript, formal education was relatively limited in the nineteenth century Utah. Nevertheless, further work is needed to bound the effect of omission of education from the sweeping regressions on the measurement of the family background effect.

\section{$\checkmark$ HALF VERSUS FULL BROTHERS}

We can separate the contribution of the father to the unobserved family effect from that of being raised in a common home by considering the differences between full brothers raised in the same home and half brothers who share a common father but who, in our sample, would not have been raised in a common home. Table 6 provides estimates when the sample is split this way.

Half brothers, on average, share fewer genes than do full brothers. (Expected excess homozygosity would be $50 \%$ for full brothers and $25 \%$ for half brothers.) 
They also, in our sample, do not share a common home since polygynous families were usually maintained in separate houses or living areas for each wife. Therefore, half and full brothers would only have similar intraclass correlations if the dominant component of the family background effect was the contribution of the father to his children. That is, if the intraclass correlations for brothers do not differ from those for half brothers, the unobserved family effects must be primarily non-genetic and primarily attributable to the father's role in creating a common environment for his sons. Conversely, if half brothers are no more similar than randomly selected unrelated individuals, then neither genetics nor the father's role matter and the common family effect would be attributed solely to the environment shared within a common home. However, if there are unobserved family background effects for both half and full brothers, the source of the differences could be both genetic and environmental since brothers and half brothers differ on both dimensions in our sample.

We clearly do not find that half brothers raised in separate homes are like randomly selected unrelated individuals. Rather, we find significant unobserved family background effects for half brothers for both wealth holdings and for income. Sharing a common father explains about 26 percent of the variance in $\log$ wealth and about 19 percent of the variance in $l 0 g$ income (we continue to find that the common family effect is larger for log wealth than it is for $\log$ income by about 50 percent). Sharing both a common father and a common mother explains about 30 percent of the variance in log wealth and about 19 percent of the variance in log income. There is surprisingly little difference between full brothers and half brothers in this respect suggesting that in this economy, the father's contribution to the economic 
success of his children dominates other aspects of the unobserved family variable. The results cast some doubt on a simple genetic explanation.

We note that a relatively larger share of the family effect appears to be transmitted through correlated occupational choices for half brothers than for brothers. That is, when individual occupational choices are accounted for (specification 4), the intraclass correlation for half brothers, still significant and maintaining the spread between income and wealth, is relatively smaller than the comparable intraclass correlations for full brothers. That is, when we account for occupational choices, sharing a common father explains 15 percent of the variance in $\log$ income and 23 percent of the variance in log wealth. This compares with 29 percent and 18 percent, respectively, for those who share a common father and a common mother. It makes sense, of course, that an important element in the environment shared by half brothers is the occupational choice of their common father which may very well influence their occupational choices. However, there remains a substantial correlation in the economic position of those raised in separate homes even when we account for this element of their common environment.

\section{OBSERVED AND UNOBSERVED COMMON FAMILY BACKGROUNDS}

Brothers share attributes of their common father, including those that are observable such as father's age, occupation, income or wealth. We now consider the degree to which the common family background effect present in our data is adequately accounted for by the observed characteristics of the sibs' father. The observed socioeconomic position of the father might directly affect sibs because of the advantages or disadvantages the socioeconomic position 
allowed the father to confer on his children. Usually interest in this area centers on income or wealth transfers but there may be more general direct effects such as access, information or nepotism. Of course there may be indirect effects for which the observed socioeconomic position of the father proxies. These might include home environments if such environments differ systematically with father's socioeconomic status. Finally, to the degree that there are capital market imperfections that impede intergenerational human capital transfers, it would be expected that higher income or wealthier parents would be able to transfer "more" human capital to all sibs and, of course, having made efficient investment decisions be more capable of providing differential material wealth transfers.

Tables A.9 and A.10 provide a summary of regressions with $\log$ income and $\log$ wealth as dependent variables using the subsample of brothers for whom we observe the relevant data for their fathers. The parameter estimates for the individuals own characteristics do not differ much from the regressions we discussed earlier and the qualitative properties of the regressions do not change with the extended specification. To these own characteristics we have appended those noted in the table for the individual's father and family.

With the exception of white collar for wealth and white collar and craft for income, father's occupational choice does not directly affect a son's income or wealth. A son's income and wealth are also statistically unaffected by the father's age, time within the economy, birth place or place of residence. Each of these, as we noted earlfer, affect a person's own income or wealth position and hence each indirectly affects the son's position to the degree that there is a relationship between a father's income or wealth and his son's 
income or wealth. However, even when we account for the substantial effect of being a white collar worker on an individual's income or wealth, there is an additional substantial advantage conferred on the sons of white collar workers in this economy. This cannot be skill transmittal or else we would expect also to see significant positive effects from fathers who were craftsmen and perhaps significant negative effects from fathers who were unskilled, common 1aborers. We observe neither of these, rather there is no significant relationship between fathers who are unskilled and their son's income or wealth and the relationship between fathers who are craftsmen and their sons is negative for income but not significant for wealth.

A father's income positively affects his son's income as does a father's wealth his son's wealth. A ten percent increase in wealth would yield a 1.5 percent increase in a son's wealth. Put differentiy, a ten percent deviation between fathers' wealth would cause a 1.5 percent deviation between the wealth of sons. The corresponding elasticity for income is about.l. Both of these, while statistically significant, would indicate substantial regression toward the mean if there were no other avenues through which fathers affected sons. For household size, we find that a son in a larger family will have lower wealth, ceteris paribus. The sign is also negative for income but the coefficient is not significant. If the family resource allocational rule first allocated parental resources for human capital accumulation and then compensated with differentially allocated material wealth among sibs, family size would be expected to have negative effects on both income and weal th but a larger effect on wealth so long as families have different material resources.

We used these regressions to once again purge from the dependent variable the effects of those individual and family characteristics that were observable 
and then estimated the intraclass correlation for brothers as shown in Table 7. We continue to find a significant unobserved family effect, with unobserved family background explaining 10 percent of the variation in $10 g$ income and 19 percent of the variation in $\log$ wealth. These compare with 13 and 23 percent when the observable common background effects are not directly estimated but are treated as part of the unobservable. Hence, observable common background characteristics account for only a little over 20 percent of the family effect. The remaining family affect is not effectively proxied by the father's own socioeconomic position as measured by income, wealth or occupation. This finding is also consistent with much contemporary work (see Taubman, et al. for a survey) but most contemporary studies do not have the rich set of characteristics that we have for fathers and hence this finding strengthens somewhat those drawn from contemporary data. While, as noted above, these results are roughly consistent with an efficient investment-cum-compensatory transfer allocational rule, the substantial unobserved family background effect when observed parental income and weal th are accounted for, suggests that resources other than material wealth or income are important in intergenerational 1 inks.

We can look at the common family effect in a slightly different way by treating fathers and sons as we have brothers, purging the effects of ow $n$ characteristics and then considering the possibilities of correlated residuals when the individuals are paired by family relationship. Table 8 provides estimates of the intraclass correlation for $\log$ income and wealth of fathers and sons. It should be noted that the fathers were quite old at the time the income or wealth was observed contemporaneously with their son's income or wealth. 
The low intraclass correlation in specification 1 is to be expected given the pronounced 1 ife cycle pattern in both income and wealth holdings since the life cycle will explain a substantial amount of the variance for individuals whose ages are separated by a substantial number of years as would be true for fathers and sons. This result, in a sense, indirectly confirms the presence of an age-income or age-wealth profile. When the contribution of age to the economic position of an individual is accounted for, the intraclass correlations for income are very close to those estimated from brothers. For wealth holdings, however, we find about 20 percent of the variance is explained by the unobserved common background shared by fathers and sons. The unobserved background shared by brothers explains about 30 percent of the variance for brothers.

Considering fathers and sons rather than brothers indicates the ambiguity in the notion of "unobserved family background". For brothers, family background is that unobservable that is common to brothers; for fathers and sons, family background is that unobservable that is common to fathers and sons. Sons share one half of the genes of their father. Brothers may share from virtually 0 to 100 percent but on average would also share 50 percent of the genes of their common father. However, fathers and sons are not raised in the same homes and hence not in the same home environments. Conversely, brothers, who have a wider variance in shared genes, are raised in a common home by a common mother.

While we cannot estimate the relative contributions of genes and environment, we can jointly estimate the two family effects, father-son and brother-brother. We assume an error-components model where the error is partitioned into a brother-brother family component, a father-son family component and a stochastic component. By construction, the brother-brother component includes only those 
things common to brothers that are not common to fathers and sons while the father-son component includes only those things common to fathers and sons that are not common to brothers. We jointly estimate the components using a maximum likelihood extimator (LISREL). Table 9 summarizes the results.

The estimated brother-brother variance component is significantly above the estimated father-son variance component. For log wealth, that unobservable common to brothers alone explains about 20 to 23 percent of the variance while that unobservable common to fathers and sons explains about 8 to 10 percent of the variance. For log income, the percentages are about 10 percent and 15 percent respectively.

\section{INDIVIDUAL VERSUS FAMILY EFFECTS}

The panel nature of our data allow us to consider unobserved individual effects as well as unobserved family effects since we can use observations on the same individual at different points in time. Unobserved individual effects would include those aspects of individual ability that do not change with time and which are not shared with a sibling. Those aspects of ability that might change with time are not considered in our analysis. Some, however, will be captured by the changes in observed individual characteristics such as occupation that occur with time. We estimate, then, a variance or error components model using paired brothers with paired observations on each individual (since we have more than pairs of observations on each individual, our data allow for potentially richer and more complex specifications than that estimated here. We intend to pursue such models later.) We assume that the error is generated by a process that includes a family effect, an individual effect and a stochastic element, 
(5)

$$
e_{i j k}=u_{i}+v_{j}+w_{i j k}
$$

where $i$ indexes the family, $j$ indexes the individual and $k$ indexes time. While we use a maximum likelihood estimator (LISREL), loosely, the covariances between years for the same individual estimate the sum of an individual variance component and a family variance component while the covariances between sibs estimate the family component. The family variance component is, thus, directly estimated while that for the individual is easily recoverable. The observed error variances for individuals estimate the sum of the family, individual and stochastic components. Table 10 provides estimates for $10 \mathrm{~g}$ income and $\log$ wealth for brothers.

Adjusting for the differences in the variances of $\log$ income and $\log$ wealth we find that the percentage of the variance attributable to the unobserved family effect continues to be in the .22-.28 range for wealth and the .15-.19 range for income. The interesting aspect of this model of the covariance structure for brothers is the relative importance of individual effects for wealth and income. For wealth, we find that the unobserved individual variance component is about one half that of the unobserved family variance component. For income, however, the unobserved individual effect dominates, being over twice that for the family effect. Moreover, while observable characteristics explain over 20 percent of the variance in wealth and about 10 percent of the variance in $10 \mathrm{~g}$ income, the total variance explained by observable and unobservable family and individual characteristics is about 50 percent of the variance of wealth but around 65 percent of the variance of income. Again, if ability differences are enhanced by efficient human capital transfers from parents to children but these transfers are then offset by 
wealth transfers that are compensatory, the pattern we observe of relatively larger individual effects and smaller family effects for income and relatively smaller individual effects and larger family effects for wealth would be produced. Nothing in this explanation would suggest, of course, that the combined effects would explain a large or small amount of the variance. It is simply the case for our data, that the explained variance from the regression analysis on observed characteristics alone gives a much distorted picture of the nature of the stochastic contribution to the distributions of income and wealth.

\section{CONCLUDING COMMENTS}

The variance in family backgrounds appears to be an important contributor to the dispersion of individual income and wealth. We conclude, based on the differences between the effect of unobserved family background on income and wealth, that these effects are more likely related to permanent differences than transitory differences in the distribution. While we find that part of this effect is reflected in occupational choices made by related individuals and another part is explained by the observed socioeconomic position of the father, most of the effect cannot be explained by either of these two avenues of intergenerational transmission.

We also find that unobserved individual differences are important contributors to the variance in socioeconomic positions. Observable individual characteristics, unobservable individual characteristics and unobservable family effects explain over one half of the variance in income and in wealth. This poses a problem for policy arguments that are based on stochastic elements dominating the distributions or on providing greater equality of opportunity within which individuals can make choices. Models of family allocational 
rules, ability, and socioeconomic rewards should accommodate two important empirical results. First, we found that while unobservable individual effects were important determinants of both income and wealth distributions, they are relatively more important determinants of the distribution of income. Second, while we also found that unobservable family effects were important determinants of both income and wealth distributions, they are relatively more important in determining the distribution of wealth.

We have suggested at various points, that much of what we observe seems to us to be consistent with an efficient investment-cum-compensatory transfer allocational rule but our efforts do not provide a direct test of an allocational model since none of our specifications are specifically constrained by such a rule. Thus, the relatively more important family effect for wealth could reflect either equal transfers within family where resources differed (including time) between families or else compensating transfers such that sibling wealth positions looked more alike than would be predicted from incomes.

We do suggest that permanent/transitory differences between wealth and income may explain the larger family effect on wealth. This cannot be a complete explanation, however, or we would expect that unobserved individual differences, also presumed to be more permanent, would also explain proportionally more of the distribution of wealth than the distribution of income. Since this is not the case, a more complex phenomenon is presumably generating the data we have collected and analyzed. 
TABLES 


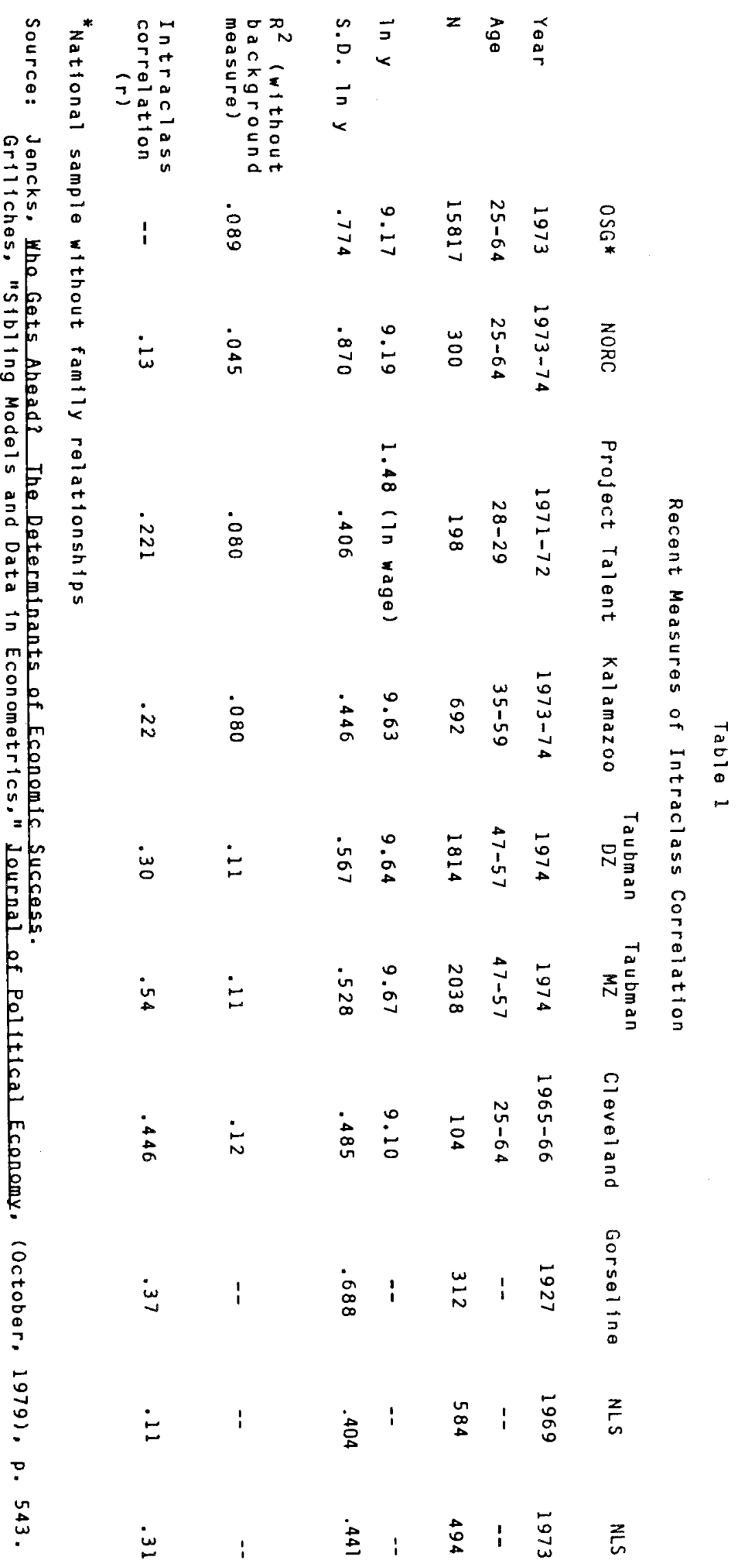




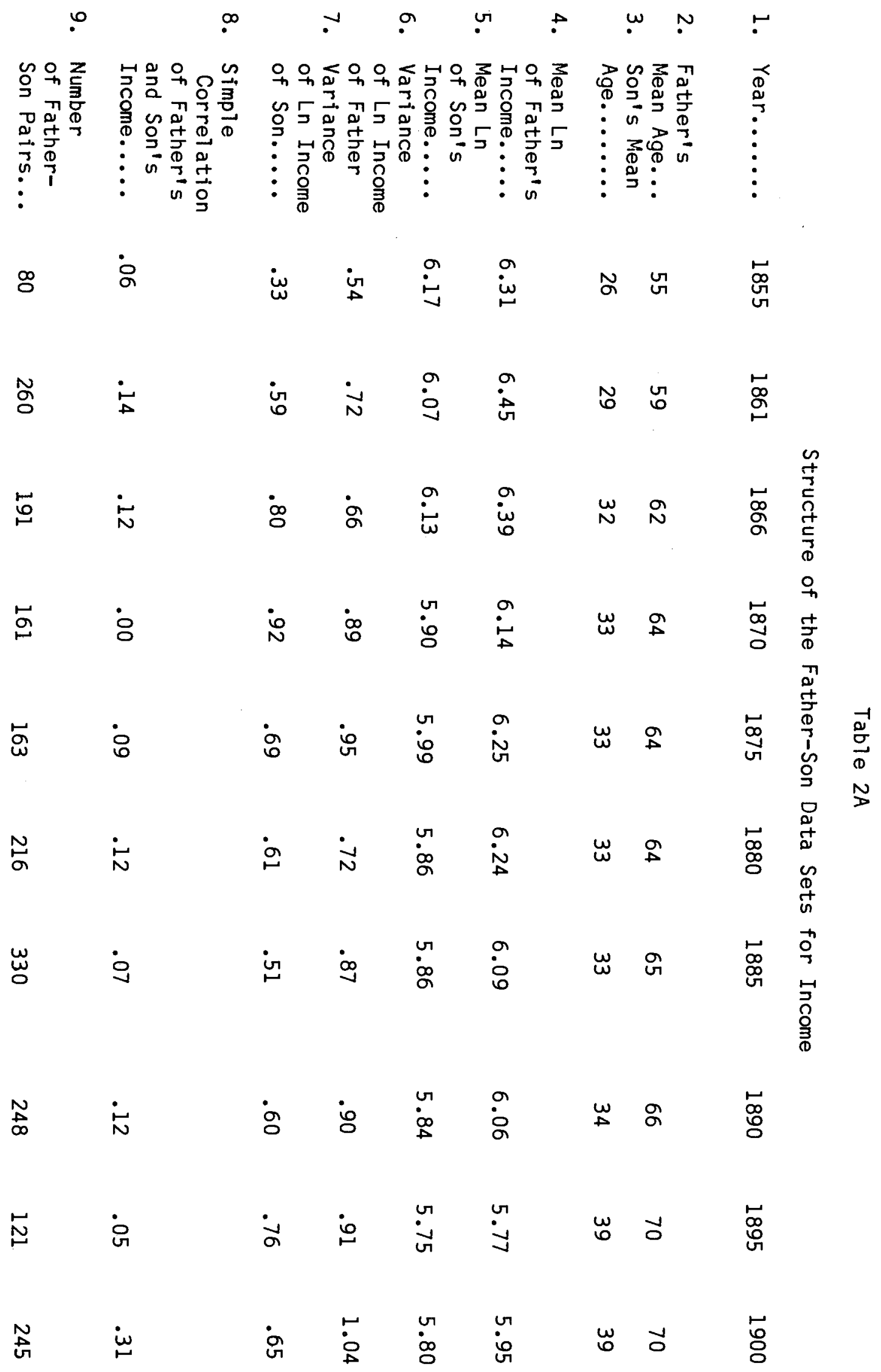


Table 2B

Structure of the Father-Son Data Sets for Wealth

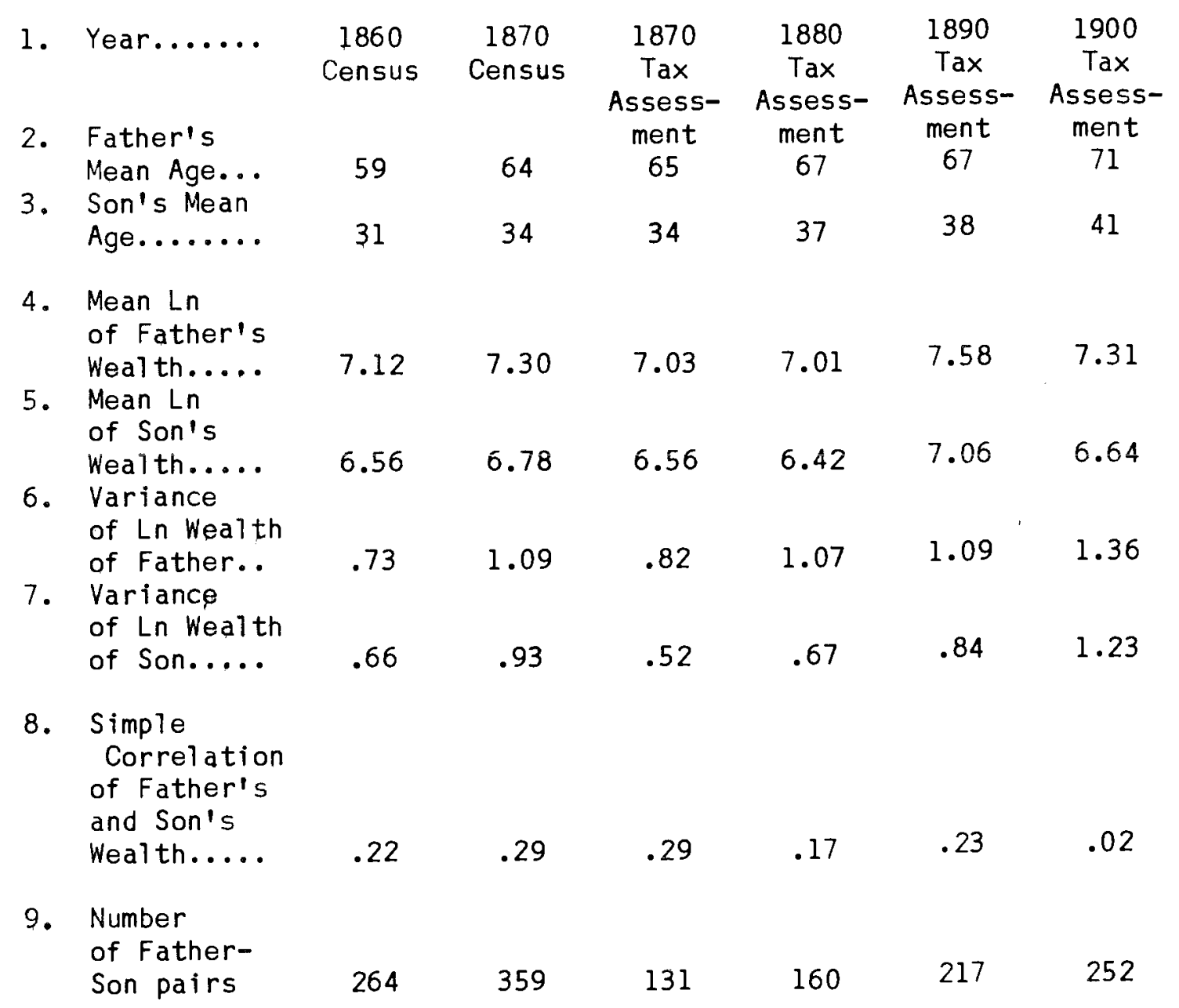




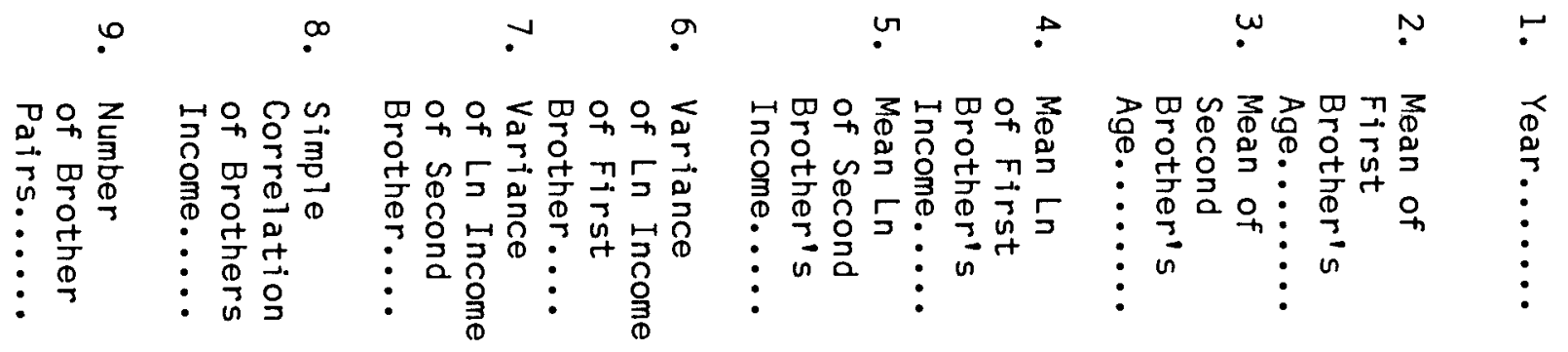

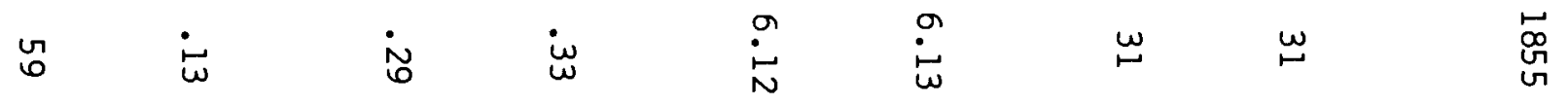

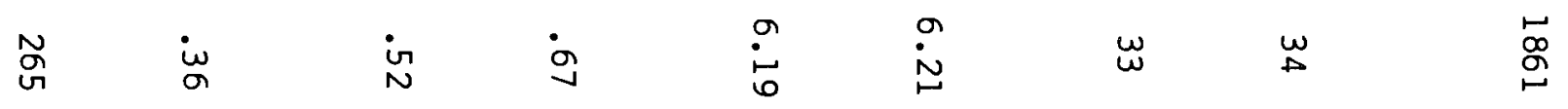

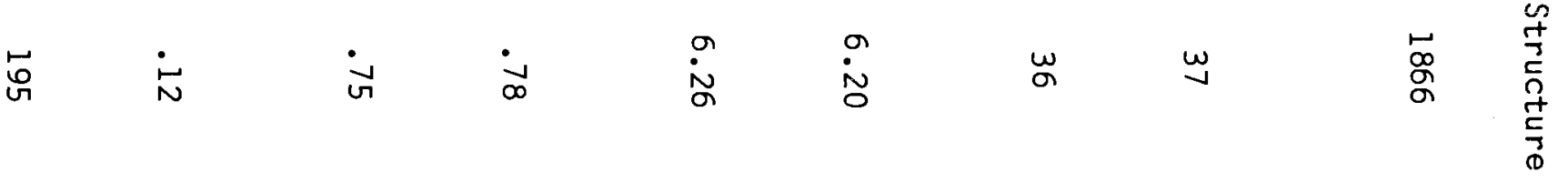

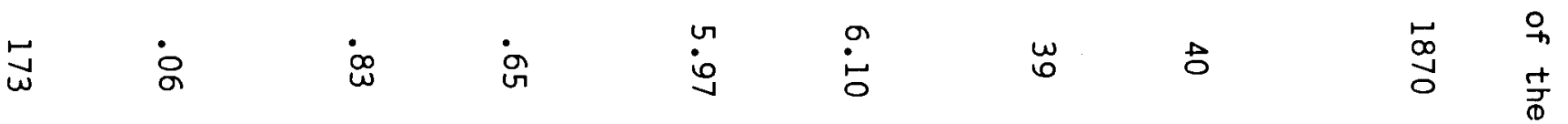

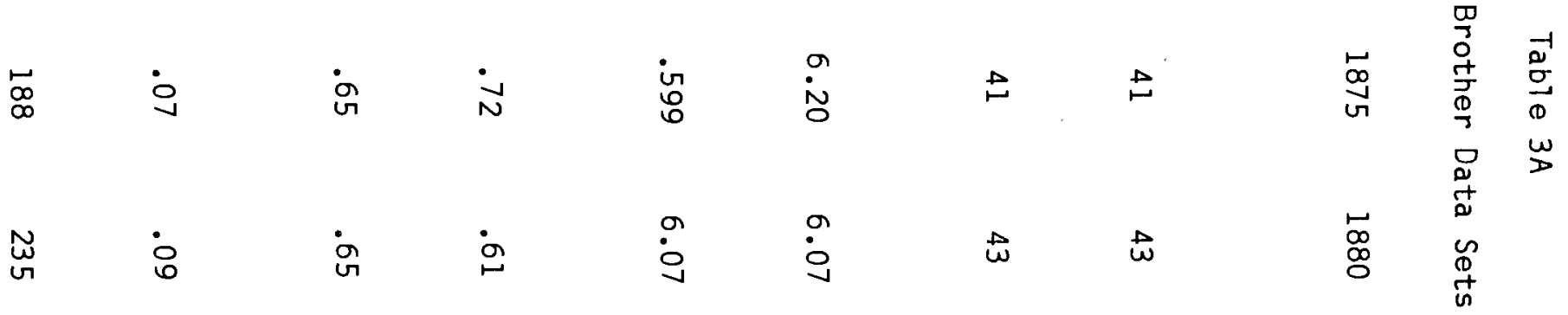

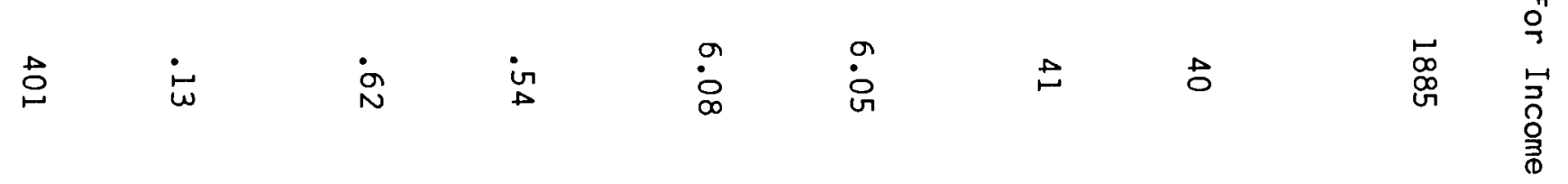

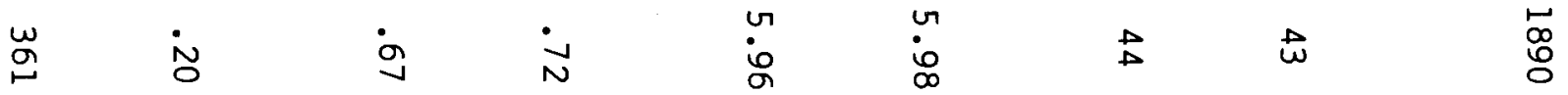

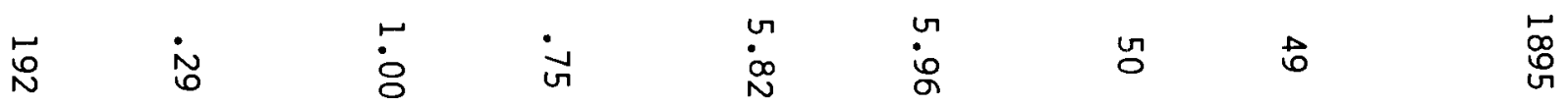

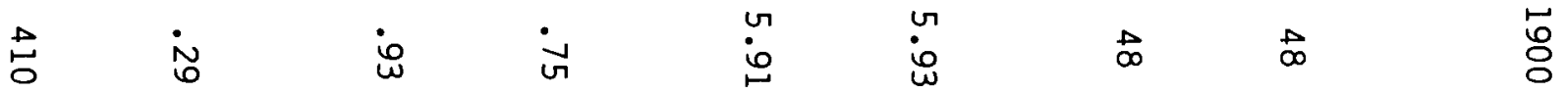


Table 3B

Structure of the Brother Data Sets for Wealth

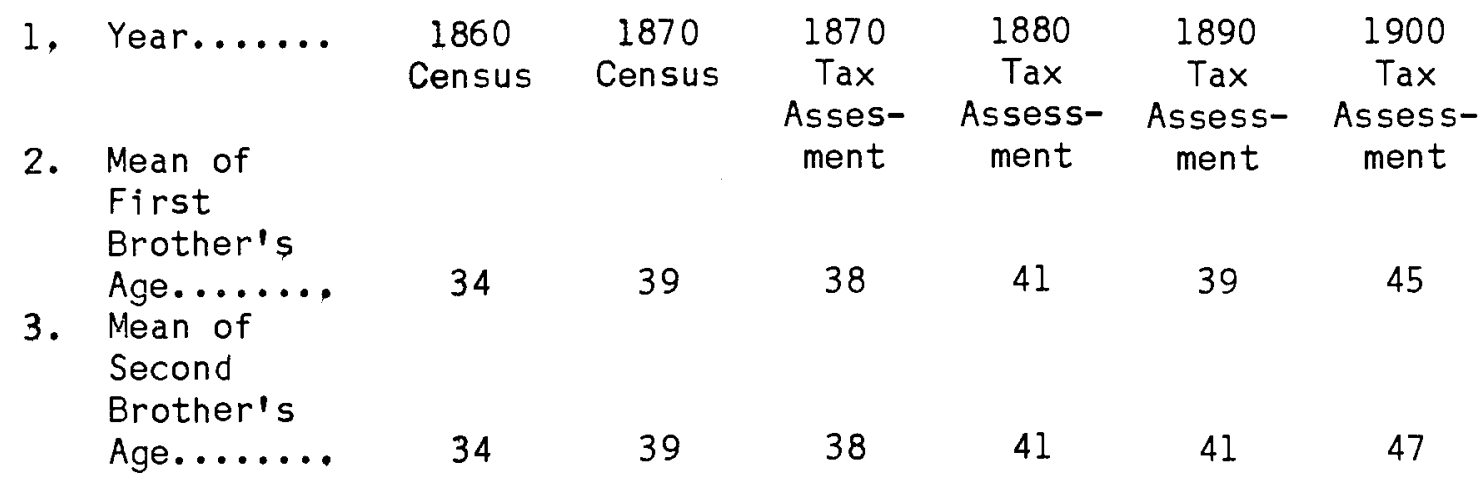

4. Mean Ln

of First

Brother's

Wealth.....

$\begin{array}{llllll}6.77 & 6.87 & 6.51 & 6.58 & 7.13 & 6.86\end{array}$

5. Mean Ln

of Second

Brother's

Wealth.....

$\begin{array}{llllll}6.80 & .699 & 6.64 & 6.59 & 7.13 & 6.95\end{array}$

6. Variance

of Ln Wealth

of First

Brother....

$.79 \quad .79$

.79

.59

.77

1.01

1.57

7. Variance

of Ln Wealth

of Second

Brother....

.95

.93

.56

.64

.86

1.44

8. Simple

Correlation

of Brothers

Wealth.....

.43

.43

.37

.34

.33

.20

9. Number

of Brother

Pairs......

169

246

443

435 


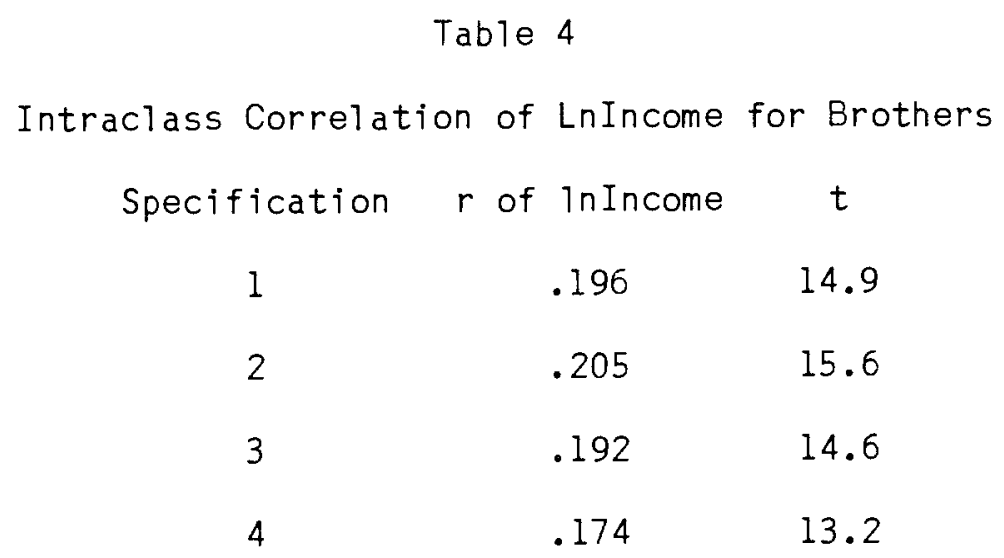

Specification 1: Sweeping Regression includes constant and year dummies.

Specification 2: Sweeping Regression includes constant, year dummies, age and age ${ }^{2}$.

Specification 3: Sweeping Regression includes constant, year dummies, age, age $^{2}, T, R$, and FB.

Specification 4: Sweeping Regression includes constant, year dummies, age, age $^{2}, T, R, F B, W, C, L$, and $S$.

See Table A.I for estimates. 
Table 5

Intraclass Correlation of LnWealth for Brothers

$\begin{array}{ccc}\text { Specification } & r \text { of LnWealth } & t \\ 1 & .314 & 20.7 \\ 2 & .303 & 20.0 \\ 3 & .295 & 19.4 \\ 4 & .278 & 18.2\end{array}$

Specification 1: Sweeping Regression includes constant and year dummies.

Specification 2: Sweeping Regression includes constant, year dummies, age and age ${ }^{2}$.

Specification 3; Sweeping Regression includes constant, year dummies, age, age $^{2}, T, R$, and $F B$.

Speciffication 4: Sweeping Regression includes constant, year dummies, age, $\operatorname{age}^{2}, T, R, F B, W, C, L$, and $S$.

See Table A.2 for estimates. 


\section{Table 6}

Comparison of Intraclass Correlations for

Full and $\mathrm{Half}$ Brothers

\begin{tabular}{|c|c|c|c|c|c|c|c|c|}
\hline \multirow[b]{3}{*}{ Specification } & \multicolumn{4}{|c|}{ Fuli Brothers } & \multicolumn{4}{|c|}{ Half Brothers } \\
\hline & \multicolumn{2}{|c|}{$\operatorname{Ln}(Y)$} & \multicolumn{2}{|c|}{$\operatorname{Ln}(W)$} & \multicolumn{2}{|c|}{$\operatorname{Ln}(Y)$} & \multicolumn{2}{|c|}{$\operatorname{Ln}(W)$} \\
\hline & r & $t$ & $r$ & $t$ & $r$ & $t$ & $r$ & $t$ \\
\hline 1 & .194 & $(13.1)$ & .350 & $(20.4)$ & .198 & $(7.0)$ & .212 & $(6.5)$ \\
\hline 2 & .201 & $(13.6)$ & .313 & $(18.2)$ & .205 & $(10.3)$ & .271 & $(8.4)$ \\
\hline 3 & .191 & $(12.9)$ & .302 & $(17.5)$ & .189 & $(6.7)$ & .260 & $(7.9)$ \\
\hline 4 & .178 & $(12.0)$ & .290 & $(16.7)$ & .146 & $(5.1)$ & .225 & $(6.9)$ \\
\hline
\end{tabular}

Specification l: Sweeping Regression includes constant and year dummies.

Specification 2: Sweeping Regression includes constant, year dummies, age and age ${ }^{2}$.

Specification 3: Sweeping Regression includes constant, year dummies, age, age $^{2}, T, R$, and $F B$.

Specifjcation 4: Sweeping Regression includes constant, year dummies, age, age $^{2}, T, R, F B, W, C, L$, and $S$.

See Tables A.3 and A.4 for estimates for full brothers and Tables A.5 and A. 6 for half brothers. 


\section{Table 7}

Intraclass Correlation of Brothers with Measured Common Family Attributes

\begin{tabular}{|c|c|c|c|c|c|c|}
\hline Specification & $r$ of & lnWeal th & $t$ & $r$ of & InIncome & $t$ \\
\hline 1 & & .307 & $(20.1)$ & & .12 & $(5.0)$ \\
\hline 2 & & .272 & $(20.4)$ & & .16 & $(6.7)$ \\
\hline 3 & & .255 & $(9.7)$ & & .14 & $(6.0)$ \\
\hline 4 & & .223 & $(8.7)$ & & .13 & $(5.8)$ \\
\hline 5 & & .208 & $(7.8)$ & & .11 & $(4.7)$ \\
\hline 6 & & .188 & $(7.0)$ & & .10 & $(4.2)$ \\
\hline
\end{tabular}

See Table 4 and Tables A.9 and A.10.

For specification 5 we add, for each brother, the father's characteristics except wealth to the sweeping regression.

For specification 6 we add, for each brother, the father's characteristics and father's wealth or income to the sweeping regression. 
Table 8

Intraclass Correlations of Fathers and Sons

\begin{tabular}{lccccc} 
& \multicolumn{2}{c}{ Income } & \multicolumn{2}{c}{ Wealth } \\
& $r$ & $t$ & $r$ & $t$ \\
Specification 1 & .09 & 5.92 & .10 & 5.15 \\
Specification 2 & .18 & 12.57 & .22 & 11.69 \\
Specification 3 & .17 & 11.98 & .20 & 10.96 \\
Specification 4 & .15 & 10.48 & .18 & 9.70
\end{tabular}

Specification 1: Sweeping Regression includes constant and year dummies.

Specification 2: Sweeping Regression includes constant, year dummies, age and age ${ }^{2}$.

Specification 3: Sweeping Regression includes constant, year dummies, age, age $^{2}, T, R$, and FB.

Specification 4: Sweeping Regression includes constant, year dummies, age, age $^{2}, T, R, F B, W, C, L$, and $S$.

See Table A. 7 and A. 8 for estimates. 
Table 9

Different Aspects of Common Family Background

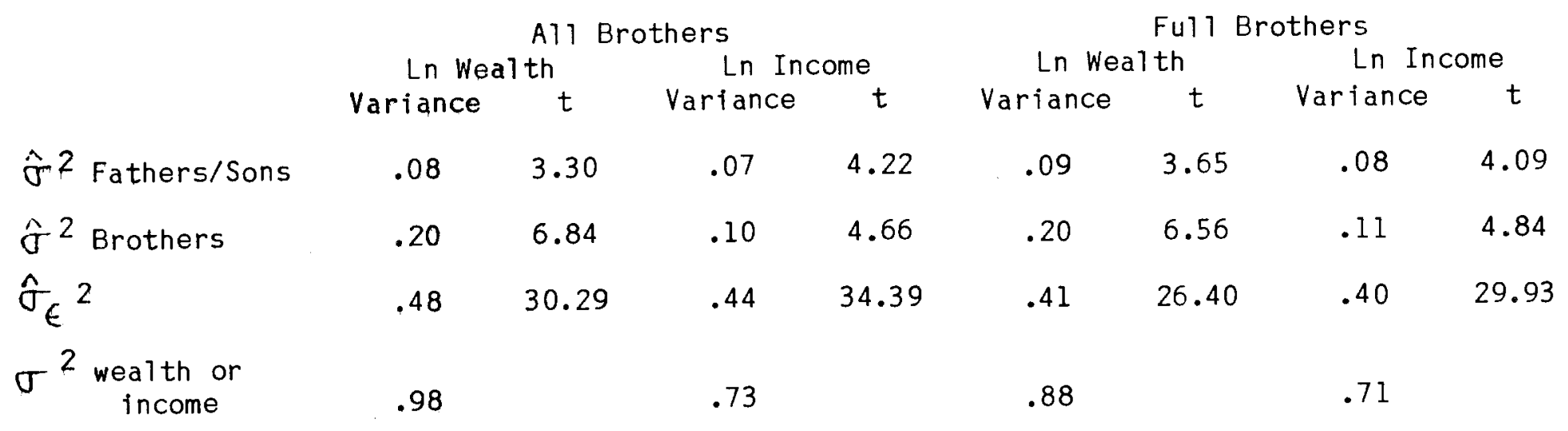


Table 10

Measurement of Individual and Family Effects for Brothers

$\begin{array}{lcccc} & \sigma^{2} & \begin{array}{c}\text { Ln Income } \\ \% \text { of total } \\ \text { variance }\end{array} & \sigma^{2} & \begin{array}{c}\text { Ln Wealth } \\ \% \text { of total } \\ \text { variance }\end{array} \\ \begin{array}{l}\text { Mean Total Variance......... } \\ \begin{array}{l}\text { Estimated Variance } \\ \text { Accounted for by: }\end{array}\end{array} & .68 & 100 & .95 & 100 \\ \begin{array}{l}\text { Observed Characteristitcs } \\ \text { (Occupation, age, etc)..... }\end{array} & .09 & 13 & .17 & 18 \\ \text { Unobserved Individual Effect } & .22 & 32 & .08 & 8 \\ \text { Unobserved Family Efect..... } & .11 & 16 & .18 & 19\end{array}$




\section{BIBL IOGRAPHY}

Balestra, Pietro and Marc Nerlove, "Pooling Cross Section and Time Series Data in the Estimation of A Dynamic Model: The Demand for Natural Gas," Econometrica, 34(3), (Ju1y 1966), pp 585-610

Becker, Gary A. and Nigel Tomes, "An Equilibrium Theory of the Distribution of Income and Intergenerational Mobility," The Journal of Political Economy, $87(6)$, (Dec 1979) PP 1153-1189

Behrman, Jere R., Robert A. Pollak and Paul Taubman, "Parental Preferences and Provision for Progeny," The Journal of Pol itical Economy, 90(1), (Jan 1982), pP 52-73

Behrman, Jere R., Z. Hrubec, Paul Taubman and T. J. Wales, Socioeconomic Success: A Study of the Effects of Genetic Endowments, Family Environment and Schooling, New York: North-Hol land, 1980

Behrman, Jere, Paul Taubman and Terrance Wales, "Controlling for and Measuring the Effects of Genetics and Family Environment in Equations for Schooling and Labor Market Success," from Kinometrics: Determinants of Socioeconomic Success Within and Between Families, Paul Taubman, ed., New York: North Hol 1and, 1977, pp 35-96

Behrman, Jere and Paul Taubman, "Intergenerational Transmission of Income and Weal th," American Economic Review, 66, (May, 1976) pp 436-440

Blinder, Alan S., "A Model of Inherited Wealth," Quarterly Journal of Economics, 87, (Nov 1973), pp 608-626

Brittain, John A., The Inheritance of Economic Status, Washington, D.C.: The Brookings Institution, 1977

Chamberlain, Gary, "Education. Income and Ability Revisited," from Latent Variables in Socio-Economic Models, Dennis J. Aigner and Arthur S. Goldberger, eds., New York: North-Holland, 1977, pp 143-162

Chamberlain, Gary and Zvi Griliches, "Unobservables with a Variance Components Structure: Ability, Schooling and the Economic Success of Brothers," from Latent Variables in Socio-Economic Models, Dennis J. Aigner and Arthur S. Goldberger, eds., New York: North-Holland, 1977, pp 253-284

Chamberlain, Gary, "Omitted Variable Bias in Panel Data: Estimating the Returns to Schooling," Annales de l'INSEE, 30/31, (1978), pp 49-82

Chamberlain, Gary and Zvi Griliches, "Unobservables with a Variance Components Structure: Ability, Schooling and the Economic Success of Brothers," International Economic Review, 16, (June 1975), pp 422-449 
Chamberlain, Gary and Zvi Griliches, "More on Brothers," from Kinometrics: Determinants of Socioeconomic Success Within and Between Families, Paul Taubman, ed., New York: North-Holland, 1977, pp 97-124

Griliches, Zvi, "Errors in Variables and Other Unobservables," from Latent Variables in Socio-Economic Models, Dennis J. Aigner and Arthur S. Goldberger, eds., New York: North-Holland, 1977, pp 1-34

Griliches, Zvi and William M. Mason, "Education, Income and Ability from Structural Equation Models in the Social Sciences. Arthur S. Goldberger and Otis D. Duncan, eds., New York: Seminar Press, 1973, pp 285-316

Griliches, Zvi, "Sibling Models and Data in Economics: Beginnings of a Survey," The Journal of Political Economy, 87(5 pt 2), (Oct 1979) pp S37-S64

Griliches, Zvi, "Estimating the Returns to Schooling: Some Econometric Problems," Econometrica, 45, (1977), pp 1-22

Goldberger, Arthur S. "Structural Equation Models: An Overview," from Structural Equation Models in the Social Sciences, Arthur S. Goldberger and Otis D. Duncan, eds., New York: Seminar Press, 1973, pp 1-18

Goldberger, Arthur S., "Twin Methods: A Skeptical View," from Kinometrics: Determinants of Socioeconomic Success Within and Between Families, Paul Taubman, ed., New York: North-Holland, 1977, pp 299-322

Goldberger, Arthur S. "Unobservable Variables in Econometrics," pp 193-213 from Erontiers of Econometrics, ed. by P. Zarembka, New York: Academic Press, 1974.

Haggard, Ernest A., Intraclass Correlation and the Analysis of Variance, New York: Dryden Press, 1958

Hause, J., "The Covariance Structure of Earnings and the On-the-Job Training Hypothesis," Annals of Economic and Social Measurement, 6(4), (1977), Pp 335-365

Hausman, Jerry A., "Specification Tests in Econometrics," Econometrica, 46(6), (Nov 1978), pp 1251-1271

Hausman, Jerry A. and William E. Taylor, "Panel Data and Unobservable Individual Effects, Econometrica, 49(6), (Nov 1981) pp 1377-1398

Ishikawa, Tsuneo, "Family Structures and Family Values in the Theory of Income Distribution," The Journal of Political Economy, 83(5), (Oct 1975), PP 987-1008

Jencks, Christopher, whe Gets Ahead? The Determinants of Economic Success in America, New York: Basic Books, 1977

Joreskog, Karl G., and Dag Sorbom, LISREL: Users Guide, Version V, Chicago: International Educational Services, 1981 
Joreskog, Karl, "A General Method for Estimating a Liner Structural Equation System," from Structural Equation Models in the Social Sciences, Arthur S. Goldberger and Otis D. Duncan, eds., New York: Seminar Press, 1973, pp $85-112$

Kearl, J. R., Clayne L. Pope and Larry T. Wimmer, "Household Wealth in a Settlement Economy: Utah, 1850-1870," Journal of Economic History, 40(3), (September, 1980), pp. 477-496.

Kearl, J. R. and Clayne L. Pope, "Life Cycles in Income and Wealth," (Working Paper, May, 1983b).

Kearl, J. R. and Clayne L. Pope, "Economic Mobility in Utah from 1850 to 1900," (Working Paper, March, 1983a).

Leibowitz, Arleen, "Family Background and Economic Success: A Review of the Evidence," from Kinometrics: Determinants of Socioeconomic Success With in and Between Families, Paul Taubman, ed., New York: North-Holland, 1977, pp 9-34

Lillard, Lee A. and Yoram Weiss, "Components of Variation in Panel Earnings Data: American Scientists 1960-70," Econometrica, 47(2), (March 1979), PP $437-454$

Loury, Glenn C., "Intergenerational Transfers and the Distribution of Earnings," Econometrica, 49(3), (July 1981), pp 843-868

Maddala, G. S., "The Use of Variance Components Models in Pooling Cross Section and Time Series Data", Econometrica, 39(2), (March 1971), pp 341-358

Menchik, Paul L. "Primogeniture, Equal Sharing and the U. S. Distribution of Wealth," euarterly Journal of Economics, 94, (March 1980), pp 299-316

Mundlak Yair, "On the Pooling of Time Series and Cross Section Data" Econometrica, 46(1), (Jan 1978), pp 69-85

Nerlove, Marc, "A Note on Error Components Mode1s," Econometrica, 39, (1971), pp 383-396

01 neck, Michael R., "On the Use of Sibling Data to Estimate the Effects of Family Background, Cognitive Skills and Schooling: Results from the Kalamazoo Brothers Study," from Kinometrics: Determinants of Socieecenomic Success With in and Between Families, Paul Taubman, ed., New York: North-Holland, 1977, pp 125-162

Searle, S. R., Linear Models, New York: Wiley, 1970

Sewell, William H. and Robert M. Hauser, "On the Effects of Families and Family Structure on Achievement," from Kinometrics: Determinants of Socioeconomic Success With in and Between Families, Paul Taubman, ed., New York: NorthHol land, 1977, pp 255-284 
Sheshinski, Eytan and Yoram Weiss, "Inequality Within and Between Families," The Journal of Political Economy, 90(1), (Jan 1982), pp 105-127

Taubman, Paul, Sources of Inequality in Earnings, New York: North-Holland, 1975

Taubman, Pau1, "The Determinants of Earnings: Genetics, Family and Other Environments: A Study of While Male Twins," American Economic Review, (Dec 1976)

Tomes, Nigel, "The Family, Inheritance and the Intergenerational Transmission of Inequality," The Journal of Pol itical Economy, 89(5), (Oct 1981), pp 928-958

Wallace, T.D., and Ashiq Hussain, "The Use of Error Components Models in Combining Cross Section with Time Series Data," Econometrica, 37(1), (Jan 1969), pp 55-72 
APPENDIX 


\section{TABLE A. 1 \\ REGRESSIONS AND INTRA-CLASS CORRELATIONS FOR \\ INCOME OF BROTHERS}

EQUATION 1

$\begin{array}{lccccr}\text { VARIABLE } & \text { MEAN } & \begin{array}{c}\text { STANDARD } \\ \text { DEVIATION }\end{array} & \begin{array}{l}\text { ESTIMATED } \\ \text { COEFFICIENT }\end{array} & \begin{array}{l}\text { STANDARD } \\ \text { ERROR }\end{array} & \begin{array}{r}\text { T-RATIO } \\ \text { NAME }\end{array} \\ \text { LNINCOME } & 6.0546 & 0.82302 & & & \\ \text { DF }\end{array}$


TABLE A. 1 ( Cont'd)

\section{REGRESSIONS AND INTRA-CLASS CORRELATIONS FOR INCOME OF BROTHERS}

EQUATION 2

\begin{tabular}{|c|c|c|c|c|c|}
\hline $\begin{array}{l}\text { VAR IABLE } \\
\text { NAME }\end{array}$ & MEAN & $\begin{array}{l}\text { STANDARD } \\
\text { DEVIATION }\end{array}$ & $\begin{array}{l}\text { ESTIMATED } \\
\text { COEFFICIENT }\end{array}$ & $\begin{array}{l}\text { STANDARD } \\
\text { ERROR }\end{array}$ & $\begin{array}{l}\text { T-RATIO } \\
5568 \text { DF }\end{array}$ \\
\hline LNINCOME & 6.0546 & 0.82302 & & & \\
\hline D 55 & 0.02115 & 0.14389 & 0.40729 & 0.08081 & 5.0401 \\
\hline D 57 & 0.07169 & 0.25799 & 0.45265 & 0.05205 & 8.6970 \\
\hline D 59 & 0.03979 & 0.19547 & 0.39291 & 0.06275 & 6.2613 \\
\hline D 61 & 0.09498 & 0.29322 & 0.44133 & 0.04716 & 9.3585 \\
\hline D 66 & 0.06989 & 0.25499 & 0.39509 & 0.05074 & 7.7859 \\
\hline D7 0 & 0.06201 & 0.24119 & 0.16500 & 0.05225 & 3.1579 \\
\hline D 75 & 0.06738 & 0.25071 & 0.21766 & 0.05043 & 4.3159 \\
\hline D 80 & 0.08423 & 0.27776 & 0.19284 & 0.04670 & 4.1292 \\
\hline D 85 & 0.14373 & 0.35084 & 0.21051 & 0.04051 & 5.1966 \\
\hline D 90 & 0.12939 & 0.33566 & 0.10090 & 0.04123 & 2.4472 \\
\hline D 95 & 0.06882 & 0.25317 & -0.02234 & 0.04962 & -0.45015 \\
\hline D 00 & 0.14695 & 0.35409 & & & \\
\hline AGE & 40.552 & 12.233 & 0.06810 & 0.00525 & 12.960 \\
\hline AGE2 & 1794.1 & 1083.4 & -0.00067 & 0.00006 & -11.472 \\
\hline F B E & 0.24498 & 0.43012 & & & \\
\hline $\mathrm{T}$ & 14.965 & 11.680 & & & \\
\hline $\mathrm{R}$ & 0.82204 & 0.38251 & & & \\
\hline W & 0.08298 & 0.27587 & & & \\
\hline $\mathrm{C}$ & 0.09462 & 0.29272 & & & \\
\hline $\mathrm{S}$ & 0.03154 & 0.17479 & & & \\
\hline $\mathrm{L}$ & 0.08190 & 0.27424 & & & \\
\hline IN TERCEPT & & & 4.2930 & 0.11790 & 36.411 \\
\hline $\mathrm{R} 2$ & 0.0504 & & & & \\
\hline $\mathrm{N}$ & 5580 & & & & \\
\hline & & & $0.204 b 1$ & 0.01311 & 15.604 \\
\hline
\end{tabular}


TABLE A. 1 (Cont'd)

REGRESSIONS AND INTRA-CLASS CORRELATIONS FOR INCOME OF BROTHERS

\author{
EQUATION 3
}

\begin{tabular}{|c|c|c|c|c|c|}
\hline \multirow{2}{*}{$\begin{array}{l}\text { VAR IABLE } \\
\text { NAME }\end{array}$} & MEAN & STANDARD & EST IMATED & STANDARD & T-RATIO \\
\hline & & DEVIATION & COEFFICIENT & ERROR & $5568 \mathrm{DF}$ \\
\hline L N I NCOME & 6.0546 & 0.82302 & & & \\
\hline \multirow{2}{*}{$\begin{array}{l}\text { D } 55 \\
\text { D } 57\end{array}$} & 0.02115 & 0.14389 & 0.46352 & 0.08132 & 5.7002 \\
\hline & 0.07169 & 0.25799 & 0.46447 & 0.05311 & 8.7459 \\
\hline $\begin{array}{l}\text { D } 59 \\
\text { D } 61\end{array}$ & 0.03979 & 0.19547 & 0.38059 & 0.06358 & 5.9864 \\
\hline \multirow{2}{*}{$\begin{array}{l}\text { D } 61 \\
\text { D } 66\end{array}$} & 0.09498 & 0.29322 & 0.44987 & 0.04796 & 9.3796 \\
\hline & 0.06989 & 0.25499 & 0.40855 & 0.05090 & 8.0271 \\
\hline D 70 & 0.06201 & 0.24119 & 0.19781 & 0.05239 & 3.7757 \\
\hline $\begin{array}{l}\text { D } 75 \\
\text { D } 80\end{array}$ & 0.06738 & 0.25071 & 0.23600 & 0.05035 & 4.6869 \\
\hline \multirow{2}{*}{$\begin{array}{l}\text { D } 80 \\
\text { D } 85\end{array}$} & 0.08423 & 0.27776 & 0.19086 & 0.04697 & 4.0639 \\
\hline & 0.14373 & 0.35084 & 0.23631 & 0.04067 & 5.8106 \\
\hline D 90 & 0.12939 & 0.33566 & 0.13538 & 0.04111 & 3.2936 \\
\hline \multirow{2}{*}{$\begin{array}{l}\text { D } 95 \\
\text { D } 00\end{array}$} & 0.06882 & 0.25317 & -0.02125 & 0.04930 & -0.43104 \\
\hline & 0.14695 & 0.35409 & & & \\
\hline$A G E$ & 40.552 & 12.233 & 0.06261 & 0.00530 & 11.817 \\
\hline AGE2 & 1794.1 & 1083.4 & -0.00070 & 0.00006 & -11.881 \\
\hline \multirow{2}{*}{$\begin{array}{l}\mathrm{FBE} \\
\mathrm{T}\end{array}$} & 0.24498 & 0.43012 & 0.02583 & 0.02567 & 1.0062 \\
\hline & 14.965 & 11.680 & 0.00871 & 0.00190 & 4.5895 \\
\hline $\mathrm{R}$ & 0.82204 & 0.38251 & -0.26270 & 0.02875 & -9.1372 \\
\hline W & 0.08298 & 0.27587 & & & \\
\hline C & 0.09462 & 0.29272 & & & \\
\hline $\mathrm{S}$ & 0.03154 & 0.17479 & & & \\
\hline \multirow{2}{*}{\multicolumn{2}{|c|}{$\begin{array}{l}\text { L } \\
\text { INTERCEPT }\end{array}$}} & 0.27424 & & & \\
\hline & & & 4.6168 & 0.12122 & 38.088 \\
\hline $\mathrm{R} 2$ & 0.0673 & & & & \\
\hline N & 5580 & & & & $91160 ?$ \\
\hline & & & 0.19190 & 0.01314 & 14.003 \\
\hline
\end{tabular}




\author{
TABLE A. 1 (Cont'd) \\ REGRESSIONS AND INTRA-CLASS CORRELATIONS FOR \\ INCOME OF BROTHERS
}

\title{
EQUATION 4
}

\begin{tabular}{|c|c|c|c|c|c|}
\hline $\begin{array}{l}\text { VARIABLE } \\
\text { NAME }\end{array}$ & MEAN & $\begin{array}{l}\text { STANDARD } \\
\text { DEVIATION }\end{array}$ & $\begin{array}{l}\text { ESTIMATED } \\
\text { COEFEICIENT }\end{array}$ & $\begin{array}{l}\text { STANDARD } \\
\text { ERROR }\end{array}$ & $\begin{array}{l}\text { T-RATIO } \\
5568 \text { DF }\end{array}$ \\
\hline LNINCOME & 6.0546 & 0.82302 & & & \\
\hline D 55 & 0.02115 & 0.14389 & 0.57622 & 0.08006 & 7.1975 \\
\hline D 57 & 0.07169 & 0.25799 & 0.57465 & 0.05264 & 10.917 \\
\hline D 59 & 0.03979 & 0.19547 & 0.47046 & 0.06255 & 7.5219 \\
\hline D6 1 & 0.09498 & 0.29322 & 0.54801 & 0.04747 & 11.545 \\
\hline D 66 & 0.06989 & 0.25499 & 0.48118 & 0.05012 & 9.6001 \\
\hline D 70 & 0.06201 & 0.24119 & 0.26592 & 0.05155 & 5.1583 \\
\hline D 75 & 0.06738 & 0.25071 & 0.28322 & 0.04947 & 5.7247 \\
\hline D 80 & 0.08423 & 0.27776 & 0.23634 & 0.04617 & 5.1193 \\
\hline D 85 & 0.14373 & 0.35084 & 0.26772 & 0.03994 & 6.7031 \\
\hline D 90 & 0.12939 & 0.33566 & 0.16400 & 0.04034 & 4.0651 \\
\hline D 95 & 0.06882 & 0.25317 & 0.00236 & 0.04830 & 0.48840 \\
\hline D 00 & 0.14695 & 0.35409 & & & \\
\hline A GE & 40.552 & 12.233 & 0.06184 & 0.00521 & 11.875 \\
\hline A G E2 & 1794.1 & 1083.4 & -0.00068 & 0.00006 & -11.794 \\
\hline F B E & 0.24498 & 0.43012 & 0.04284 & 0.02519 & 1.7005 \\
\hline $\mathrm{T}$ & 14.965 & 11.680 & 0.00933 & 0.00186 & 5.0228 \\
\hline $\mathrm{R}$ & 0.82204 & 0.38251 & -0.23154 & 0.02878 & -8.0464 \\
\hline$W$ & 0.08298 & 0.27587 & 0.55720 & 0.03918 & 14.223 \\
\hline $\mathrm{C}$ & 0.09462 & 0.29272 & -0.05692 & 0.03668 & -1.5517 \\
\hline$S$ & 0.03154 & 0.17479 & 0.01913 & 0.06041 & 0.31660 \\
\hline $\begin{array}{l}\text { L } \\
\text { INTERCEP }\end{array}$ & 0.08190 & 0.2 .7424 & $\begin{array}{c}-0.18635 \\
4.5015\end{array}$ & $\begin{array}{l}0.03882 \\
0.12068\end{array}$ & $\begin{array}{l}-4.8009 \\
37.300\end{array}$ \\
\hline R2 & 0.1069 & & & & \\
\hline $\mathrm{N}$ & 5580 & & & & \\
\hline$r$ & & & 0.17415 & 0.01318 & 13.208 \\
\hline
\end{tabular}


TABLE A. 2

REGRESSIONS AND INTRA-CLASS CORRELATIONS FOR WEALTH OF BROTHERS

\section{EQUATION 1}

\begin{tabular}{|c|c|c|c|c|c|}
\hline $\begin{array}{l}\text { VARIABLE } \\
\text { NAME }\end{array}$ & MEAN & $\begin{array}{l}\text { STANDARD } \\
\text { DEVIATION }\end{array}$ & $\begin{array}{l}\text { ESTIMATED } \\
\text { COEFFICIENT }\end{array}$ & $\begin{array}{l}\text { STANDARD } \\
\text { ERROR }\end{array}$ & $\begin{array}{l}\text { T- RATIO } \\
3938 \text { DF }\end{array}$ \\
\hline L NWE AL TH & 6.8751 & 1.0050 & & & \\
\hline D 60 & 0.14199 & 0.34908 & -0.11358 & 0.05355 & $\begin{array}{r}-2.1212 \\
0.5374\end{array}$ \\
\hline D 70 & 0.20233 & 0.40179 & 0.02603 & 0.04844 & \\
\hline DD 70 & 0.08570 & 0.27996 & -0.32701 & 0.06335 & -5.1623 \\
\hline D 80 & 0.12475 & 0.33047 & -0.31603 & 0.05575 & -5.6687 \\
\hline D 90 & 0.22465 & 0.41740 & 0.22801 & 0.04717 & 4.8335 \\
\hline $\begin{array}{l}\text { DOO } \\
\text { AGE }\end{array}$ & $\begin{array}{l}0.22059 \\
40.182\end{array}$ & $\begin{aligned} 0.41470 \\
11.393\end{aligned}$ & & & \\
\hline $\mathrm{AGE} 2$ & 1744.4 & 1014.6 & & & \\
\hline F B E & 0.25685 & 0.43695 & & & \\
\hline $\mathrm{T}$ & 14.137 & 10.409 & & & \\
\hline $\mathrm{R}$ & 0.80857 & 0.39348 & & & \\
\hline $\mathrm{W}$ & 0.07201 & 0.25853 & & & \\
\hline $\mathrm{C}$ & 0.10066 & 0.30092 & & & \\
\hline L & 0.08316 & 0.27617 & & & \\
\hline S & 0.03043 & 0.17178 & & & \\
\hline \multicolumn{2}{|l|}{ INTERCEPT } & & 6.9021 & 0.03351 & 205.99 \\
\hline $\begin{array}{l}\mathrm{R} 2 \\
\mathrm{~N}\end{array}$ & $\begin{array}{r}0.0330 \\
3944\end{array}$ & & & & \\
\hline$r$ & & & 0.31378 & 0.01512 & 20.749 \\
\hline
\end{tabular}


TABLE A. 2 (Cont'd)

REGRESSIONS AND INTRA-CLASS CORRELATIONS FOR

WEALTH OF BROTHERS

EQUATION 2

$\begin{array}{lcccrr}\text { VARIABLE } & \text { MEAN } & \begin{array}{c}\text { STANDARD } \\ \text { DEVIATION }\end{array} & \begin{array}{l}\text { ESTIMATED } \\ \text { COEFFICIENT }\end{array} & \begin{array}{l}\text { STANDARD } \\ \text { ERROR }\end{array} & \begin{array}{r}\text { T-RATIO } \\ \text { NAME }\end{array} \\ \text { LNWEALTH } & 6.8751 & 1.0050 & & & \\ \text { DF }\end{array}$


TABLE A. 2 (Cont'd)

REGRESSIONS AND INTRA-CLASS CORRELATIONS FOR

WEALTH OF BROTHERS

EQUATION 3

\begin{tabular}{|c|c|c|c|c|c|}
\hline $\begin{array}{l}\text { VAR IABLE } \\
\text { NAME }\end{array}$ & MEAN & $\begin{array}{l}\text { STANDARD } \\
\text { DEVIATION }\end{array}$ & $\begin{array}{l}\text { EST IMATED } \\
\text { COEFFICIENT }\end{array}$ & $\begin{array}{l}\text { STANDARD } \\
\text { ERROR }\end{array}$ & $\begin{array}{l}\text { T-RATIO } \\
3938 \text { DF }\end{array}$ \\
\hline $\begin{array}{l}\text { LNWE AL TH } \\
\text { D } 60\end{array}$ & $\begin{array}{l}6.8751 \\
0.14199\end{array}$ & $\begin{array}{l}1.0050 \\
0.34908\end{array}$ & 0.33829 & 0.05402 & 6.2625 \\
\hline D 70 & 0.20233 & 0.40179 & 0.33247 & 0.04684 & 7.0977 \\
\hline DD 70 & 0.08570 & 0.27996 & 0.02104 & 0.06025 & 0.3592 \\
\hline D 80 & 0.12475 & 0.33047 & -0.09052 & 0.05226 & -1.7321 \\
\hline D 90 & 0.22465 & 0.41740 & 0.47381 & 0.04451 & 10.6450 \\
\hline D 00 & 0.22059 & 0.41470 & & & \\
\hline A G E & 40.182 & 11.393 & 0.09326 & 0.00733 & 12.7260 \\
\hline AGE2 & 1744.4 & 1014.6 & -0.00082 & 0.00008 & -10.1390 \\
\hline FBE & 0.25685 & 0.43695 & -0.17641 & 0.03425 & -5.1512 \\
\hline $\mathrm{T}$ & 14.137 & 10.409 & 0.01321 & 0.00240 & 5.5040 \\
\hline $\mathrm{R}$ & 0.80857 & 0.39348 & -0.34890 & 0.03776 & -9.2401 \\
\hline W & 0.07201 & 0.25853 & & & \\
\hline C & 0.10066 & 0.30092 & & & \\
\hline L & 0.08316 & 0.27617 & & & \\
\hline S & 0.03043 & 0.17178 & & & \\
\hline \multicolumn{2}{|l|}{ INTERCEPT } & & 4.4869 & 0.16507 & 27.182 \\
\hline R2 & 0.1798 & & & & \\
\hline $\begin{array}{l}\mathrm{N} \\
\mathrm{r}\end{array}$ & 3944 & & & & \\
\hline $\mathbf{r}$ & & & 0.29486 & 0.01522 & 19.374 \\
\hline
\end{tabular}


TABLEA. 2 (Cont'd)

REGRESSIONS AND INTRA-CLASS CORRELATIONS FOR

WEALTH OF BROTHERS

\section{EQUATION 4}

\begin{tabular}{|c|c|c|c|c|c|}
\hline \multirow{2}{*}{$\begin{array}{l}\text { VAR I ABLE } \\
\text { NAME }\end{array}$} & MEAN & STANDARD & EST IMATED & STANDARD & T-RATIO \\
\hline & & & & & 3938 DF \\
\hline L NWEALTH & 6.8751 & 1.0050 & & & \\
\hline D 60 & 0.14199 & 0.34908 & 0.42889 & 0.05345 & 8.0240 \\
\hline D 70 & 0.20233 & 0.40179 & 0.39568 & 0.04620 & 8.5655 \\
\hline D D 70 & 0.08570 & 0.27996 & 0.07721 & 0.05921 & 1.3040 \\
\hline D 80 & 0.12475 & 0.33047 & -0.04709 & 0.05140 & -0.9162 \\
\hline $\begin{array}{l}\text { D } 90 \\
D 00\end{array}$ & 0.22465 & 0.41740 & 0.47836 & 0.04364 & 10.9610 \\
\hline DOO & 0.22059 & 0.41470 & & & \\
\hline$A G E$ & 40.182 & 11.393 & 0.08865 & 0.00721 & 12.3010 \\
\hline AGE2 & 1744.4 & 1014.6 & -0.00077 & 0.00008 & -9.7207 \\
\hline F B E & 0.25685 & 0.43695 & -0.14751 & 0.03368 & -4.3803 \\
\hline $\mathrm{T}$ & 14.137 & 10.409 & 0.01415 & 0.00235 & 6.0210 \\
\hline $\mathrm{R}$ & 0.80857 & 0.39348 & -0.36804 & 0.03779 & -9.7404 \\
\hline W & 0.07201 & 0.25853 & 0.23766 & 0.05687 & 4.1787 \\
\hline $\mathrm{C}$ & 0.10066 & 0.30092 & -0.39603 & 0.04864 & -8.1426 \\
\hline $\mathrm{L}$ & 0.08316 & 0.27617 & -0.52661 & 0.05251 & -10.0290 \\
\hline \multirow{2}{*}{$\begin{array}{l}\text { S } \\
\text { INTERCEPT }\end{array}$} & 0.03043 & 0.17178 & -0.17041 & 0.08377 & -2.0343 \\
\hline & & & 4.6179 & 0.16362 & 28.224 \\
\hline $\begin{array}{l}\mathrm{R} 2 \\
\mathrm{~N}\end{array}$ & 0.2158 & & & & \\
\hline \multicolumn{2}{|l|}{$r$} & & 0.27749 & 0.01530 & 18.135 \\
\hline
\end{tabular}


TABLE A 3

REGRESSIONS AND INTRA-CLASS CORRELATIONS FOR INCOME OF FULL BROTHERS

EQUATION 1

\begin{tabular}{lr} 
VARIABLE & \multicolumn{1}{c}{ MEAN } \\
NAME & \\
LNINCOME & 6.06520 \\
AGE & 40.66900 \\
AGE2 & 1806.00000 \\
T & 14.92700 \\
R & 0.80453 \\
FBE & 0.24874 \\
W & 0.07385 \\
C & 0.10357 \\
F & 0.70553 \\
S & 0.03155 \\
L & 0.07842 \\
D55 & 0.02561 \\
D57 & 0.08642 \\
D59 & 0.04527 \\
D61 & 0.11340 \\
D66 & 0.08093 \\
D 70 & 0.07042 \\
D 75 & 0.07042 \\
D 80 & 0.08962 \\
D 85 & 0.13352 \\
D 90 & 0.11203 \\
D 95 & 0.06081 \\
D00 & 0.11157 \\
I T ERCE P &
\end{tabular}

STANDARD

DEVIATION

0.81576

12.33300

1092.30000

11.67000

0.39661

0.43233

0.26155

0.30473

0.45586

0.17482

0.26886

0.15797

0.28102

0.20791

0.31711

0.27276

0.25588

0.25588

0.28567

0.34017

0.31543

0.23902

0.31487
ES T IMA TED

COEFFICIEN T
STANDARD
ERROR
T-RATIO

4341 DF

INTERCEPT

$\begin{array}{ll}\mathrm{R} 2 & 0.0164 \\ \mathrm{~N} & 4347 \\ \mathrm{r} & \end{array}$

\begin{abstract}
0.22369
0.26717

0.21116

0.30976

0.35031

0.14690

0.19951

0.18709

0.16549

0.09852

$-0.04566$
\end{abstract}

5.8918

0.08477

0.05543

0.06817

0.05158

0.05648

0.05808

0.05888

0.05487

0.04962

$0.051 \% 4$

0.06166

0.03662

2.6389

4. 8197

3.0976

6.0050

$6.202 \mathrm{v}$

2.4950

3.3886

3.4095

3.3352

1.9040

$-0.7405$

160.88

0.19378

0.01484

13.060 
TABLEA. 3 (Cont'd)

REGRESSIONS AND INTRA-CLASS CORRELATIONS FOR INCOME OF FULL BROTHERS

\section{EQUATION 2}

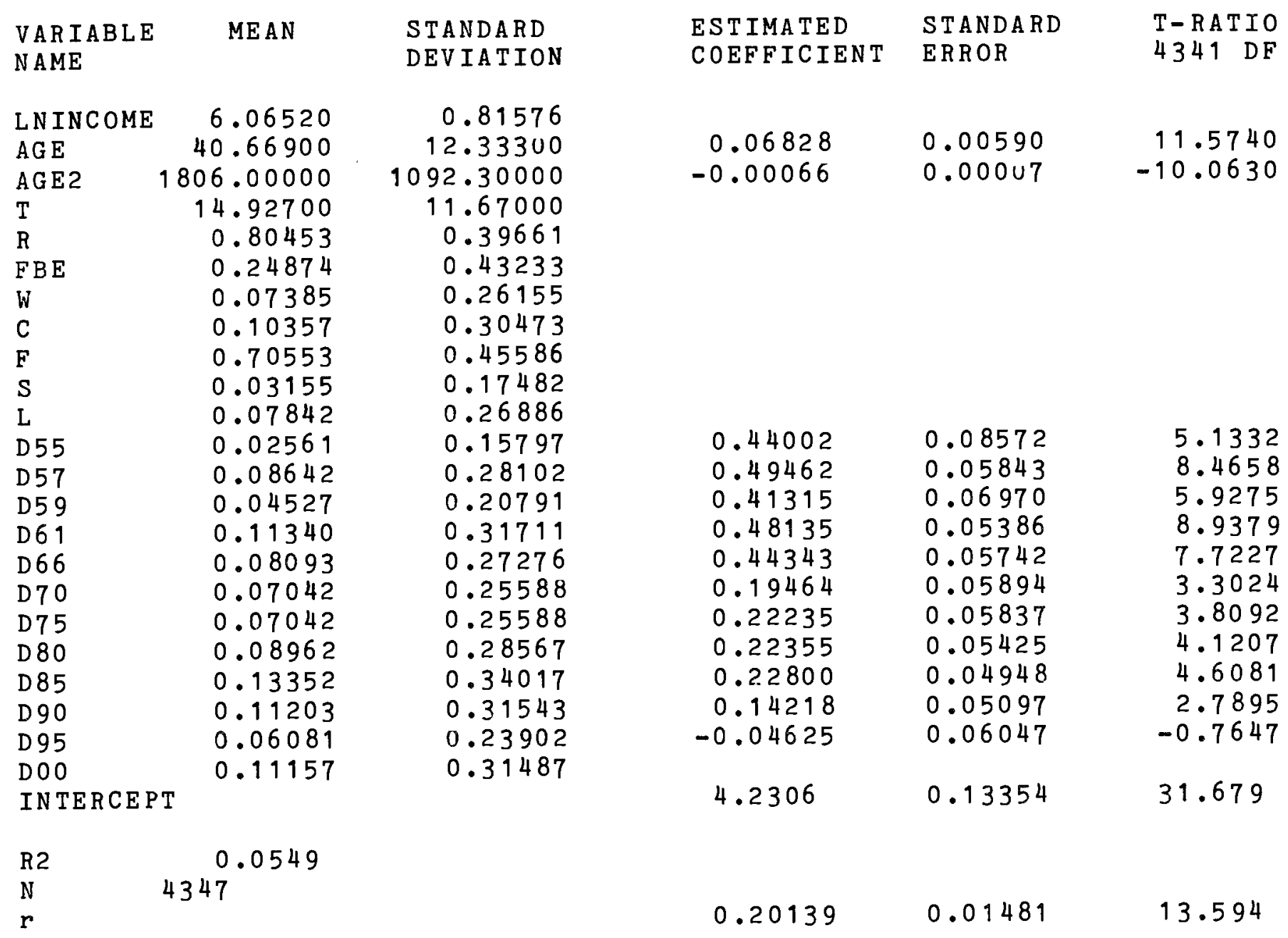


TABLEA. 3 (Cont'd)

REGRESSIONS AND INTRA-CLASS CORRELATIONS FOR INCOME OF FULL BROTHERS

EQUATION 3

\begin{tabular}{|c|c|c|c|c|c|}
\hline $\begin{array}{l}\text { VAR IABLE } \\
\text { NAME }\end{array}$ & MEAN & $\begin{array}{l}\text { STANDARD } \\
\text { DEVIATION }\end{array}$ & $\begin{array}{l}\text { EST IMATED } \\
\text { COEFFICIENT }\end{array}$ & $\begin{array}{l}\text { STANDARD } \\
\text { ERROR }\end{array}$ & $\begin{array}{l}\text { T-RATIO } \\
4341 \text { DF }\end{array}$ \\
\hline LN INCOME & 6.06520 & 0.81576 & & & \\
\hline $\mathrm{AGE}$ & 40.66900 & 12.33300 & 0.06394 & 0.00595 & 10.7480 \\
\hline AGE2 & 1806.00000 & 1092.30000 & -0.00068 & 0.000007 & -10.3500 \\
\hline $\mathrm{T}$ & 14.92700 & 11.67000 & 0.00665 & 0.00213 & 3.1204 \\
\hline $\mathrm{R}$ & 0.80453 & 0.39661 & -0.24124 & 0.03101 & -7.7803 \\
\hline FBE & 0.24874 & 0.43233 & 0.04012 & 0.02840 & 1.4127 \\
\hline$W$ & 0.07385 & 0.26155 & & & \\
\hline C & 0.10357 & 0.30473 & & & \\
\hline $\mathbf{F}$ & 0.70553 & 0.45586 & & & \\
\hline$S$ & 0.03155 & 0.17482 & & & \\
\hline $\mathrm{L}$ & 0.07842 & 0.26886 & & & \\
\hline D 55 & 0.02561 & 0.15797 & 0.48262 & 0.08678 & 5.5615 \\
\hline D 57 & 0.08642 & 0.28102 & 0.49933 & 0.06002 & 8.3198 \\
\hline D59 & 0.04527 & 0.20791 & 0.39610 & 0.07078 & 5.5960 \\
\hline D 61 & 0.11340 & 0.31711 & 0.48599 & 0.05494 & 8.8452 \\
\hline D 66 & 0.08093 & 0.27276 & 0.45296 & 0.05758 & 7.8664 \\
\hline D 70 & 0.07042 & 0.25588 & 0.22070 & 0.05913 & 3.7321 \\
\hline D 75 & 0.07042 & 0.25588 & 0.23333 & 0.05822 & 4.0080 \\
\hline D 80 & 0.08962 & 0.28567 & 0.21405 & 0.05448 & 3.9292 \\
\hline D 85 & 0.13352 & 0.34017 & 0.24592 & 0.04960 & 4.9583 \\
\hline D 90 & 0.11203 & 0.31543 & 0.16436 & 0.05074 & 3.2390 \\
\hline D95 & 0.06081 & 0.23902 & -0.04924 & 0.06014 & -0.8187 \\
\hline D00 & 0.11157 & 0.31487 & & & \\
\hline INTERCEPT & & & 4.5122 & 0.13676 & 32.092 \\
\hline $\mathrm{R} 2$ & 0.0700 & & & & \\
\hline $\mathrm{N}$ & 4347 & & & & \\
\hline$r$ & & & 0.19109 & 0.01485 & 12.873 \\
\hline
\end{tabular}


TABLEA. 3 (Cont'd)

REGRESSIONS AND INTRA-CLASS CORRELATIONS FOR INCOME OF FULL BROTHERS

EQUATION 4

\begin{tabular}{lr} 
VARIABLE & \multicolumn{1}{c}{ MEAN } \\
NAME & \\
LNINCOME & 6.06520 \\
AGE & 40.66900 \\
AGE2 & 1806.00000 \\
T & 14.92700 \\
R & 0.80453 \\
FBE & 0.24874 \\
W & 0.07385 \\
C & 0.10357 \\
F & 0.70553 \\
S & 0.03155 \\
L & 0.07842 \\
D 55 & 0.02561 \\
D 57 & 0.08642 \\
D 59 & 0.04527 \\
D61 & 0.11340 \\
D66 & 0.08093 \\
D 70 & 0.07042 \\
D 75 & 0.07042 \\
D 80 & 0.08962 \\
D 85 & 0.13352 \\
D 90 & 0.11203 \\
D 95 & 0.06081 \\
D 00 & 0.11157 \\
IN1 &
\end{tabular}

INTERCEPT

$\begin{array}{ll}\mathrm{R} 2 & 0.0997 \\ \mathrm{~N} & 4347 \\ \mathrm{r} & \end{array}$

STANDARD DEVIATION

ES T IMATED

COEFFICIENT

0.06291

$-0.00066$

0.00714

$-0.22406$

0.05483

0.46854

$-0.04669$

0.04509

$-0.24000$

0.56417

0.58151

0.46550

0.56099

0.50286

0.26343

0.26338

0.24125

0.26010

0.18370

$-0.03234$

4.4510

0.17855
STANDARD

ERROR

0.00588

0.00007

0.00210

0.03128

0.02807

0.04624

0.03967

0.06811

0.04466

0.08590

0.05972

0.07001

0.05456

0.05695

0.05844

0.05745

0.05378

0.04891

0.05005

0.05925

0.13683

0.01488
I-RAT IO

4341 DF

10.7020

$-10.2490$

3.4009

$-7.1624$

1.0535

10.1340

$-1.1769$

0.6621

$-5.3743$

6.5677

9.7374

6.6488

10.2820

8.8306

4.5078

4.5845

4.4860

5.3176

$3.670 u$

$-0.5458$

32.528 
TABLE A. 4

REGRESSIONS AND INTRA-CLASS CORRELATIONS FOR WEALTH OF FULL BROTHERS

EQUATION 1

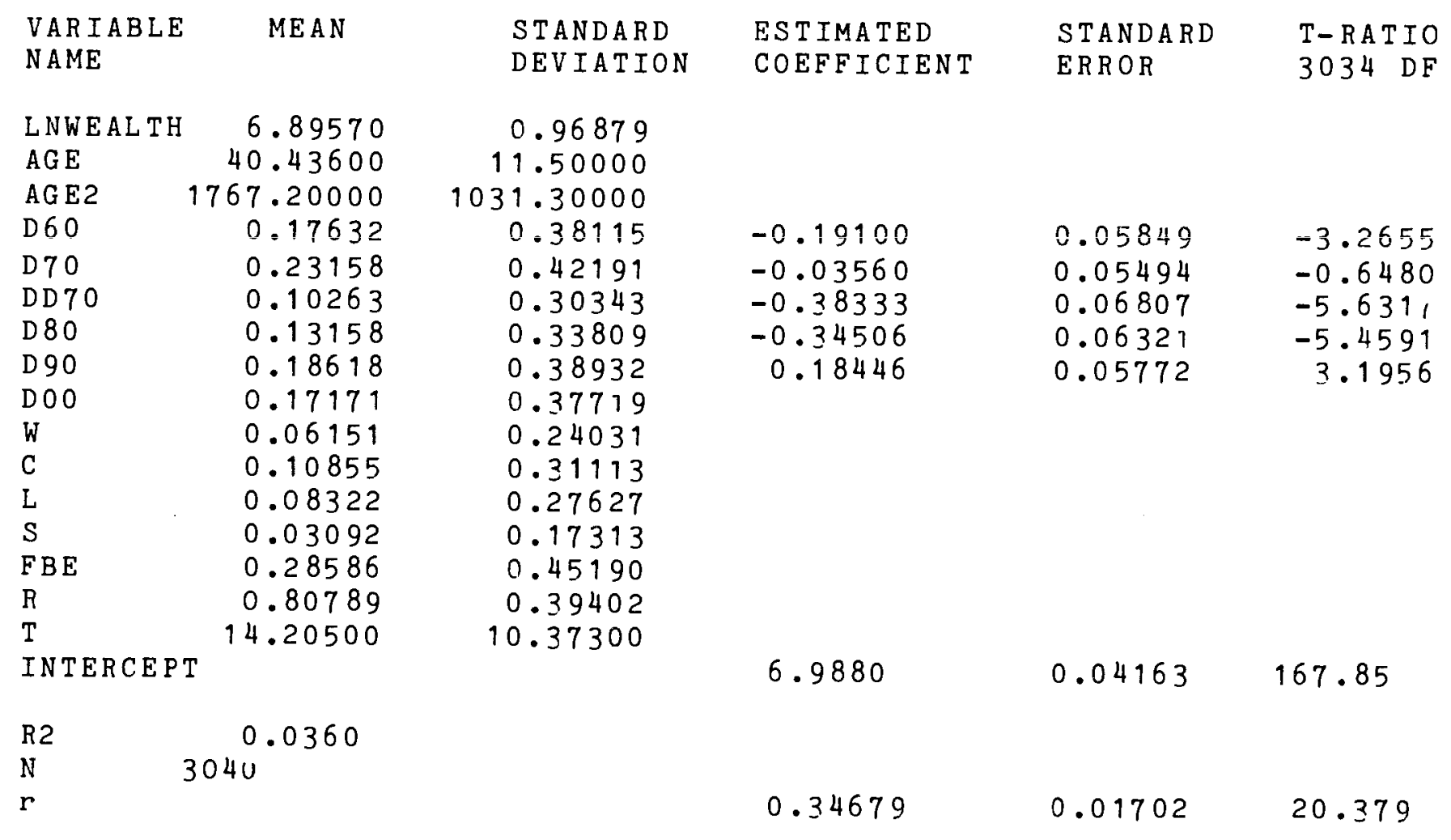


TABLE A. 4 (Cont'd)

REGRESSIONS AND INTRA-CLASS CORRELATIONS FOR WEALTH OF FULL BROTHERS

EQUATION 2

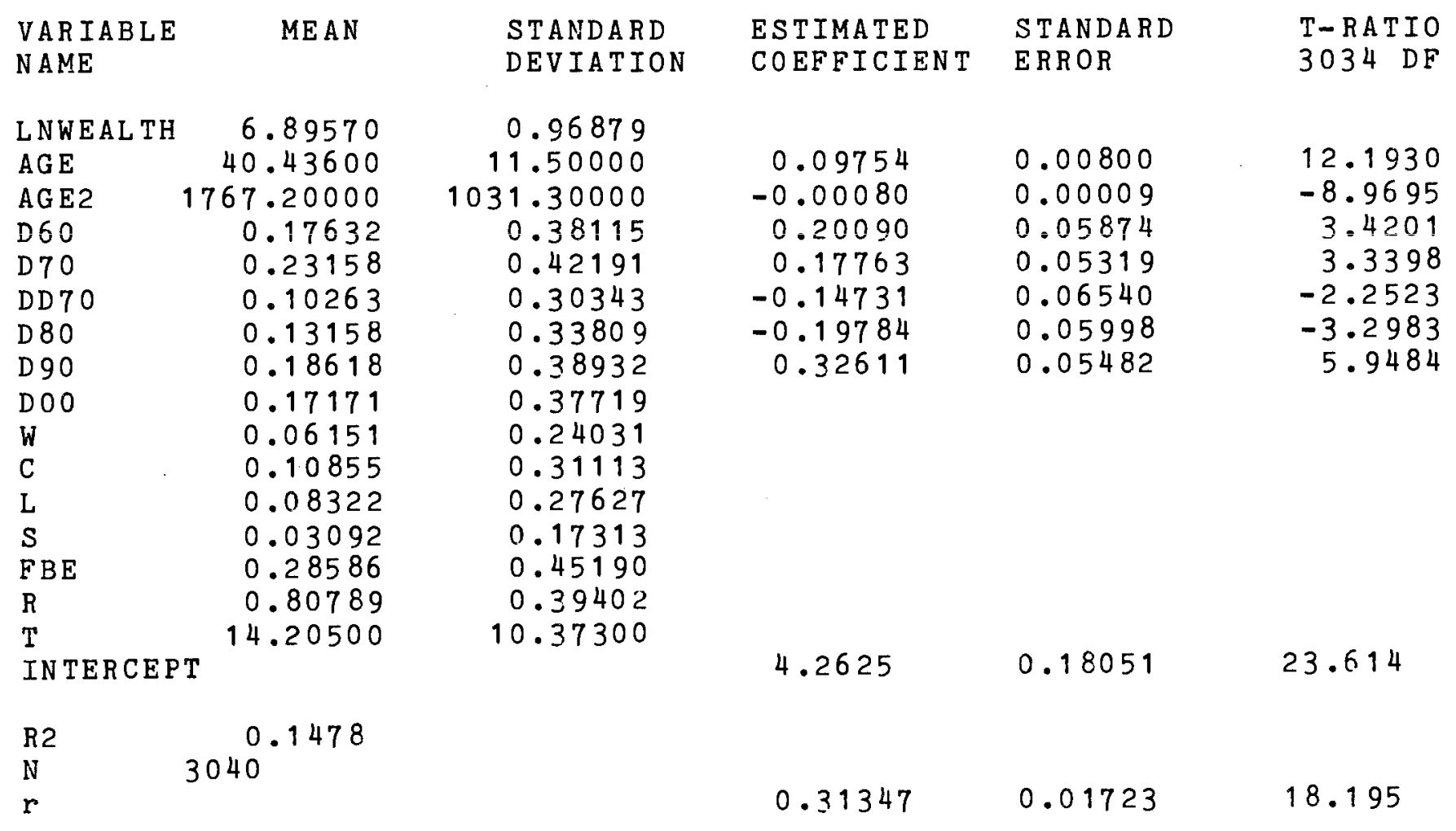


TABLE A. 4 (Cont'd)

REGRESSIONS AND INTRA-CLASS CORRELATIONS FOR WEALTH OF FULL BROTHERS

EQUATION 3

\begin{tabular}{|c|c|c|c|c|c|}
\hline \multirow{2}{*}{$\begin{array}{l}\text { VARIABLE } \\
\text { NAME }\end{array}$} & \multirow{2}{*}{ MEAN } & STANDARD & EST IMATED & TANDARD & T-RATIO \\
\hline & & DEVIATION & COEFFICIENT & ERROR & $3034 \mathrm{DF}$ \\
\hline L NWEAL TH & 6.89570 & 0.96879 & & & \\
\hline $\mathrm{AGE}$ & 40.43600 & 11.50000 & 0.09180 & 0.00797 & 11.5250 \\
\hline AG E2 & 1767.20000 & 1031.30000 & -0.00083 & 0.00009 & -9.4886 \\
\hline D 60 & 0.17632 & 0.38115 & 0.22976 & 0.05985 & 3.8393 \\
\hline D 70 & 0.23158 & 0.42191 & 0.24606 & $0.053 \cup 3$ & 4.6398 \\
\hline DD 70 & 0.10263 & 0.30343 & -0.07528 & 0.06488 & -1.1604 \\
\hline D 80 & 0.13158 & 0.33809 & -0.15646 & 0.05923 & -2.6418 \\
\hline D 90 & 0.18618 & 0.38932 & 0.37057 & 0.05405 & 6.8564 \\
\hline DOO & 0.17171 & 0.37719 & & & \\
\hline$W^{\prime}$ & 0.06151 & 0.24031 & & & \\
\hline $\mathrm{C}$ & 0.10855 & 0.31113 & & & \\
\hline L & 0.08322 & 0.27627 & & & \\
\hline$S$ & 0.03092 & 0.17313 & & & \\
\hline F B E & 0.28586 & 0.45190 & -0.21721 & 0.03595 & -6.0427 \\
\hline $\mathrm{R}$ & 0.80789 & 0.39402 & -0.33804 & 0.04146 & -8.1527 \\
\hline $\mathrm{T}$ & 14.20500 & 10.37300 & 0.01285 & 0.00258 & 4.9800 \\
\hline \multicolumn{6}{|c|}{ INTERCEPT } \\
\hline $\mathrm{R} 2$ & 0.1783 & & & & \\
\hline $\mathrm{N}$ & 3040 & & & & \\
\hline$r$ & & & 0.30289 & 0.01729 & 17.517 \\
\hline
\end{tabular}


TABLE A. 4 (Cont'd)

REGRESSIONS AND INTRA-CLASS CORRELATIONS FOR WEALTH OF FULL BROTHERS

\section{EQUATION 4}

\begin{tabular}{lr} 
VARIABLE & \multicolumn{1}{c}{ MEAN } \\
NAME & \\
LNWEALTH & 6.89570 \\
AGE & 40.43600 \\
AGE2 & 1767.20000 \\
D60 & 0.17632 \\
D70 & 0.23158 \\
DD70 & 0.10263 \\
D 80 & 0.13158 \\
D90 & 0.18618 \\
D00 & 0.17171 \\
W & 0.06151 \\
C & 0.10855 \\
L & 0.08322 \\
S & 0.03092 \\
FBE & 0.28586 \\
R & 0.80789 \\
T & 14.20500 \\
INTERCEPT &
\end{tabular}

$\begin{array}{ll}R 2 & 0.2086 \\ N & 3040\end{array}$

\section{STANDARD}

DEVIATION

0.96879
11.50000
1031.30000
0.38115
0.42191
0.30343
0.33809
0.38932
0.37719
0.24031
0.31113
0.27627
0.17313
0.45190
0.39402
10.37300

0.96879

$\overline{3} 1.30000$

0.38115

0.42191

0.38932

0.37719

0.24031

0.31113

0.27627

0.17313

0.45190

10.37300

$\begin{array}{ll}\text { ESTIMATED } & \text { STANDARD } \\ \text { COEFFICIENT } & \text { ERROR }\end{array}$

0.08659

$-0.00078$

0.30912

0.30290

$-0.02916$

$-0.12335$

$0.377 \% 7$

0.22547

$-0.33499$

$-0.46928$

$-0.24455$

$-0.18481$

$-0.37062$

$0.013 \% 1$

4. 8121

0.28975
0.00788

0.00009

0.05933

0.05243

0.06396

0.05835

0.05318

0.06680

0.05195

0.05805

0.09206

0.03553

$0.0415 b$

0.00254

0.18106
T-RATIO

3034 DF

10.989

$-8.9773$

5.2102

5.7769

$-0.45597$

$-2.1139$

7.1037

3.3755

$-6.4478$

$-8.0845$

$-2.6563$

$-5.201 \mathrm{u}$

$-8.9210$

5.4296

26.577

16.686 
TABLE A . 5

REGRESSIONS AND INTRA-CLASS CORRELATIONS FOR INCOME OF HALF BROTHERS

EQUATION 1

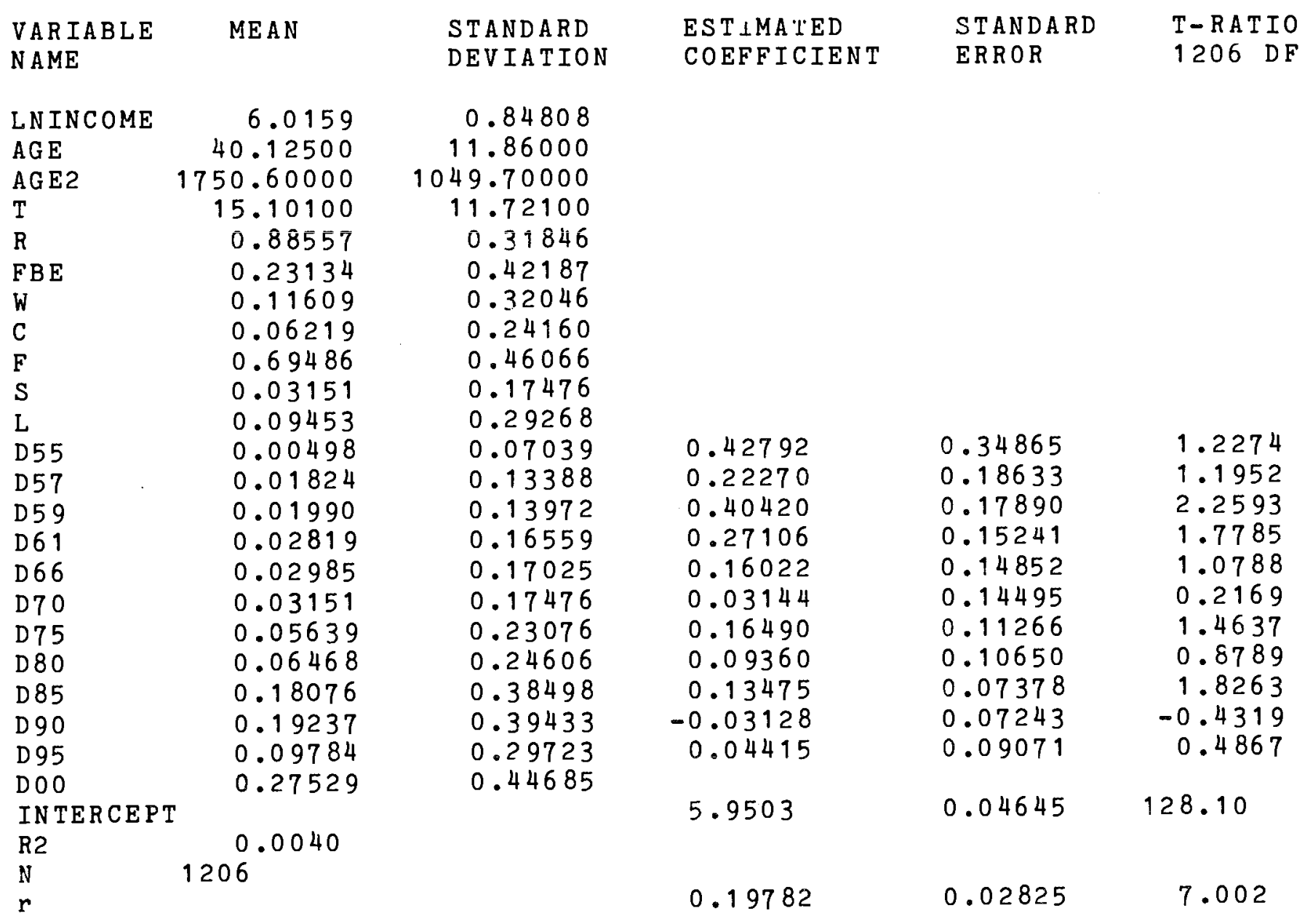


TABLE A. 5 (Cont'd)

REGRESSIONS AND INTRA-CLASS CORRELATIONS FOR INCOME OF HALF BROTHERS

EQUATION 2

\begin{tabular}{|c|c|c|c|c|c|}
\hline $\begin{array}{l}\text { VAR IABLE } \\
\text { NAME }\end{array}$ & MEAN & $\begin{array}{l}\text { STANDARD } \\
\text { DEVIATION }\end{array}$ & $\begin{array}{l}\text { EST IMATED } \\
\text { COEFFICIENT }\end{array}$ & $\begin{array}{l}\text { STANDARD } \\
\text { ERROR }\end{array}$ & $\begin{array}{l}\text { T-RATIO } \\
1206 \text { DF }\end{array}$ \\
\hline $\begin{array}{l}\text { LN IN COME } \\
\text { AGE }\end{array}$ & $\begin{array}{r}6.0159 \\
40.12500\end{array}$ & $\begin{array}{r}0.84808 \\
11.86000\end{array}$ & 0.06909 & 0.01181 & 5.8520 \\
\hline AGE2 & 1750.60000 & 1049.70000 & -0.00071 & 0.00013 & -5.3952 \\
\hline $\mathrm{T}$ & 15.10100 & 11.72100 & & & \\
\hline $\mathrm{R}$ & 0.88557 & 0.31846 & & & \\
\hline F BE & 0.23134 & 0.42187 & & & \\
\hline W & 0.11609 & 0.32046 & & & \\
\hline $\mathrm{C}$ & 0.06219 & 0.24160 & & & \\
\hline $\mathrm{F}$ & 0.69486 & 0.46066 & & & \\
\hline$S$ & 0.03151 & 0.17476 & & & \\
\hline L & 0.09453 & 0.29268 & & & \\
\hline D 55 & 0.00498 & 0.07039 & 0.58815 & 0.34521 & 1.7037 \\
\hline D 57 & 0.01824 & 0.13388 & 0.45228 & 0.18886 & 2.3948 \\
\hline D 59 & 0.01990 & 0.13972 & 0.53057 & 0.17882 & 2.9671 \\
\hline D 61 & 0.02819 & 0.16559 & 0.43192 & 0.15440 & 2.7975 \\
\hline D 66 & 0.02985 & 0.17025 & 0.26074 & 0.14880 & 1.7523 \\
\hline D 70 & 0.03151 & 0.17476 & 0.16472 & 0.14606 & 1.1278 \\
\hline D 75 & 0.05639 & 0.23076 & 0.29045 & $0.114<9$ & 2.5414 \\
\hline D 80 & 0.06468 & 0.24606 & 0.15085 & 0.10621 & 1.4203 \\
\hline D 85 & 0.18076 & 0.38498 & 0.20216 & 0.07492 & 2.6983 \\
\hline D 90 & 0.19237 & 0.39433 & 0.02579 & 0.07310 & 0.3529 \\
\hline D95 & 0.09784 & 0.29723 & 0.04842 & 0.08939 & 0.5417 \\
\hline D 00 & 0.27529 & 0.44685 & & & \\
\hline INTERCEPT & & & 4.3685 & 0.26267 & 16.631 \\
\hline R2 & 0.0329 & & & & \\
\hline $\mathrm{N}$ & 1206 & & & & \\
\hline$r$ & & & 0.20453 & 0.01994 & 10.258 \\
\hline
\end{tabular}


TABLEA. 5 (Cont'd)

\section{REGRESSIONS AND INTRA-CLASS CORRELATIONS FOR INCOME OF HALF BROTHERS}

EQUATION 3

\begin{tabular}{|c|c|c|c|c|c|}
\hline $\begin{array}{l}\text { VAR IABLE } \\
\text { NAME }\end{array}$ & MEAN & $\begin{array}{l}\text { STANDARD } \\
\text { DEVIATION }\end{array}$ & $\begin{array}{l}\text { ESTIMATED } \\
\text { COEFFICIENT }\end{array}$ & $\begin{array}{l}\text { STANDARD } \\
\text { ERROR }\end{array}$ & $\begin{array}{l}\text { T-RATIO } \\
1206 \text { DF }\end{array}$ \\
\hline LN INCOME & 6.0159 & 0.84808 & & & \\
\hline$A G E$ & 40.12500 & 11.86 .000 & 0.05794 & 0.01189 & 4.8738 \\
\hline $\mathrm{AGE} 2$ & 1750.60000 & 1049.70000 & -0.00075 & 0.00013 & -5.7312 \\
\hline $\mathrm{T}$ & 15.10100 & 11.72100 & 0.01871 & 0.00426 & 4.3901 \\
\hline $\mathrm{R}$ & 0.88557 & 0.31846 & -0.38864 & 0.07779 & -4.9961 \\
\hline F BE & 0.23134 & 0.42187 & -0.02936 & 0.06555 & -0.4479 \\
\hline D5 5 & 0.00498 & 0.07039 & 0.82284 & 0.34279 & 2.4004 \\
\hline D 57 & 0.01824 & 0.13388 & 0.52819 & 0.18923 & 2.7913 \\
\hline D 59 & 0.01990 & 0.13972 & 0.58858 & 0.18443 & 3.1913 \\
\hline D 61 & 0.02819 & 0.16559 & 0.46792 & 0.16030 & 2.9190 \\
\hline D 66 & 0.02985 & 0.17025 & 0.35003 & 0.15588 & 2.2456 \\
\hline D 70 & 0.03151 & 0.17476 & 0.25452 & 0.14789 & 1.7210 \\
\hline D 75 & 0.05639 & 0.23076 & 0.37892 & 0.11604 & 3.2653 \\
\hline D 80 & 0.06468 & 0.24606 & 0.21162 & 0.10789 & 1.9615 \\
\hline D 85 & 0.18076 & 0.38498 & 0.27265 & 0.07626 & 3.5753 \\
\hline D 90 & 0.19237 & 0.39433 & 0.12074 & 0.07387 & 1.6345 \\
\hline D 95 & 0.09784 & 0.29723 & 0.06860 & 0.08824 & 0.7774 \\
\hline DOO & 0.27529 & 0.44685 & & & \\
\hline W & 0.11609 & 0.32046 & & & \\
\hline $\mathrm{C}$ & 0.06219 & 0.24160 & & & \\
\hline $\mathrm{F}$ & 0.69486 & 0.46066 & & & \\
\hline$S$ & 0.03151 & 0.17476 & & & \\
\hline L & 0.09453 & 0.29268 & & & \\
\hline INTERCEPT & & & 4.8957 & 0.27183 & 18.010 \\
\hline $\mathrm{R} 2$ & 0.0635 & & & & \\
\hline $\mathrm{N}$ & 1206 & & & & \\
\hline$r$ & & & 0.18889 & 0.02830 & 6.675 \\
\hline
\end{tabular}


TABLE A. 5 (Cont'd)

REGRESSIONS AND INTRA-CLASS CORRELATIONS FOR INCOME OF HALF BROTHERS

EQUATION 4

\begin{tabular}{|c|c|c|c|c|c|}
\hline $\begin{array}{l}\text { VAR I ABLE } \\
\text { NAME }\end{array}$ & MEAN & $\begin{array}{l}\text { STANDARD } \\
\text { DEVIATION }\end{array}$ & $\begin{array}{l}\text { ESTIMATED } \\
\text { COEFFICIENT }\end{array}$ & $\begin{array}{l}\text { STANDARD } \\
\text { ERROR }\end{array}$ & $\begin{array}{l}\text { T-RATIO } \\
1206 \text { DF }\end{array}$ \\
\hline $\begin{array}{l}\text { LN IN COME } \\
\text { AGE }\end{array}$ & $\begin{array}{r}6.0159 \\
40.12500\end{array}$ & $\begin{array}{r}0.84808 \\
11.86000\end{array}$ & 0.05967 & 0.01144 & 5.2179 \\
\hline A E E2 & 1750.60000 & 1049.70000 & -0.00073 & 0.00013 & -5.8091 \\
\hline $\mathrm{T}$ & 15.10100 & 11.72100 & 0.01846 & 0.00410 & 4.5042 \\
\hline $\mathrm{R}$ & 0.88537 & 0.31846 & -0.32528 & 0.07536 & $-4 \cdot 3166$ \\
\hline F B E & 0.23134 & 0.42187 & 0.01091 & 0.06300 & 0.1731 \\
\hline W & 0.11609 & 0.32046 & 0.76947 & 0.07448 & 10.3310 \\
\hline $\mathrm{C}$ & 0.06219 & 0.24160 & -0.13469 & 0.09594 & -1.4040 \\
\hline F & 0.69486 & 0.46066 & & & \\
\hline S & 0.03151 & 0.17476 & -0.06193 & 0.13130 & -0.4717 \\
\hline L & 0.09453 & 0.29268 & -0.03215 & 0.07991 & -0.4023 \\
\hline D 55 & 0.00498 & 0.07039 & 0.98734 & 0.32820 & 3.0084 \\
\hline D 57 & 0.01824 & 0.13388 & 0.72442 & 0.18179 & 3.9850 \\
\hline D 59 & 0.01990 & 0.13972 & 0.66866 & 0.17656 & 3.7873 \\
\hline D 61 & 0.02819 & 0.16559 & 0.61956 & 0.15436 & 4.0136 \\
\hline D 66 & 0.02985 & 0.17025 & 0.44644 & 0.14942 & 2.9878 \\
\hline D 70 & 0.03151 & 0.17476 & 0.41551 & 0.14218 & 2.9224 \\
\hline D 75 & 0.05639 & 0.23076 & 0.48327 & 0.11143 & 4.3370 \\
\hline D 80 & 0.06468 & 0.24606 & 0.33520 & 0.10394 & 3.2250 \\
\hline D 85 & 0.18076 & 0.38498 & 0.36459 & 0.07351 & 4.9599 \\
\hline D 90 & 0.19237 & 0.39433 & 0.18194 & 0.07098 & 2.5634 \\
\hline D 95 & 0.09784 & 0.29723 & 0.11141 & 0.08456 & 1.3175 \\
\hline D 00 & 0.27529 & 0.44685 & & & \\
\hline INTERCEPT & & & 4.5878 & 0.26472 & 17.331 \\
\hline $\mathrm{R} 2$ & 0.1454 & & & & \\
\hline N & 1206 & & & & \\
\hline$r^{*}$ & & & 0.14554 & 0.02651 & 5.105 \\
\hline
\end{tabular}


TABLE A . 6

REGRESSIONS AND INTRA-CLASS CORRELATIONS FOR WEALTH OF HALF BROTHERS

EQUATION 1

\begin{tabular}{|c|c|c|c|c|c|}
\hline $\begin{array}{l}\text { VAR IABLE } \\
\text { NAME }\end{array}$ & MEAN & $\begin{array}{l}\text { STANDARD } \\
\text { DEVIATION }\end{array}$ & $\begin{array}{l}\text { EST TMATED } \\
\text { COEFFICIENT }\end{array}$ & $\begin{array}{l}\text { STANDARD } \\
\text { ERROR }\end{array}$ & $\begin{array}{l}\text { T-RATIO } \\
889 \text { DF }\end{array}$ \\
\hline $\begin{array}{l}\text { LNWEAL TH } \\
\text { AGE } \\
\text { AGE2 }\end{array}$ & $\begin{array}{r}6.80570 \\
39.33100 \\
1667.60000\end{array}$ & $\begin{array}{r}1.11620 \\
10.99100 \\
953.01000\end{array}$ & & & \\
\hline D 60 & 0.02655 & 0.16085 & -0.17295 & 0.23085 & -0.7492 \\
\hline D 70 & 0.10398 & 0.30541 & -0.02652 & 0.12715 & -0.2086 \\
\hline $\begin{array}{l}\text { D D } 70 \\
\text { D } 80 \\
\text { D } 90\end{array}$ & $\begin{array}{l}0.02876 \\
0.10177 \\
0.35398\end{array}$ & $\begin{array}{l}0.16723 \\
0.30251\end{array}$ & $\begin{array}{l}-0.55253 \\
-0.43433\end{array}$ & $\begin{array}{l}0.22239 \\
0.12823\end{array}$ & $\begin{array}{l}-2.4845 \\
-3.3871 \\
2\end{array}$ \\
\hline $\begin{array}{l}\text { D } 90 \\
\text { DOO }\end{array}$ & $\begin{array}{l}0.35398 \\
0.38496\end{array}$ & $\begin{array}{l}0.47847 \\
0.48685\end{array}$ & 0.28198 & 0.08472 & 3.3284 \\
\hline$W$ & 0.10730 & 0.30967 & & & \\
\hline C & 0.07412 & 0.26210 & & & \\
\hline L & 0.08297 & 0.27598 & & & \\
\hline$S$ & 0.02876 & 0.16723 & & & \\
\hline F B E & 0.15929 & 0.36615 & & & \\
\hline $\begin{array}{l}R \\
T\end{array}$ & $\begin{array}{r}0.81084 \\
13.91000\end{array}$ & $\begin{array}{r}0.39185 \\
10.53300\end{array}$ & & & \\
\hline \multicolumn{2}{|c|}{ INTERCEPT } & 10.53300 & 6.7734 & 0.059 & 115.52 \\
\hline $\begin{array}{l}\mathrm{R} 2 \\
\mathrm{~N}\end{array}$ & $\begin{array}{l}0.0396 \\
904\end{array}$ & & & & \\
\hline r & & & 0.21203 & 0.03254 & 6.516 \\
\hline
\end{tabular}


TABLE A. 6 (Cont'd)

REGRESSIONS AND INTRA-CLASS CORRELATIONS FOR WEALTH OF HALF BROTHERS

EQUATION 2

\begin{tabular}{|c|c|c|c|c|c|}
\hline $\begin{array}{l}\text { VAR I ABLE } \\
\text { NAME }\end{array}$ & MEAN & $\begin{array}{l}\text { STANDARD } \\
\text { DEVIATION }\end{array}$ & $\begin{array}{l}\text { EST IMATED } \\
\text { COEFFICIENT }\end{array}$ & $\begin{array}{l}\text { STANDARD } \\
\text { ERROR }\end{array}$ & $\begin{array}{l}\text { T- RA T IO } \\
889 \text { DF }\end{array}$ \\
\hline $\begin{array}{l}\text { LNWEALTH } \\
\text { AGE } \\
\text { AGE2 } \\
\text { D 60 } \\
\text { D 70 } \\
\text { D D 70 } \\
\text { D 80 } \\
\text { D 90 } \\
\text { D 00 } \\
\text { W } \\
\text { C } \\
\text { L } \\
\text { S } \\
\text { FBE } \\
\text { R } \\
\text { T }\end{array}$ & $\begin{array}{r}6.80570 \\
39.33100 \\
1667.60000 \\
0.02655 \\
0.10398 \\
0.02876 \\
0.10177 \\
0.35398 \\
0.38496 \\
0.10730 \\
0.07412 \\
0.08297 \\
0.02876 \\
0.15929 \\
0.81084 \\
13.91000\end{array}$ & $\begin{array}{r}1.11620 \\
10.99100 \\
953.01000 \\
0.16085 \\
0.30541 \\
0.16723 \\
0.30251 \\
0.47847 \\
0.48685 \\
0.30967 \\
0.26210 \\
0.27598 \\
0.16723 \\
0.36615 \\
0.39185 \\
10.53300\end{array}$ & $\begin{array}{r}0.09393 \\
-0.00063 \\
0.48980 \\
0.29903 \\
0.06763 \\
-0.05056 \\
0.59826\end{array}$ & $\begin{array}{l}0.01796 \\
0.00021 \\
0.22126 \\
0.12109 \\
0.21281 \\
0.12317 \\
0.08290\end{array}$ & $\begin{array}{r}5.2311 \\
-3.0934 \\
2.2137 \\
2.4694 \\
0.3178 \\
-0.4105 \\
7.2170\end{array}$ \\
\hline INTERCEPT & & & 3.9150 & 0.390 & 10.031 \\
\hline $\begin{array}{l}\mathrm{R} 2 \\
\mathrm{~N} \\
\mathrm{r}\end{array}$ & $90 \frac{0.1729}{}$ & & 0.27051 & 0.03205 & 8.439 \\
\hline
\end{tabular}


TABLE A. 6 (Cont'd)

REGRESSIONS AND INTRA-CLASS CORRELATIONS FOR

WEALTH OF HALF BROTHERS

EQUATION 3

\begin{tabular}{|c|c|c|c|c|c|}
\hline $\begin{array}{l}\text { VAR I ABLE } \\
\text { NAME }\end{array}$ & MEAN & $\begin{array}{l}\text { STANDARD } \\
\text { DEVIATION }\end{array}$ & $\begin{array}{l}\text { ESTIMATED } \\
\text { COEFFICIENT }\end{array}$ & $\begin{array}{l}\text { STANDARD } \\
\text { ERROR }\end{array}$ & $\begin{array}{l}\text { T-RATIO } \\
889 \text { DF }\end{array}$ \\
\hline L NWEAL TH & 6.80570 & 1.11620 & & & \\
\hline $\mathrm{AGE}$ & 39.33100 & 10.99100 & 0.09619 & 0.01794 & 5.3604 \\
\hline$A G E 2$ & 1667.60000 & 953.01000 & -0.00074 & 0.00021 & -3.6162 \\
\hline D 60 & 0.02655 & 0.16085 & 0.37469 & 0.23087 & 1.6229 \\
\hline D 70 & 0.10398 & 0.30541 & 0.38589 & $0.129 y 7$ & 2.9691 \\
\hline D D 70 & 0.02876 & 0.16723 & 0.21007 & 0.21556 & 0.9745 \\
\hline D 80 & 0.10177 & 0.30251 & -0.00771 & 0.12266 & -0.6283 \\
\hline D 90 & 0.35398 & 0.47847 & 0.67350 & 0.08375 & 8.0419 \\
\hline DOO & 0.38496 & 0.48685 & & & \\
\hline FBE & 0.15929 & 0.36615 & -0.00473 & 0.10347 & $\begin{array}{l}-0.4575 \\
-4.880 ?\end{array}$ \\
\hline $\mathrm{R}$ & 0.81084 & 0.39185 & -0.43687 & 0.08952 & -4.8802 \\
\hline $\mathrm{T}$ & 13.91000 & 10.53300 & 0.00952 & 0.00627 & 1.5174 \\
\hline W & 0.10730 & 0.30967 & & & \\
\hline $\mathrm{C}$ & 0.07412 & 0.26210 & & & \\
\hline L & 0.08297 & 0.27598 & & & \\
\hline S & 0.02876 & 0.16723 & & & \\
\hline \multicolumn{2}{|l|}{ INTERCEPT } & & 4.1889 & 0.39289 & 10.662 \\
\hline $\mathrm{R} 2$ & 0.1926 & & & & \\
\hline $\mathrm{N}$ & 904 & & & & \\
\hline $\mathrm{r}$ & & & 0.25524 & 0.03219 & 7.928 \\
\hline
\end{tabular}


TABLE A. 6 (Cont'd)

REGRESSIONS AND INTRA-CLASS CORRELATIONS FOR WEALTH OF HALF BROTHERS

EQUATION 4

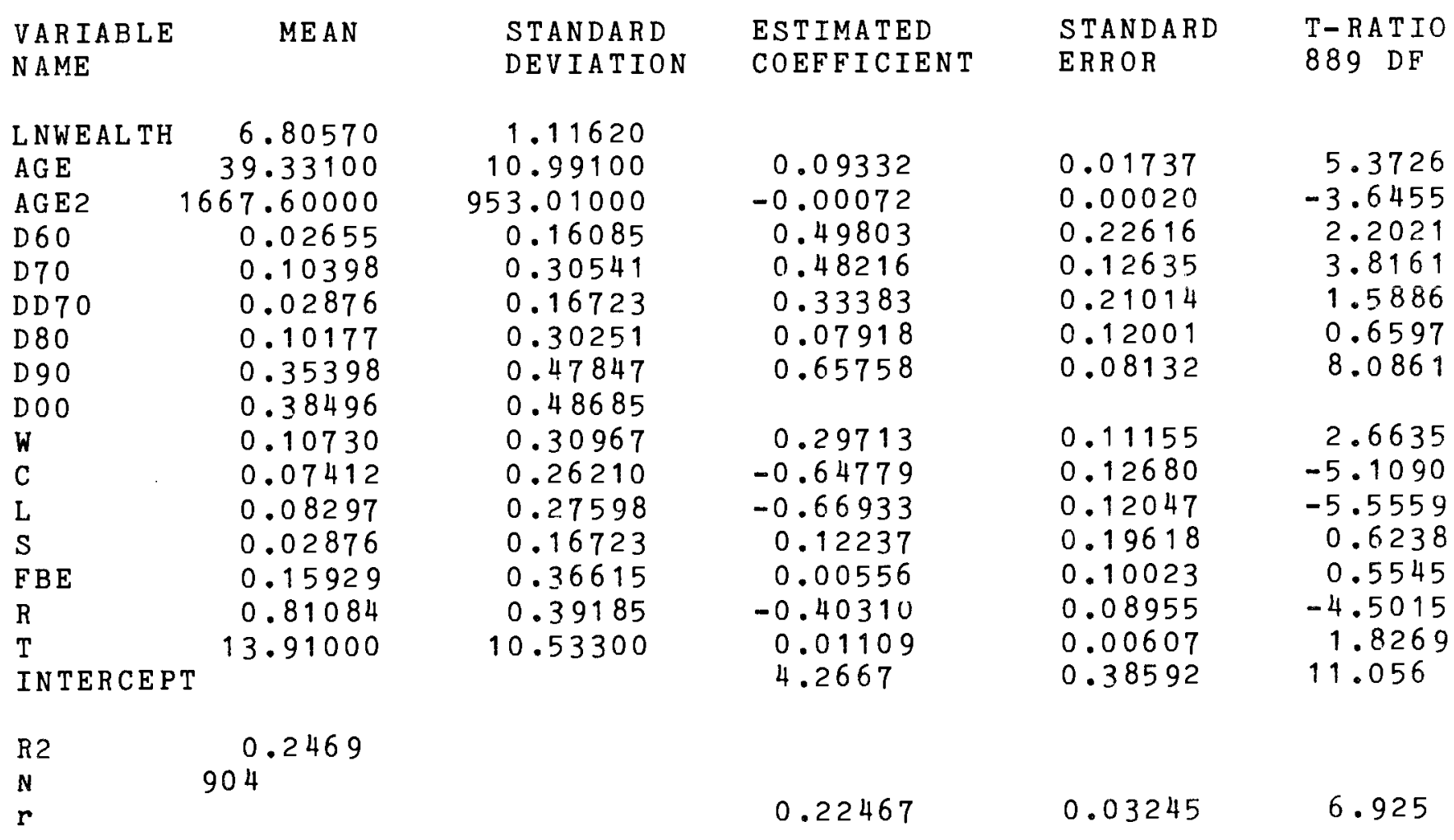


TABLE A. 7

REGRESSIONS AND INTRA-CLASS CORRELATIONS FOR INCOME OF FATHERS AND SONS

EQUATION 1

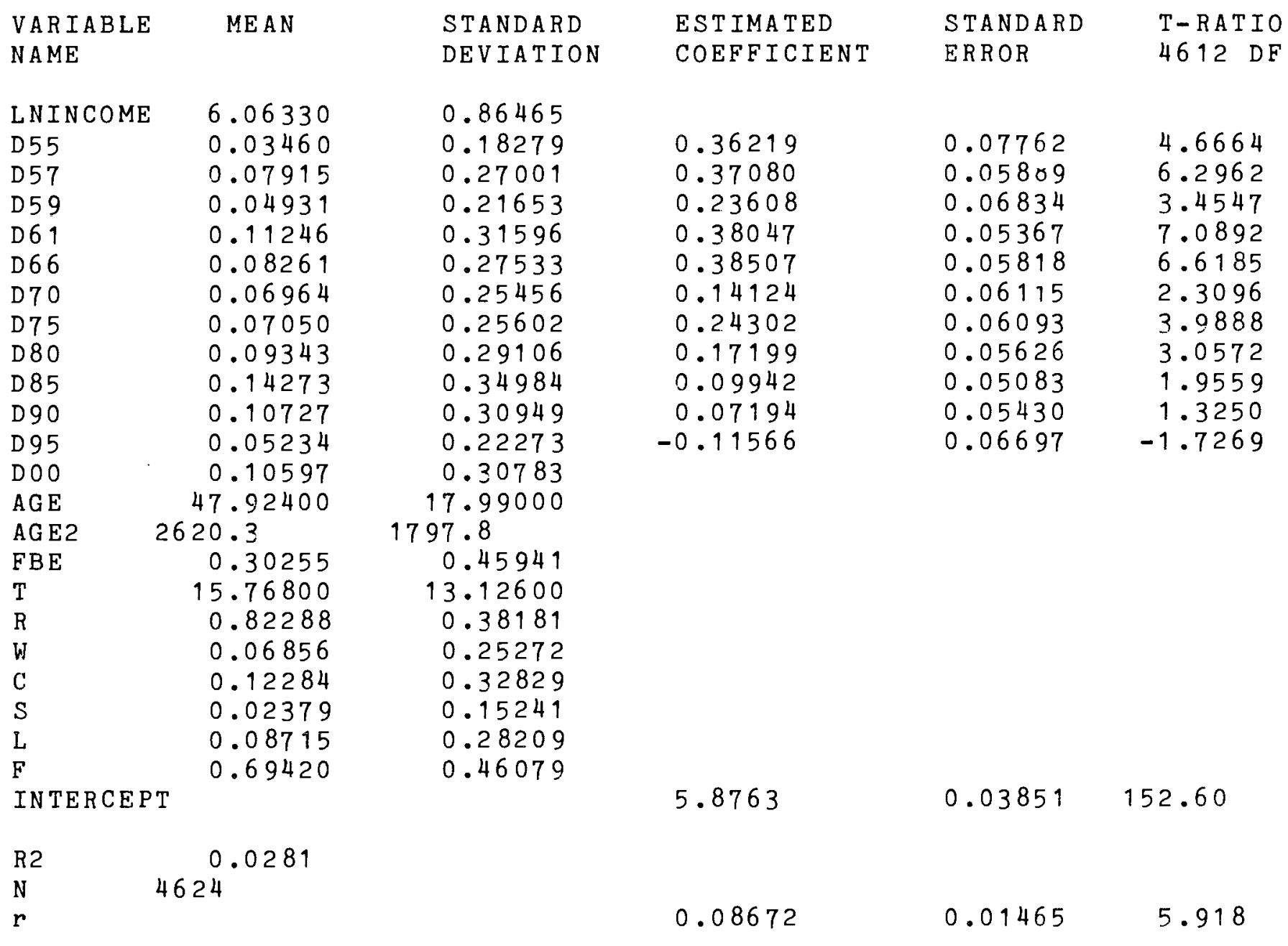


TABLE A. 7 (Cont'd)

REGRESSIONS AND INTRA-CLASS CORRELATIONS FOR

INCOME OF FATHERS AND SONS

EQUATION 2

VARIABLE MEAN N AME

$\begin{array}{lc}\text { LNINCOME } & 6.06330 \\ \text { D55 } & 0.03460 \\ \text { D57 } & 0.07915 \\ \text { D59 } & 0.0493 \\ \text { D61 } & 0.11246 \\ \text { D66 } & 0.0826 \\ \text { D 70 } & 0.06964 \\ \text { D75 } & 0.07050 \\ \text { D 80 } & 0.09343 \\ \text { D 85 } & 0.14273 \\ \text { D 90 } & 0.10727 \\ \text { D95 } & 0.05234 \\ \text { D 0 } & 0.10597 \\ \text { AGE } & 47.924 \\ \text { AGE2 } & 2620.3 \\ \text { FBE } & 0.30255 \\ \text { T } & 15.768 \\ \text { R } & 0.82288 \\ \text { W } & 0.06856 \\ \text { C } & 0.12284 \\ \text { S } & 0.02379 \\ \text { L } & 0.08715 \\ \text { IN TERCEPT } & \\ \text { R2 } & 0.1073 \\ \text { N } & 4624 \\ \text { r } & \end{array}$

\section{STANDARD}

DEVIATION

ESTIMATED
COEFFICIENT

0.42481

0.43003

0.28086

0.40109

0.37150

0.13025

0.24540

0.18901

0.12060

0.07850

$-0.11063$

0.07787

$-0.00073$

1797.8

$$
0.45941
$$

13.126

0.38181

0.25272

0.32829

0.15241

0.2 .8209
STANDARD T-RATIO

ERROR 4612 DF

0.07500

0.05719

0.06605

0.05201

0.05609

0.05880

0.05856

0.05412

0.04888

0.05215

0.06419

0.00398

0.00004

$$
\begin{array}{r}
5.6639 \\
7.5197 \\
4.2525 \\
7.7114 \\
6.6239 \\
2.2154 \\
4.1909 \\
3.4926 \\
2.4670 \\
1.5054 \\
-1.7234 \\
19.547 \\
-18.329
\end{array}
$$

4.0453

0.09757

41.462

0.18180

0.01446

12.569 
TABLE A. 7 (Cont'd)

REGRESSIONS AND INTRA-CLASS CORRELATIONS FOR INCOME OF FATHERS AND SONS

EQUATION 3

\begin{tabular}{lr} 
VARIABLE & \multicolumn{1}{l}{ MEAN } \\
NAME & \\
LNINCOME & 6.0633 \\
D55 & 0.03460 \\
D57 & 0.07915 \\
D59 & 0.04931 \\
D61 & 0.11246 \\
D66 & 0.08261 \\
D70 & 0.06964 \\
D75 & 0.07050 \\
D80 & 0.09343 \\
D85 & 0.14273 \\
D90 & 0.10727 \\
D95 & 0.05234 \\
D00 & 0.10597 \\
AGE & 47.924 \\
AGE2 & 2620.3 \\
F BE & 0.30255 \\
T & 15.768 \\
R & 0.82288 \\
W & 0.06856 \\
C & 0.12284 \\
S & 0.02379 \\
L & 0.08715 \\
IN TERE PT &
\end{tabular}

IN TERCEPT

$\begin{array}{ll}\mathrm{R} 2 & 0.1250 \\ \mathrm{~N} & 4624 \\ \mathrm{r} & \end{array}$

\section{STANDARD \\ DEVIATION}

0.86465

0.18279

0.27001

$0.2165 \overline{3}$

0.31596

0.27533

0.25456

0.25602

0.29106

0.34984

0.30949

0.22273

0.30783

17.990

1797.8

0.45941

13.126

0.38181

0.25272

0.32829

0.15241

0.28209
ESTIMATED

COEFFICIENT

0.66891

0.64756

0.47662

0.60825

0.55628

0.29862

0.38106

0.28702

0.22474

0.15147

$-0.07967$

0.07018

$-0.00071$

$-0.02113$

0.01354

$-0.16823$

4.1702

0.10031

41.571

T-RAT I O

4612 DF

0.08129

8.2284

0.06503

0.07176

0.05865

0.06052

0.06156

0.06033

0.05552

0.04982

0.05232

0.06365

0.00408

0.00004

0.02602

0.00167

0.03212

9.9581

6.6419

10.371

9. 1911

4.8510

6.3165

5.1698

4.5106

2.8954

$-1.2517$

17.207

$-18.006$

$-0.79378$

8.0994

$-5.2368$

0.17357

0.01449

11.982 
TABLE A. 7 (Cont'd)

REGRESSIONS AND INTRA-CLASS CORRELATIONS FOR INCOME OF FATHERS AND SONS

EQUATION 4

\begin{tabular}{|c|c|c|c|c|c|}
\hline VAR I ABLE & MEAN & STANDARD & ESTIMATED & STANDARD & T-RATIO \\
\hline N AME & & DEVIATION & COEFFICIENT & E R ROR & $4612 \mathrm{DF}$ \\
\hline $\begin{array}{l}\text { LN INCOME } \\
\text { D } 55\end{array}$ & $\begin{array}{l}6.0633 \\
0.03460\end{array}$ & $\begin{array}{l}0.86465 \\
0.18279\end{array}$ & 072876 & 008081 & 9.0187 \\
\hline $\begin{array}{l}\text { D } 55 \\
\text { D } 57\end{array}$ & 0.07915 & 0.27001 & 0.70863 & 0.06483 & $\begin{array}{r}9.0187 \\
10.930\end{array}$ \\
\hline D 59 & 0.04931 & 0.21653 & 0.53168 & 0.07135 & 7.4520 \\
\hline D 61 & 0.11246 & 0.31596 & 0.67045 & 0.05848 & $11=464$ \\
\hline D 66 & 0.08261 & 0.27533 & 0.61288 & 0.06014 & 10.191 \\
\hline D 70 & 0.06964 & 0.25456 & 0.34377 & 0.06107 & 5.6288 \\
\hline D 75 & 0.07050 & 0.25602 & 0.40156 & 0.05972 & 6.7238 \\
\hline D 80 & 0.09343 & 0.29106 & 0.32834 & 0.05513 & 5.9561 \\
\hline D 85 & 0.14273 & 0.34984 & 0.23521 & 0.04930 & 4.7707 \\
\hline D 90 & 0.10727 & 0.30949 & 0.16355 & 0.05176 & 3.1597 \\
\hline D 95 & 0.05234 & 0.22273 & -0.07467 & 0.06294 & -1.1863 \\
\hline DOO & 0.10597 & 0.30783 & & & \\
\hline$A G E$ & 47.924 & 17.990 & 0.06852 & 0.00405 & 16.913 \\
\hline A G E2 & 2620.3 & 1797.8 & -0.00069 & 0.00004 & -17.595 \\
\hline F BE & 0.30255 & 0.45941 & -0.00528 & 0.02647 & -0.19959 \\
\hline $\mathrm{T}$ & 15.768 & 13.126 & 0.01365 & 0.00165 & 8.2519 \\
\hline $\mathrm{R}$ & 0.82288 & 0.38181 & -0.16374 & 0.03198 & -5.1207 \\
\hline W & 0.06856 & 0.25272 & 0.42561 & 0.04813 & 8.8433 \\
\hline C & 0.12284 & 0.32829 & -0.12843 & 0.03673 & -3.4967 \\
\hline$S$ & 0.02379 & 0.15241 & -0.02483 & 0.07819 & -0.31700 \\
\hline $\mathrm{L}$ & 0.08715 & 0.28209 & -0.16480 & 0.04274 & -3.8563 \\
\hline INTERCEPI & & & 4.1524 & 0.10159 & 40.873 \\
\hline $\mathrm{R} 2$ & 0.1460 & & & & \\
\hline & & & & & \\
\hline & & & 0.15239 & 0.01454 & 10.483 \\
\hline
\end{tabular}


TABLE A. 8

REGRESSIONS AND INTRA-CLASS CORRELATIONS FOR WEALTH OF FATHERS AND SONS

EQUATION 1

\begin{tabular}{|c|c|c|c|c|c|}
\hline $\begin{array}{l}\text { VAR IABLE } \\
\text { NAME }\end{array}$ & MEAN & $\begin{array}{l}\text { STANDARD } \\
\text { DEVIATION }\end{array}$ & $\begin{array}{l}\text { ESTIMATED } \\
\text { COEFFICIENT }\end{array}$ & $\begin{array}{l}\text { STANDARD } \\
\text { ERROR }\end{array}$ & $\begin{array}{l}\text { T- RATIO } \\
2760 \text { DF }\end{array}$ \\
\hline L NWE AL TH & 6.9730 & 1.0276 & & & \\
\hline D 60 & 0.19089 & 0.39307 & -0.12799 & 0.06301 & -2.0312 \\
\hline D 70 & 0.25958 & 0.43848 & 0.06790 & 0.05880 & 1.1547 \\
\hline D D 70 & 0.09472 & 0.29288 & -0.17577 & 0.07707 & -2.2808 \\
\hline D 80 & 0.11569 & 0.31991 & -0.25849 & 0.07232 & -3.5740 \\
\hline D 90 & 0.15691 & 0.36378 & 0.34765 & 0.06626 & 5.2468 \\
\hline D 00 & 0.18221 & 0.38609 & & & \\
\hline AGE & 50.528 & 17.759 & & & \\
\hline $\mathrm{AGE} 2$ & 2868.3 & 1866.3 & & & \\
\hline F B E & 0.33044 & 0.47046 & & & \\
\hline $\mathrm{T}$ & 17.910 & 12.332 & & & \\
\hline $\mathrm{R}$ & 0.82538 & 0.37971 & & & \\
\hline W & 0.06580 & 0.24798 & & & \\
\hline $\mathrm{C}$ & 0.12473 & 0.33047 & & & \\
\hline $\mathrm{L}$ & 0.09436 & 0.29238 & & & \\
\hline S & 0.02965 & 0.16964 & & & \\
\hline INTERCEPT & & & 6.9718 & 0.04507 & 154.69 \\
\hline $\mathrm{R} 2$ & 0.0304 & & & & \\
\hline $\mathrm{N}$ & 2766 & & & & \\
\hline $\mathbf{r}$ & & & 0.09751 & 0.01893 & 5.151 \\
\hline
\end{tabular}


TABLE A, 8 (Cont'd)

REGRESSIONS AND INTRA-CLASS CORRELATIONS FOR WEALTH OF FATHERS AND SONS

\section{EQUATION 2}

\begin{tabular}{|c|c|c|c|c|c|}
\hline VARIABLE & MEAN & STANDARD & EST IMATED & STANDARD & T-RAT IO \\
\hline NAME & & DEVIATION & COEFFICIENT & ERROR & $2760 \mathrm{DF}$ \\
\hline LNWEALTH & 6.9730 & 1.0276 & & & \\
\hline D 60 & 0.19089 & 0.39307 & 0.00569 & 0.06068 & 0.0938 \\
\hline D 70 & 0.25958 & 0.43848 & 0.13504 & 0.05602 & 2.4108 \\
\hline D D 70 & 0.09472 & 0.29288 & -0.12495 & 0.07302 & -1.7112 \\
\hline D 80 & 0.11569 & 0.31991 & -0.24061 & 0.06833 & -3.5210 \\
\hline D 90 & 0.15691 & 0.36378 & 0.35748 & 0.06265 & 5.7064 \\
\hline D 00 & 0.18221 & 0.38609 & & & \\
\hline A G E & 50.528 & 17.759 & 0.09538 & 0.00651 & 14.660 \\
\hline A GE2 & 2868.3 & 1866.3 & -0.00078 & 0.00006 & $-12 \cdot 584$ \\
\hline F B E & 0.33044 & 0.47046 & & & \\
\hline $\mathrm{T}$ & 17.910 & 12.332 & & & \\
\hline $\mathrm{R}$ & 0.82538 & 0.37971 & & & \\
\hline $\mathrm{W}$ & 0.06580 & 0.24798 & & & \\
\hline C & 0.12473 & 0.33047 & & & \\
\hline $\mathrm{L}$ & 0.09436 & 0.29238 & & & \\
\hline S & 0.02965 & 0.16964 & & & \\
\hline INTERCEPT & & & 4.3378 & 0.16130 & 26.893 \\
\hline $\begin{array}{l}\mathrm{R} 2 \\
\mathrm{~N}\end{array}$ & 0.1397 & & & & \\
\hline$r$ & & & 0.21714 & 0.01857 & 11.695 \\
\hline
\end{tabular}


TABLE A. 8 (Cont'd)

\section{REGRESSIONS AND INTRA-CLASS CORRELATIONS FOR WEALTH OF FATHERS AND SONS}

EQUATION 3

\begin{tabular}{|c|c|c|c|c|c|}
\hline VAR IA B LE & MEAN & STANDARD & ESTIMATED & STANDARD & T-RATIO \\
\hline NAME & & DEVIATION & COEFFICIENT & ERROR & $2760 \mathrm{DF}$ \\
\hline LNWEALTH & 6.9730 & 1.0276 & & & \\
\hline D 60 & 0.19089 & 0.39307 & 0.45449 & 0.07368 & 6.1681 \\
\hline D 70 & 0.25958 & 0.43848 & 0.47995 & 0.06212 & 7.7265 \\
\hline DD 70 & 0.09472 & 0.29288 & 0.22281 & 0.07677 & 2.9024 \\
\hline D 80 & 0.11569 & 0.31991 & -0.00687 & 0.06904 & -0.0996 \\
\hline D 90 & 0.15691 & 0.36378 & 0.47585 & 0.06098 & 7.8034 \\
\hline D 00 & 0.18221 & 0.38609 & & & \\
\hline AGE & 50.528 & 17.759 & 0.08541 & 0.00635 & 13.443 \\
\hline $\begin{array}{l}\text { AGE2 } \\
\text { FBE }\end{array}$ & $\begin{array}{rl}2868 & .3 \\
0.33044\end{array}$ & $\begin{array}{rl}1866 & .3 \\
0.47046\end{array}$ & -0.00078 & 0.00006 & $-13 \cdot 130$ \\
\hline $\mathrm{T}$ & 17.910 & 12.332 & 0.02834 & 0.00247 & 11.481 \\
\hline $\mathrm{R}$ & 0.82538 & 0.37971 & -0.35858 & 0.04656 & -7.7021 \\
\hline $\mathrm{W}$ & 0.06580 & 0.24798 & & & \\
\hline C & 0.12473 & 0.33047 & & & \\
\hline $\mathrm{L}$ & 0.09436 & 0.29238 & & & \\
\hline $\mathrm{S}$ & 0.02965 & 0.16964 & & & \\
\hline INTERCEPT & & & 4.4666 & 0.16294 & 27.413 \\
\hline $\mathrm{R} 2$ & 0.2036 & & & & \\
\hline $\mathrm{N}$ & 2766 & & & & \\
\hline $\mathbf{r}$ & & & 0.20402 & 0.01862 & 10.957 \\
\hline
\end{tabular}


TABLE A. 8 (Cont'd)

REGRESSIONS AND INTRA-CLASS CORRELATIONS FOR WEALTH OF FATHERS AND SONS

\section{EQUATION 4}

\begin{tabular}{|c|c|c|c|c|c|}
\hline VAR I ABLE & MEAN & STANDARD & ESTIMATED & STANDARD & T-RATIO \\
\hline NAME & & DEV I ATION & COEFFICIENT & & 2760 DF \\
\hline LNWE AL TH & 6.9730 & 1.0276 & & & \\
\hline D 60 & 0.19089 & 0.39307 & 0.49707 & 0.07271 & 6.8366 \\
\hline D 70 & 0.25958 & 0.43848 & 0.52379 & 0.06116 & 8.5642 \\
\hline D D 70 & 0.09472 & 0.29288 & 0.26995 & 0.07555 & 3.5733 \\
\hline D 80 & 0.11569 & 0.31991 & 0.02091 & 0.06777 & 0.30847 \\
\hline D 90 & 0.15691 & 0.36378 & 0.46673 & 0.05979 & 7.8067 \\
\hline D 00 & 0.18221 & 0.38609 & & & \\
\hline AGE & 50.528 & 17.759 & 0.07942 & 0.00630 & 12.598 \\
\hline AGE2 & 2868.3 & $1866 \cdot 3$ & -0.00072 & 0.00006 & -12.109 \\
\hline F B E & 0.33044 & 0.47046 & -0.19344 & 0.03730 & -5.1858 \\
\hline $\mathrm{T}$ & 17.910 & 12.332 & 0.02718 & 0.00242 & 11.222 \\
\hline $\mathrm{R}$ & 0.82538 & 0.37971 & -0.36945 & 0.04613 & -8.0087 \\
\hline W & 0.06580 & 0.24798 & 0.44178 & 0.07133 & 6.1939 \\
\hline C & 0.12473 & 0.33047 & -0.27043 & 0.05353 & -5.0523 \\
\hline L & 0.09436 & 0.29238 & -0.41046 & 0.06039 & -6.7973 \\
\hline & 0.02965 & 0.16964 & -0.03214 & 0.10192 & -0.31536 \\
\hline INTERCEPT & & & 4.6128 & 0.16319 & 28.266 \\
\hline $\mathrm{R} 2$ & 0.2351 & & & & \\
\hline N & 2766 & & 0189112 & 0,01871 & 9.700 \\
\hline $\mathbf{r}$ & & & 0.10143 & 1 & 9.100 \\
\hline
\end{tabular}


TABLE A. 9

REGRESSIONS AND INTRA-CLASS CORRELATIONS FOR

INCOME OF BROTHERS

(WITH FATHER'S CHARACTERISTICS)

EQUATION 1

VARIABLE MEAN
NAME

LN IN COME

AGE

AGE2

W

C

F

$S$

L

FBE

$\mathrm{T}$

$\mathrm{R}$

D 55

D 57

D5 9

D 61

D 66

D 70

D75

D 80

D 85

D 90

D 95

D 00

LNF INCOME

FAGE

FAGE2

$\mathrm{FW}$

FC

FF

FS

FL

FFBE

F T

F R

KIDS

INF

SIB

PLURAL

WIVES

INTERCEPT

6.04830

33.80400

1232.30000

0.09097

0.06960

0.70269

0.03968

0.08730

0.24908

9.22410

0.84005

0.02198

0.07936

0.05250

0.15140

0.08791

0.06349

0.07082

0.08547

0.16239

0.10379

0.02686

0.09402

6.28860

66.31700
4478.00000

0.06960

0.12332

0.74359

0.01709

0.04640

0.32357

23.14200

0.84127

14.66900

1.31620

13.26300

2. 67520

1.90230

R2

$\mathrm{N}$

$r$

0.0054

1638

\section{STANDARD}

DEVIATION

0.79167

9.46890

764.68000

0.28765

0.25454

0.45722

0.19527

0.28236

0.43261

8.13820

0.36667

0.14666

0.27039

0.22311

0.35855

0.28325

0.24392

0.25660

0.27967

0.36892

0.30507

0.16173

0.29194

0.98115

8.94610

1230.30000

0.25454

0.32891

0.43678

0.12966

0.21041

0.46798

13.76200

0.36554

8.23390

1.91230

6.98010

1.60620

1.19870

\author{
EST IMATED \\ COEFFICIEN T \\ STANDARD \\ ERROR
}

T-RAT IO

1632 DF

$$
\begin{array}{rrr}
0.12760 & 0.14616 & 0.87303 \\
0.08562 & 0.09404 & 0.91048 \\
0.06189 & 0.10628 & 0.58230 \\
0.07734 & 0.08100 & 0.95473 \\
0.20206 & 0.09152 & 2.20770 \\
0.04404 & 0.10021 & 0.43948 \\
0.11255 & 0.09707 & 1.15950 \\
0.06901 & 0.09220 & 0.74855 \\
-0.10290 & 0.07995 & -1.28720 \\
-0.03015 & 0.08783 & -0.34330 \\
-0.05936 & 0.13496 & -0.43982
\end{array}
$$

6.0107

0.06362

94.476

0.11989

0.02402

4. 991 
TABLE A. 9 (Cont'd)

REGRESSIONS AND INTRA-CLASS CORRELATIONS FOR INCOME OF BROTHERS

(WITH FATHER'S CHARACTERISTICS)

EQUATION 2

\begin{tabular}{|c|c|c|c|c|c|}
\hline $\begin{array}{l}\text { VARIABLE } \\
\text { NAME }\end{array}$ & MEAN & $\begin{array}{l}\text { STANDARD } \\
\text { DEVIATION }\end{array}$ & $\begin{array}{l}\text { EST IMATED } \\
\text { COEFFICIENT }\end{array}$ & $\begin{array}{l}\text { STANDARD } \\
\text { ERROR }\end{array}$ & $\begin{array}{l}\text { T-RATIO } \\
1632 \text { DF }\end{array}$ \\
\hline LN INCOME & 6.04830 & 0.79167 & & & \\
\hline AGE & 33.80400 & 9.46890 & 0.05779 & 0.00950 & 6.08580 \\
\hline AGE2 & 1232.30000 & 764.68000 & -0.00044 & 0.00012 & -3.77860 \\
\hline W & 0.09097 & 0.28765 & & & \\
\hline C & 0.06960 & 0.25454 & & & \\
\hline F & 0.70269 & 0.45722 & & & \\
\hline S & 0.03968 & 0.19527 & & & \\
\hline $\mathrm{L}$ & 0.08730 & 0.28236 & & & \\
\hline F B E & 0.24908 & 0.43261 & & & \\
\hline $\mathrm{T}$ & 9.22410 & 8.13820 & & & \\
\hline $\mathrm{R}$ & 0.84005 & 0.36667 & & & \\
\hline D 55 & 0.02198 & 0.14666 & 0.44293 & 0.14414 & 3.07290 \\
\hline D 57 & 0.07936 & 0.27039 & 0.42330 & 0.09601 & 4.40890 \\
\hline D 59 & 0.05250 & 0.22311 & 0.41143 & 0.10759 & 3.82410 \\
\hline D 61 & 0.15140 & 0.35855 & 0.38441 & 0.08318 & 4.62140 \\
\hline D 66 & 0.08791 & 0.28325 & 0.35967 & 0.08977 & 4.00670 \\
\hline D 70 & 0.06349 & 0.24392 & 0.15851 & 0.09 .747 & 1.62620 \\
\hline D 75 & 0.07082 & 0.25660 & 0.26195 & 0.09477 & 2.76420 \\
\hline D 80 & 0.08547 & 0.27967 & 0.15723 & 0.08961 & 1.75470 \\
\hline D 85 & 0.16239 & 0.36892 & 0.06372 & 0.07873 & 0.80933 \\
\hline D 90 & 0.10379 & 0.30507 & 0.07284 & 0.08538 & 0.85303 \\
\hline D 95 & 0.02686 & 0.16173 & -0.10709 & 0.13105 & -0.81720 \\
\hline DOO & 0.09402 & 0.29194 & & & \\
\hline LNFINCOME & E $\quad 6.28860$ & 0.98115 & & & \\
\hline FAGE & 66.31700 & 8.94610 & & & \\
\hline F AGE2 & 4478.00000 & 1230.30000 & & & \\
\hline F W & 0.06960 & 0.25454 & & & \\
\hline $\mathrm{FC}$ & 0.12332 & 0.32891 & & & \\
\hline $\mathrm{FS}$ & 0.01709 & 0.12966 & & & \\
\hline FL & 0.04640 & 0.21041 & & & \\
\hline FF BE & 0.32357 & 0.46798 & & & \\
\hline $\mathrm{FT}$ & 23.14200 & 13.76200 & & & \\
\hline $\mathrm{FR}$ & 0.84127 & 0.36554 & & & \\
\hline KIDS & 14.66900 & 8.23390 & & & \\
\hline INF & 1.31620 & 1.91230 & & & \\
\hline SIB & 13.26300 & 6.98010 & & & \\
\hline PLURAL & 2.67520 & 1.60620 & & & \\
\hline WIVES & 1.90230 & 1.19870 & & & \\
\hline $\mathrm{FF}$ & 0.74359 & 0.43678 & & & \\
\hline INTERCEPT & & & 4.4201 & 0.20681 & 21.372 \\
\hline $\mathrm{R} 2$ & 0.0718 & & & & \\
\hline $\begin{array}{l}\mathrm{N} \\
r\end{array}$ & & & 0 16700 & 002386 & $7 \cap \cap 4$ \\
\hline
\end{tabular}


TABLE A. 9 (Cont'd)

\section{REGRESSIONS AND INTRA-CLASS CORRELATIONS FOR INCOME OF BROTHERS \\ (WITH FATHER'S CHARACTERISTICS)}

\section{EQUATION 3}

\begin{tabular}{|c|c|c|c|c|c|}
\hline VARIABLE & MEAN & STANDARD & ESTIMATED & $\begin{array}{l}\text { STANDARD } \\
\text { ERROR }\end{array}$ & $\begin{array}{l}\text { T-RATIO } \\
1632\end{array}$ \\
\hline NAME & & DEVIATION & & & \\
\hline L N INC OME & 6.04830 & 0.79167 & & & \\
\hline$A^{\prime} G E$ & 33.80400 & 9.46890 & 0.05080 & 0.01040 & 4.88620 \\
\hline$\hat{A} G \bar{E} 2$ & 1232.30000 & 764.68000 & -0.00044 & 0.00012 & -3.74870 \\
\hline W & 0.09097 & 0.28765 & & & \\
\hline $\mathrm{C}$ & 0.06960 & 0.25454 & & & \\
\hline $\mathrm{F}$ & 0.70269 & 0.45722 & & & \\
\hline$S$ & 0.03968 & 0.19527 & & & \\
\hline $\mathrm{L}$ & 0.08730 & 0.28236 & & & \\
\hline D 55 & 0.02198 & 0.14666 & 0.51140 & 0.14403 & 3.55060 \\
\hline D 57 & 0.07936 & 0.27039 & 0.41025 & 0.09724 & 4.21910 \\
\hline D 59 & 0.05250 & 0.22311 & 0.41859 & 0.10840 & 3.86140 \\
\hline D 61 & 0.15140 & $0.3585 b$ & 0.41430 & 0.08405 & 4.92930 \\
\hline D 66 & 0.08791 & 0.28325 & 0.39044 & 0.08976 & 4.34970 \\
\hline D 70 & 0.06349 & 0.24392 & 0.21721 & 0.09842 & 2.20710 \\
\hline D 75 & 0.07082 & 0.25660 & 0.29965 & 0.09450 & 3.17100 \\
\hline D 80 & 0.08547 & 0.27967 & 0.15905 & 0.08951 & 1.77690 \\
\hline D 85 & 0.16239 & 0.36892 & 0.14744 & 0.08012 & 1.84020 \\
\hline D 90 & 0.10379 & 0.30507 & 0.14980 & 0.08589 & 1.74410 \\
\hline D 95 & 0.02686 & 0.16173 & -0.08735 & 0.13015 & -0.67114 \\
\hline $\mathrm{T}$ & 9.22410 & 8.13820 & 0.01082 & 0.00386 & 2.80000 \\
\hline $\mathrm{R}$ & 0.84005 & 0.36667 & -0.31549 & 0.05362 & -5.88420 \\
\hline F BE & 0.24908 & 0.43261 & 0.02468 & 0.04496 & 0.54905 \\
\hline $\mathrm{D} 00$ & 0.09402 & 0.29194 & & & \\
\hline LNF INCOME & 6.28860 & 0.98115 & & & \\
\hline F AGE & 66.31700 & 8.94610 & & & \\
\hline FAGE2 & 4478.00000 & 1230.30000 & & & \\
\hline FW & 0.06960 & 0.25454 & & & \\
\hline FC & 0.12332 & 0.32891 & & & \\
\hline FS & 0.01709 & 0.12966 & & & \\
\hline FL & 0.04640 & 0.21041 & & & \\
\hline FFBE & 0.32357 & 0.46798 & & & \\
\hline $\mathrm{FT}$ & 23.14200 & 13.76200 & & & \\
\hline FR & 0.84127 & 0.36554 & & & \\
\hline KIDS & 14.66900 & 8.23390 & & & \\
\hline INF & 1.31620 & 1.91230 & & & \\
\hline SIB & 13.26300 & 6.98010 & & & \\
\hline PLURAL & 2.67520 & 1.60620 & & & \\
\hline WIVES & 1.90230 & 1.19870 & & & \\
\hline F F & 0.74359 & 0.43678 & & & \\
\hline INTERCEPT & & & 4.7839 & 0.21995 & 21.750 \\
\hline $\begin{array}{l}\mathrm{R} 2 \\
\mathrm{~N}\end{array}$ & 1638.0931 & & & & \\
\hline$r$ & & & 0.15238 & 0.02391 & 6.372 \\
\hline
\end{tabular}


TABLEA. 9 (Cont'd)

REGRESSIONS AND INTRA-CLASS CORRELATIONS FOR

INCOME OF BROTHERS

(WITH FATHER'S CHARACTERISTICS)

\section{EQUATION 4}

\begin{tabular}{|c|c|c|c|c|c|}
\hline $\begin{array}{l}\text { VAR IABLE } \\
\text { NAME }\end{array}$ & ME AN & $\begin{array}{l}\text { STANDARD } \\
\text { DEVIATION }\end{array}$ & $\begin{array}{l}\text { EST IMATED } \\
\text { COEFF ICIENT }\end{array}$ & $\begin{array}{l}\text { STANDARD } \\
\text { ERROR }\end{array}$ & $\begin{array}{l}\text { T-RATIO } \\
1632 \text { DF }\end{array}$ \\
\hline LN INCOME & 6.04830 & 0.79167 & & & \\
\hline AGE & 33.80400 & 9.46890 & 0.05172 & 0.01015 & 5.09670 \\
\hline AGE2 & 1232.30000 & 764.68000 & -0.00041 & 0.00012 & -3.56440 \\
\hline $\bar{D} 5 \overline{5}$ & 0.02198 & 0.14666 & 0.65908 & 0.14158 & 4.65500 \\
\hline D 57 & 0.07936 & 0.27039 & 0.58946 & 0.09670 & 6.09600 \\
\hline D5 9 & 0.05250 & 0.22311 & 0.59166 & 0.10721 & 5.51880 \\
\hline D 61 & 0.15140 & 0.35855 & 0.58329 & 0.08397 & 6.94640 \\
\hline D 66 & 0.08791 & 0.28325 & 0.52915 & 0.08874 & 5.96290 \\
\hline D 70 & 0.06349 & 0.24392 & 0.29818 & 0.09642 & 3.09240 \\
\hline D 75 & 0.07082 & 0.25660 & 0.37312 & 0.09256 & 4.03130 \\
\hline D 80 & 0.08547 & 0.27967 & 0.24988 & 0.08816 & 2.83440 \\
\hline D 85 & 0.16239 & 0.36892 & 0.18922 & 0.07806 & 2.42400 \\
\hline D 90 & 0.10379 & 0.30507 & 0.22720 & 0.08395 & 2.70650 \\
\hline D 95 & 0.02686 & 0.16173 & -0.02047 & 0.12703 & -0.16117 \\
\hline D 00 & 0.09402 & 0.29194 & & & \\
\hline $\mathrm{T}$ & 9.22410 & 8.13820 & 0.00990 & 0.00375 & 2.64210 \\
\hline $\mathrm{R}$ & 0.84005 & 0.36667 & -0.29588 & 0.05291 & -5.59240 \\
\hline FBE & 0.24908 & 0.43261 & 0.03484 & 0.04393 & 0.79307 \\
\hline W & 0.09097 & 0.28765 & 0.60794 & 0.06740 & 9.02000 \\
\hline C & 0.06960 & 0.25454 & -0.00213 & 20.0729 & -0.29256 \\
\hline $\mathrm{F}$ & 0.70269 & 0.45722 & & & \\
\hline$S$ & 0.03968 & 0.19527 & -0.14266 & 0.09519 & -1.49870 \\
\hline $\mathrm{L}$ & 0.08730 & 0.28236 & -0.24648 & 0.06585 & -3.74300 \\
\hline LNF INCOME & 6.28860 & 0.98115 & & & \\
\hline FAGE & 66.31700 & 8.94610 & & & \\
\hline FAGE2 & 4478.00000 & 1230.30000 & & & \\
\hline FT & 23.14200 & 13.76200 & & & \\
\hline$F \mathrm{R}$ & 0.84127 & 0.36554 & & & \\
\hline FFBE & 0.32357 & 0.46798 & & & \\
\hline $\mathrm{FW}$ & 0.06960 & 0.25454 & & & \\
\hline FC & 0.12332 & 0.32891 & & & \\
\hline FF & 0.74359 & 0.43678 & & & \\
\hline FS & 0.01709 & 0.12966 & & & \\
\hline FL & 0.04640 & 0.21041 & & & \\
\hline KIDS & 14.66900 & 8.23390 & & & \\
\hline INF & 1.31620 & 1.91230 & & & \\
\hline SIB & 13.26300 & 6.98010 & & & \\
\hline PLURAL & 2.67520 & 1.60620 & & & \\
\hline WIVES & 1.90230 & 1.19870 & & & \\
\hline INTERCEPT & & & 4.5755 & 0.21968 & 20.828 \\
\hline $\mathrm{R} 2$ & 0.1488 & & & & \\
\hline N & & & & & \\
\hline$r$ & & & 0.13756 & 0.02397 & 5.740 \\
\hline
\end{tabular}


TABLE A. 10

REGRESSIONS AND INTRA-CLASS CORRELATIONS FOR

WEALTH OF BROTHERS

(WITH FATHER'S CHARACTERISTICS )

EQUATION 1

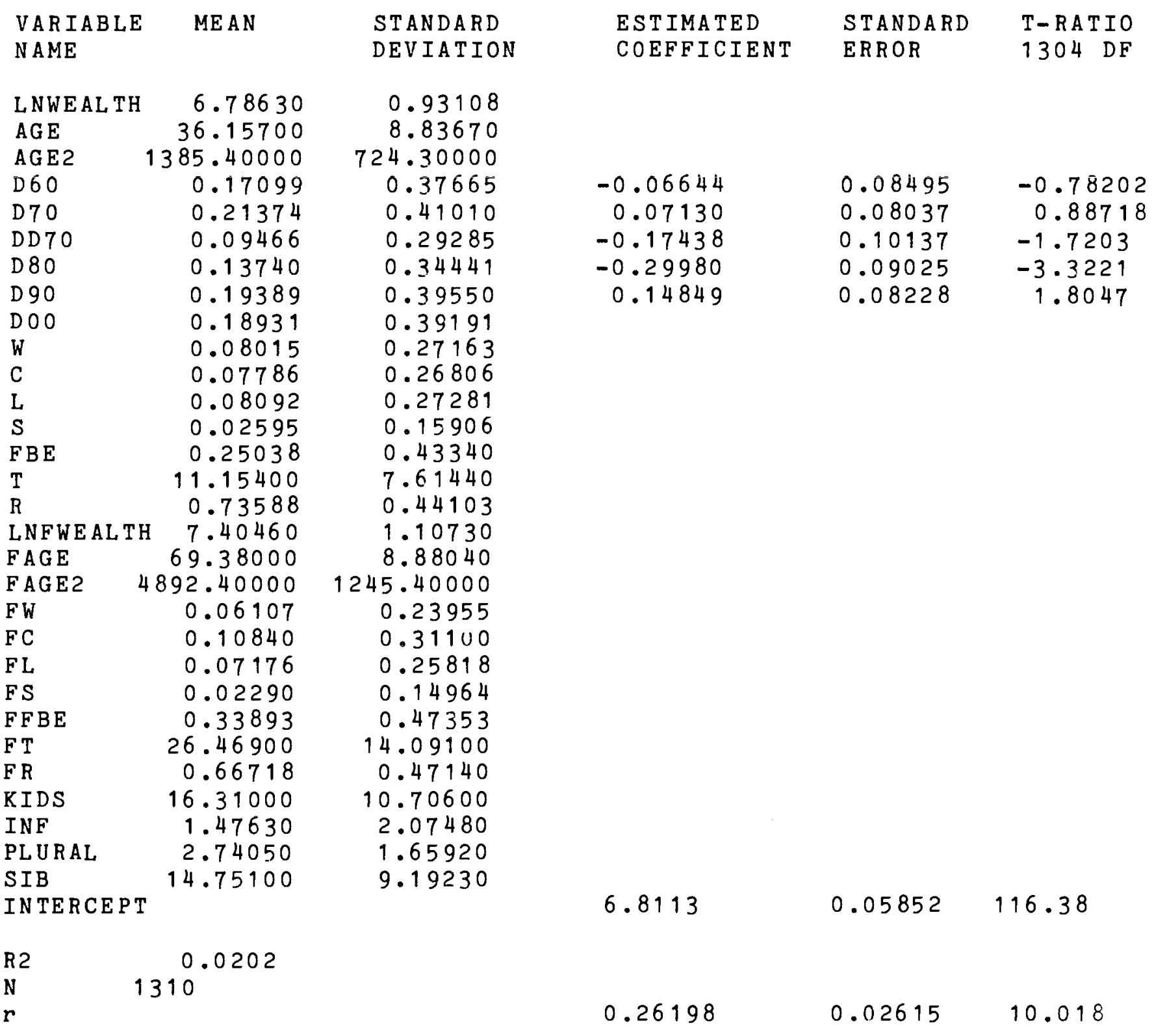


TABLE A. 10 (Cont'd)

\section{REGRESSIONS AND INTRA-CLASS CORRELATIONS FOR WEALTH OF BROTHERS \\ (WITH FATHER'S CHARACTERISTICS )}

EQUATION 2

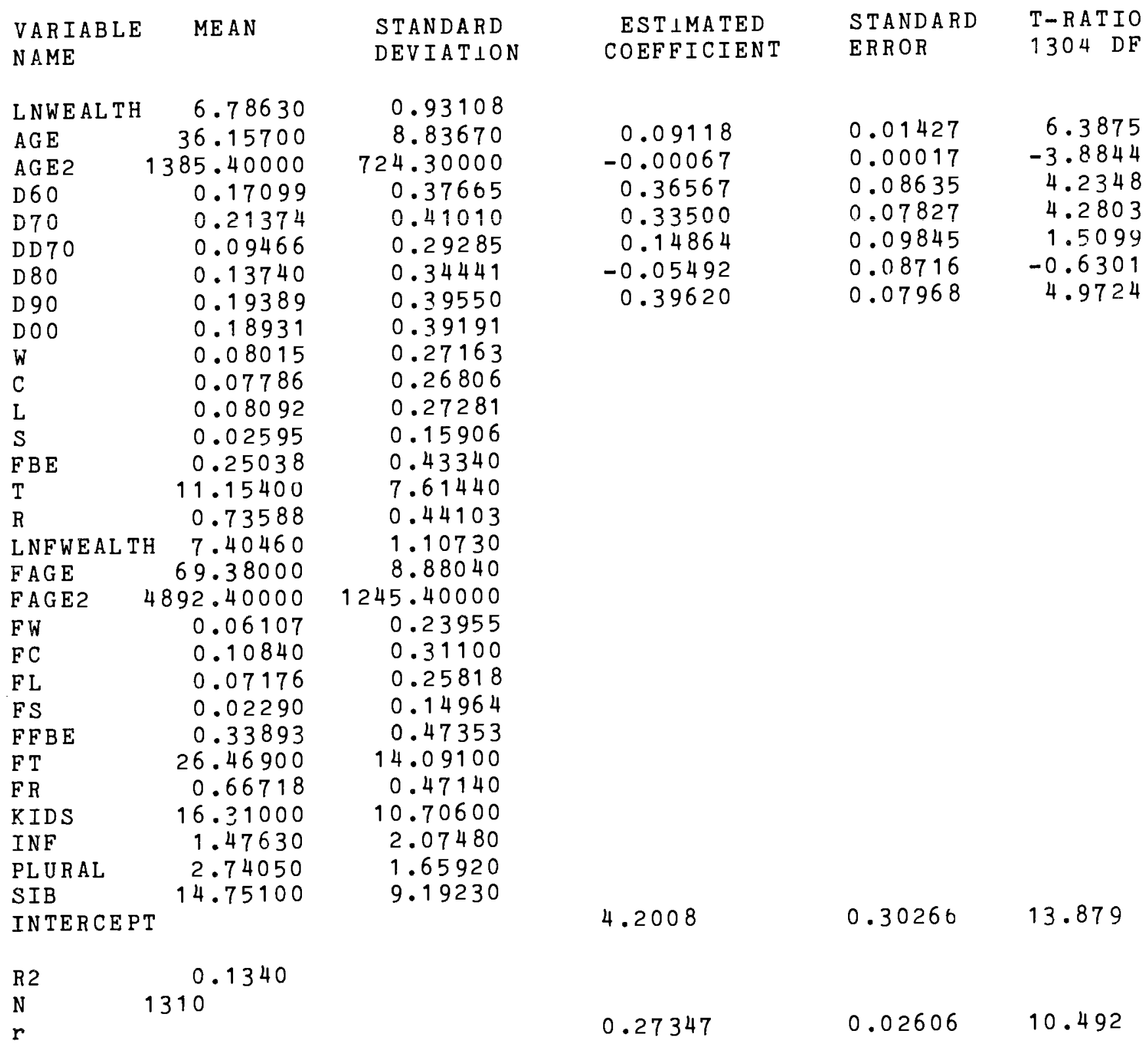


TABLE A. 10 (Cont'd)

REGRESSIONS AND INTRA-CLASS CORRELATIONS FOR WEALTH OF BROTHERS

(WITH FATHER'S CHARACTERISTICS )

EQUATION 3

\begin{tabular}{|c|c|c|c|c|c|}
\hline VAR IABLI & MEAN & STANDARD & ESTIMATED & STANDARD & T-RATIO \\
\hline NAME & & DEVIATION & COEFFICIENT & ERROR & $1304 \mathrm{DF}$ \\
\hline LNWEALTF & 6.78630 & 0.93108 & & & \\
\hline AGE & 36.15700 & 8.83670 & 0.08294 & 0.01461 & 5.6766 \\
\hline AGE2 & 1385.40000 & 724.30000 & -0.00061 & 0.00017 & -3.5512 \\
\hline D 60 & 0.17099 & 0.37665 & 0.44991 & 0.08841 & 5.0890 \\
\hline D 70 & 0.21374 & 0.41010 & 0.42220 & 0.07916 & 5.3332 \\
\hline D D 70 & 0.09466 & 0.29285 & 0.19465 & 0.09827 & 1.9809 \\
\hline D 80 & 0.13740 & 0.34441 & -0.03504 & 0.08653 & -0.4050 \\
\hline D 90 & 0.19389 & 0.39550 & 0.46787 & 0.08066 & 5.8004 \\
\hline DOO & 0.18931 & 0.39191 & & & \\
\hline$W$ & 0.08015 & 0.27163 & & & \\
\hline C & 0.07786 & 0.26806 & & & \\
\hline L & 0.08092 & 0.27281 & & & \\
\hline$S$ & 0.02595 & 0.15906 & & & \\
\hline FBE & 0.25038 & 0.43340 & -0.10222 & 0.05618 & -1.8193 \\
\hline $\mathrm{T}$ & 11.15400 & 7.61440 & 0.01124 & 0.00383 & 2.9353 \\
\hline $\mathrm{R}$ & 0.73588 & 0.44103 & -0.27087 & 0.05477 & -4.9454 \\
\hline LNFWEALI & 7.40460 & 1.10730 & & & \\
\hline FAGE & 69.38000 & 8.88040 & & & \\
\hline FAGE2 & 4892.40000 & 1245.40000 & & & \\
\hline $\mathrm{FW}$ & 0.06107 & 0.23955 & & & \\
\hline $\mathrm{FC}$ & 0.10840 & 0.31100 & & & \\
\hline FL & 0.07176 & 0.25818 & & & \\
\hline FS & 0.02290 & 0.14964 & & & \\
\hline FFBE & 0.33893 & 0.47353 & & & \\
\hline FT & 26.46900 & 14.09100 & & & \\
\hline FR & 0.66718 & 0.47140 & & & \\
\hline KIDS & $16 \cdot 31000$ & 10.70600 & & & \\
\hline INF & 1.47630 & 2.07480 & & & \\
\hline PLURAL & 2.74050 & 1.65920 & & & \\
\hline $\begin{array}{l}\text { SIB } \\
\text { IIt }\end{array}$ & 14.75100 & 9.19230 & & & \\
\hline INTERCEP & & & 4.4658 & 0.30485 & $14.04 y$ \\
\hline $\mathrm{R} 2$ & 0.1544 & & & & \\
\hline N & & & & & \\
\hline N1 & & & 025632 & 0 & 0786 \\
\hline & & & 20כל & $0.0<17$ & 9.100 \\
\hline
\end{tabular}


TABLE A. 10 (Cont'd)

REGRESSIONS AND INTRA-CLASS CORRELATIONS FOR

WEALTH OF BROTHERS

(WITH FATHER'S CHARACTERISTICS )

EQUATION 4

\begin{tabular}{|c|c|c|c|c|c|}
\hline $\begin{array}{l}\text { VARIABLE } \\
\text { NAME }\end{array}$ & MEAN & $\begin{array}{l}\text { STANDARD } \\
\text { DEVIATION }\end{array}$ & $\begin{array}{l}\text { ESTIMATED } \\
\text { COEFFICIENT }\end{array}$ & $\begin{array}{l}\text { STANDARD } \\
\text { ERROR }\end{array}$ & $\begin{array}{l}\text { T-RATIO } \\
1304 \text { DF }\end{array}$ \\
\hline LNWEALTH & 6.78630 & 0.93108 & & & \\
\hline$A G E$ & 36.15700 & 8.83670 & 0.08029 & 0.01408 & 5.7010 \\
\hline$A G E 2$ & 1385.40000 & 724.30000 & -0.00057 & 0.00017 & -3.4237 \\
\hline D 60 & 0.17099 & 0.37665 & 0.57134 & 0.08558 & 6.6757 \\
\hline D 70 & 0.21374 & 0.41010 & 0.50236 & 0.07633 & 6.5816 \\
\hline DD 70 & 0.09466 & 0.29285 & 0.26251 & 0.09466 & 2.7732 \\
\hline D 80 & 0.13740 & 0.34441 & 0.02812 & 0.08393 & 0.3350 \\
\hline D90 & 0.19389 & 0.39550 & 0.46922 & 0.07738 & 6.0640 \\
\hline DOO & 0.18931 & 0.39191 & & & \\
\hline$W$ & 0.08015 & 0.27163 & 0.61590 & 0.08802 & 6.9976 \\
\hline $\mathrm{C}$ & 0.07786 & 0.26806 & -0.45886 & 0.08636 & -5.3130 \\
\hline $\mathrm{L}$ & 0.08092 & 0.27281 & -0.46300 & 0.08456 & -5.4757 \\
\hline$S$ & 0.02595 & 0.15906 & -0.34295 & 0.14635 & -2.3434 \\
\hline F BE & 0.25038 & 0.43340 & -0.05669 & 0.05444 & -1.0412 \\
\hline $\mathrm{T}$ & 11.15400 & 7.61440 & 0.01224 & 0.00367 & 3.3352 \\
\hline $\mathrm{R}$ & 0.73588 & 0.44103 & -0.23618 & 0.05367 & -4.4004 \\
\hline LNFWEALTH & 7.40460 & 1.10730 & & & \\
\hline F A GE & 69.38000 & 8.88040 & & & \\
\hline FAGE2 & 4892.40000 & 1245.40000 & & & \\
\hline F W & 0.06107 & 0.23955 & & & \\
\hline FC & 0.10840 & 0.31100 & & & \\
\hline FL & 0.07176 & 0.25818 & & & \\
\hline $\mathrm{FS}$ & 0.02290 & 0.14964 & & & \\
\hline FF BE & 0.33893 & 0.47353 & & & \\
\hline $\mathrm{FT}$ & 26.46900 & 14.09100 & & & \\
\hline F R & 0.66718 & 0.47140 & & & \\
\hline KIDS & 16.31000 & 10.70600 & & & \\
\hline INF & 1.47630 & 2.07480 & & & \\
\hline PLURAL & 2.74050 & 1.65920 & & & \\
\hline SIB & 14.75100 & 9.19230 & & & \\
\hline INTERCEPT & & & 4.4310 & 0.29545 & 14.997 \\
\hline $\mathrm{R} 2$ & 0.2257 & & & & \\
\hline $\mathrm{N}$ & 1310 & & & & \\
\hline$r$ & & & 0.22653 & 0.02639 & 8.583 \\
\hline
\end{tabular}


TABLE A. 10 (Cont'd)

REGRESSIONS AND INTRA-CLASS CORRELATIONS FOR WEALTH OF BROTHERS

(WITH FATHER'S CHARACTERISTICS )

EQUATION 5

\section{VARIABLE MEAN} NAME

LNWEALTH
AGE
AGE2
D 60
D 70
DD 70
D 80
D 90
D O 0
W
C
L
S
FBE
T
R

LNFWEALTH

\section{FAGE}

FAGE2

FW

FC

FL

FS

FFBE

FT

FR

KIDS

INF

PLURAL

SIB

IN TERCEPT
STANDARD

DEV IATION

0.93108

8.83670

724.30000

0.37665

0.41010

0.29285

0.34441

0.39550

0.39191

0.27163

0.26806

0.27281

0.15906

0.43340

7.61440

0.44103

1.10730

8.88040

1245.40000

0.23955

0.31100

0.25818

0.14964

0.47353

14.09100

0.47140

10.70600

2.07480

1.65920

9.19230

\section{ES T IMATED}

COEFFICIENT

0.08734

$-0.00062$

0.96979

0.79584

0.61668

0.26166

0.54553

0.45781

$-0.49574$

$-0.47137$

$-0.37704$

$-0.14827$

0.01225

$-0.13078$

$-0.00363$

0.31219

0.08487

0.25060

$-0.31589$

0.11379

0.01045

$-0.10890$

$-0.00287$

$-0.00343$

4.0238
STANDARD

ERROR

0.01454

0.00017

0.24239

0.18474

0.19732

0.14437

0.09865

0.10013

0.08915

0.08468

0.14623

0.08262

0.00376

0.06503

0.00351

0.12144

0.08183

0.09252

0.15547

0.07886

0.00603

0.06246

0.01572

0.00346

0.44917
T- RAT IO 1304 DF

6.0069

$-3.6649$

4.0009

4.3079

3.1253

1.8125

5.5297

4.5721

$-5.5606$

$-5.5666$

$-2.5784$

$-1.7945$

3.2550

$-2.0109$

$-1.0327$

2. 5707

1.0371

2.7088

$-2.0318$

1.4429

1.7328

$-1.7434$

$-0.18240$

$-0.99154$

8.9581
R2
N
0.2381
$r$
1310

0.20694

0.02651

7.806 
TABLE A. 10 (Cont'd)

REGRESSIONS AND INTRA-CLASS CORRELATIONS FOR WEALTH OF BROTHERS

(WITH FATHER'S CHARACTERISTICS )

EQUATION 6

\begin{tabular}{|c|c|c|c|c|c|}
\hline \multirow{2}{*}{$\begin{array}{l}\text { VAR IABLE } \\
\text { NAME }\end{array}$} & \multirow[t]{2}{*}{ MEAN } & \multirow{2}{*}{$\begin{array}{l}\text { STANDARD } \\
\text { DEVIATION }\end{array}$} & \multirow{2}{*}{$\begin{array}{l}\text { EST IMATED } \\
\text { COEFFICIENT }\end{array}$} & \multirow{2}{*}{$\begin{array}{l}\text { STANDARD } \\
\text { ERROR }\end{array}$} & \multirow{2}{*}{$\begin{array}{l}\text { T-RATIO } \\
1304 \text { DF }\end{array}$} \\
\hline & & & & & \\
\hline LNWEAL TH & 6.78630 & 0.93108 & & & \\
\hline $\mathrm{AGE}$ & 36.15700 & 8.83670 & 0.08591 & 0.01436 & 5.9823 \\
\hline AGE2 & 1385.40000 & 724.30000 & -0.00060 & 0.00017 & -3.5754 \\
\hline D 60 & 0.17099 & 0.37665 & 0.82979 & 0.24055 & 3.4496 \\
\hline D 70 & 0.21374 & 0.41010 & 0.67389 & 0.18362 & 3.6701 \\
\hline DD 70 & 0.09466 & 0.29285 & 0.51698 & 0.19559 & 2.6432 \\
\hline D 80 & 0.13740 & 0.34441 & 0.17613 & 0.14331 & 1.2290 \\
\hline D 90 & 0.19389 & 0.39550 & 0.46236 & 0.09846 & 4.6961 \\
\hline D 00 & 0.18931 & 0.39191 & & & \\
\hline$W$ & 0.08015 & 0.27163 & 0.41233 & 0.09918 & 4.1573 \\
\hline C & 0.07786 & 0.26806 & -0.50086 & 0.08804 & -5.6893 \\
\hline L & 0.08092 & 0.27281 & -0.44551 & 0.08373 & -5.3206 \\
\hline$S$ & 0.02595 & 0.15906 & -0.40195 & 0.14446 & -2.7825 \\
\hline F BE & 0.25038 & 0.43340 & -0.15560 & 0.08160 & -1.9070 \\
\hline $\mathrm{T}$ & 11.15400 & 7.61440 & 0.00893 & 0.00376 & 2.3755 \\
\hline $\mathrm{R}$ & 0.73588 & 0.44103 & -0.12439 & 0.06423 & -1.9367 \\
\hline LNFWEALTH & 7.40460 & 1.10730 & 0.15315 & 0.02630 & 5.8226 \\
\hline FAGE & 69.38000 & 8.88040 & 0.00319 & 0.00366 & 0.8704 \\
\hline FAGE2 & 4892.40000 & 1245.40000 & & & \\
\hline $\mathrm{FW}$ & 0.06107 & 0.23955 & 0.24407 & 0.12049 & 2.0257 \\
\hline FC & 0.10840 & 0.31100 & 0.05767 & 0.08094 & 0.7125 \\
\hline FL & 0.07176 & 0.25818 & 0.21712 & 0.09153 & 2.3720 \\
\hline FS & 0.02290 & 0.14964 & -0.31629 & 0.15352 & -2.0602 \\
\hline FFBE & 0.33893 & 0.47353 & 0.17901 & 0.07867 & 2.2755 \\
\hline $\mathrm{FT}$ & 26.46900 & 14.09100 & 0.00578 & 0.00601 & 0.9621 \\
\hline $\mathrm{FR}$ & 0.66718 & 0.47140 & -0.08845 & 0.06178 & -1.4317 \\
\hline SIB & 14.75100 & 9.19230 & -0.01122 & 0.00367 & -3.0573 \\
\hline PLURAL & 2.74050 & 1.65920 & 0.00479 & 0.01557 & 0.3078 \\
\hline KIDS & $16 \cdot 31000$ & 10.70600 & & & \\
\hline INF & 1.47630 & 2.07480 & & & \\
\hline INTERCEPT & & & 2.7530 & 0.49432 & 5.5694 \\
\hline R2 & 0.2571 & & & & \\
\hline N & 1310 & & 0.19393 & 0.02658 & 7.296 \\
\hline$r$ & & & 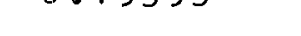 & & \\
\hline
\end{tabular}

